\title{
Kemâleddin Harputî Efendi’nin Şiirleri
}

\author{
Doç. Dr. Ahmet KARATAŞ
}

\begin{abstract}
Öz: Osmanlı’nın son devir âlimlerinden olan Mehmed Kemâleddin Efendi, Harput'un asırlarca ulemâ ve müftü yetiştiren İmâmzâde/ Efendigil âilesinin dinî eserler yazan son ferdidir. $\mathrm{O}$ da dedeleri gibi uzun yıllar hem müderrislik hem de müftülük yapmıştır. Harput'ta "Müftü Kemâl Efendi” olarak anılan Mehmed Kemâleddin Efendi’nin dinî, ahlâkî ve tasavvufî mensur eserlerinin yanında bir kısmı çeşitli yazma mecmualarda dağınık hâlde bulunan, bir kısmı da devrin gazetelerinde neşredilen şiirleri mevcuttur. Kemâleddin Efendi 1926'da El'aziz müftüsüyken evinde hilâfetin kaldırılmasını, şapka takmak başta olmak üzere inkılâpları ve "hükûmet-i milliyye"yi tenkid eden evrâk tespit edilmesi üzerine Şark İstiklâl Mahkemesi’nde yargılanıp Samsun’a sürgün edilince șiirlerini bir araya getirme imkânı bulamamış, bunların bir kısmı o hengâmede zâyi olmuştur. Kemâleddin Efendi’nin tutuklanıp yargılanmasına, azil ve sürgüne mahkûm edilmesine sebep olan “te’sîri hâvî” gazeli başta olmak üzere gün yüzüne çıkmamış şiirleri tarafımızdan tespit edilmiş, gazetelerde neşredilenlerle birlikte belli bir tasnifle ve gerekli yerlerde çeşitli açıklamalar ilâve edilerek bu makale vâsıtasıyla ilim âleminin istifâdesine sunulmuştur.
\end{abstract}

Anahtar Kelimeler: Harput, El'aziz, Müftü Kemâleddin Harputî, şiir, Şark İstiklâl Mahkemesi.

\section{Kemaleddin Harputi's Poems}

Abstract: Mehmed Kemâleddin Efendi, one of the last scholars in the Ottoman Empire, is the last person of İmamzade/Efendigil family, which brought up muftis and scholars. He was a writer of religious books. Like his ancestors before him, he was mufti and mudarris. He was called "Mufti Kemal Efendi" in Harput. He has religious, ethical and sufi prosaic books. In addition, he has written poems that have been published in manuscript documents and in some newspapers. When he was mufti of El'aziz in 1926, Kemaleddin Efendi was convicted in The Eastern Courts of Independence (Şark İstiklal Court) and exiled to Samsun after papers of his containing criticism regarding revolutionary movements which abolished the Caliphate System and made hats an obligatory item in one's attire were found. Because of this, he was not able to collect his poems and some of his poems were gone to waste. I came upon his lyric poem, which is the culprit to his exile. I also came upon some of his poems which have never been found anywhere, and added to them poems which were published in newspapers. In addition, I added explanations to some parts.

Key Words: Harput, El'aziz, Mufti Kemâleddin Harputî, poem, The Eastern Courts of Independence.

* Marmara Üniversitesi İlâhiyat Fakültesi Türk-İslâm Edebiyatı Anabilim Dalı Öğretim Üyesi. E-posta: karatasahmed@gmail.com

Makaleyi baştan sona büyük bir ihtimâmla okuyup değerlendirme lutfunda bulunan muhterem hocam Prof. Dr. Mustafa Tahralıya ve azîz dostum, kıymetli meslektaşım Yrd. Doç. Dr. Kenan Özçelik̉e şükrân ve minnet boçluyum. 
Mehmed Kemâleddin Efendi (v. 1354/1936) Ma'mûretü'l-azîz (El'azîz/Elazığ)'in Osmanlı'daki son, Cumhuriyet'teki ilk müftüsü olup kuşaktan kuşağa intikāl eden bir ilim silsilesinin dinî eserler veren son halkasıdır. Babasının yanında aldığı güçlü bir medrese eğitiminden sonra El'aziz' in çeşitli mekteplerinde muallimlik, Harput Kâmil Paşa Medresesi ve Dârü'l-hilâfeti'l-'aliyye'de müderrislik, Harput İmam Hatip Mektebi’nde hocalık yapmıştır. El'azîz Vilâyet müftülügü ise 1916-1926 yılları arasına rastlar. Kemâleddin Efendi aşağıda anlatacağımız hususlar yüzünden Şark İstiklâl Mahkeme’sinin kararı ile önce tutuklanmış, sonra yargılanarak 4 Eylül 1926'da müftülükten azledilmiş ve Samsun'a sürgüne gönderilmiştir. 2 yıl kadar süren yıpratıcı sürgün devresinden sonra Harput’a dönen Kemâleddin Efendi uzlete çekilmek zorunda kalmış, yakalandığı mesâne kanseri sebebiyle de 2 Şubat 1936'da 70 yaşındayken vefât etmiş ve Harput'taki âile mezarlığına defnedilmiştir. ${ }^{1}$

Kemâleddin Efendi, dedeleri ve babası gibi kuvvetli bir âlim, iyi bir müderris ve san'at kaygısı taşımayan bir edîptir. Dedesi “Kasîde-i Bürde Şârihi” olarak bilinen Harput Müftüsü Ömer Naîmî Efendi (v. 1299/1882) ve babası büyük âlim, müderris Abdülhamîd Hamdî Efendi (v. 1320/1902) gibi kendisi de zaman zaman çeşitli manzûmeler yazmış, bazı şiirleri döneminin mecmualarında yayımlanmıştır. ${ }^{2}$ Mensûr eserleri arasında Kasîde-i Münferice’nin Tahmîsiyle Berâber Türkçe Şerhidir, el-Mülemma' Şerhu'n-na'ti'l-murassa' bil-mücennesi'lmüsecca', Hadîs-i Erbaîn, Tesbîtü'l-mefhûm fî tahkikit-tebe 'iyyeti beyne’l-ilmi ve'l-ma'lûm, Kasîde-i Tantarâniyye, Kasîde-i Ferîde, Makāme-i Sûfiyye ve Levâmi-i Câmî tercümelerini sayabiliriz.

Kemâleddin Efendi’nin Ankara Üniversitesi İlâhiyat Fakültesi'ne intikāl eden kütüphânesindeki kitaplarını incelediğimizde onun bazı eserlerin sayfa kenarları ve boş varaklara çeşitli şâirlere âit yüzlerce Türkçe, Arapça, Farsça şiirler yazdığını gördük. Eserlerinin büyük bir kısmının çeşitli manzûmelerin tercümesi ve şerhinden ibâret olması onun şiire olan merakını göstermesi bakımından mühimdir. Kemâleddin Efendi’nin şiire merâkı bunlardan ibâret kalmamış, zaman zaman başta târih manzûmeleri olmak üzere nazîreler, tahmisler, kıt'alar, kasîde ve gazeller yazmıştır. Ancak bunları bir araya getirme fırsatı bulamamış, İbnülemîn merhûmun ifadelerine göre Samsun’a sürgüne gönderilme karmaşasında şiirlerinin çoğu zâyi olmuştur. ${ }^{3}$

Kemâleddin Efendi beyitler ve kıt'alarla dolu mecmualarda kendi şiirlerinin altına ekseriyetle imzâsını atmış veya "nâzımuhû, li-muharririhî, Kemâl, Kemâleddîn" gibi kayıtlar düşmüştür. Ancak, kendisine âit olduğu hâlde adını yazmadığı yahut imzâ atmadığı şiirleri de vardır. Bu sebeple başta beyit ve kıt'a olmak üzere mecmualara yazdığ yüzlerce imzâsız şiir arasından kendi şiirlerini ayırma hususunda zorlandık. Bir çok kaynaktan taramalar yaparak

1 Kemâleddin Efendỉnin hayatı, şahsiyeti ve eserleriyle ilgili teferruatlı bilgi için bk. Ahmet Karataş, "Harput Ulemâsından Müderris-Müftü Mehmed Kemâleddin Efendi", Marmara Üniversitesi İlâhiyat Fakültesi Dergisi, sy. 49 (İstanbul 2015), s. 29-125.

2 Dede Ömer Naîmî Efendỉnin en önemli manzûmeleri arasında bir nasîhatnâme olan Manzûme-i Na îmiyye (İstanbul 1283)'yi ve Şeyhülislâm Ârif Bey (v. 1275/1859) için yazdığı on fasıllık Arapça Dürer adlı kasîdesini sayabiliriz. Abdülhamîd Hamdî Efendi’nin ise İbnü’n-Nahvînnin (v. 513/1119) el-Kasîdetü’l-Münferice’sine yaptığı ve Kemâleddin Efendi tarafından şerhedilen tahmîsi (Ma'mûretü'l-'azîz 1317) önemlidir. Hem Ömer Naîmî hem de Abdülhamîd Hamdî Efendilerin kütüphânelerindeki yazmaları arasında Türkçe, Arapça ve Farsça yazılmış çeşitli şiirlerin dağınık bir şekilde bulunması Kemâleddin Efendi’ye sadece ilmî birikimin değil, güçlü bir edebî geleneğin de miras kaldığının işâretidir.

3 İbnülemîn Mahmud Kemâl İnal, Son Asır Türk Şâirleri, İstanbul 1988, II, 854. 
imzâsız şiirlerin şâirlerini bulup onları ayırdık. Geride kalanları Kemâleddin Efendi'nin diğer şiirleriyle mânâ, mefhum, san'at, üslup ve muhtevâ bakımından kıyaslayarak ona âidiyyetini tespit etmeye çalıştık. Binâenaleyh, şâirlerini bulamasak da Kemâleddin Efendi'nin şiir kudretini aşan, oldukça san'atlı beyit yahut mısrâ-ı berceste ve âzâdeleri; dinî kaygılardan uzak, elimizdeki şiirlerinin muhtevâsına uymayan manzûmeleri makalemize almadık. Böylelikle Kemâleddin Efendi’nin şimdilik 82 şiirini tespit edebildik. Bu şiirlerin büyük bir kısmına Kemâleddin Efendi'nin kütüphânesindeki eserlerde yaptığımız incelemeler ve yaşadığı dönemde yayımlanan gazete ve dergilerdeki taramalarımız neticesinde ulaştık. Bu süreli yayın taramasında Kemâleddin Efendi’nin şiirlerinin Beyânü'l-Hak, Cerîde-i Sûfiyye ve Hazîne-i Fünûn gazetelerinde neşredildiğini gördük. Bütün şiirlerin kaynaklarını ilgili yerlerde dipnot olarak gösterdik.

Kemâleddin Efendi'nin ulaşabildiğimiz şiirlerinden 5'i kasîde, 3'ü kısa manzûme, 12'si gazel, 5’i musammat, 36’sı kıt'a/ rubâ'î, 20’si müfred, 1'i mısrâdır. Bu şiirlerin 20'si târih manzûmesidir. ${ }^{4}$ Arapça ve Farsça'ya vâkıf olan ve bu dillerden yaptığı tercümeleri bulunan Kemâleddin Efendi'nin Arapça 4 şiirini tespit ettik, ancak Farsça şiirlerinin varlığı hakkında mâlûmat edinemedik.

İbnülemîn, Kemâleddin Efendi’nin Kasîde-i Münferice’nin Tahmîsiyle Berâber Türkçe Şerhidir adlı kitabına yazdı̆̆ı takrîzde onu "Üstâd-1 a'zam-1 edeb” ve "andelîb-i gülzâr-1 fesâhat" olarak tavsif etmekte, yazdıklarının da âriflerin kalplerini zevke getiren hoş kokulu cennet çiçekleri olduğunu söylemektedir: "Bir 'andelîb-i gülzâr-1 fesâhatdır ki icrâ etdiği terennümât-1 cezbe-âver erbâb-1 huşû bir vecd-i tâm ile nağme-perdâz-1 gülbâng-i 'Allâhu ekber' eder. Müellefât-1 ber-güzîdesi ki zehre-i gâliye-bâr-1 behiştî gibi zevk-resân-1 kulûb-1 'urefâdır..."5 Bununla birlikte o, Kemâleddin Efendi’nin "şâir" değil, "emsâli gibi nâzım" olduğu kanaatindedir. ${ }^{6}$ İbnülemîn’in "emsâl” kelimesinden kastı ilim erbâbı/ müderris olup şiir yazan zevâttır.

Şiirlerinde "Kemâl” ve "Kemâleddîn" mahlaslarını kullanan Kemâleddin Efendi’nin yer yer teknik açıdan kusurlu, mânâ itibâriyle zayıf beyitleri varsa da şiirleri ekseriyetle muhkem ve hikmet-âmizdir. Kemâleddin Efendi mutasavvıf bir âlim ve şâirdir. Binâenaleyh şiirlerinde his ve heyecânın yanında derin bir bilgi ve tasavvufî neşvenin izlerinin bulunması gayet tabiîdir. Bilhassa,

Resûl-i Kibriyâ’nın hulk-1 pâki 'ayn-1 Kur’ân'dır

Hadîs-i Hazret-i Sıddîk'a bu matlûbe burhândır

beytiyle başlayan na'tini, eslâfı olan şuarânın bu tarz şiirlerde gösterdikleri husûsî itinâ gibi, fevkalâde bir ihtimâmla yazarak âdetâ kendini aşmıştır:

Burâk u berkı geçdin âlem-i lâhûtı seyr etdin

Ve "mâ zâğe'l-basar"dan kasd-1 Kur'ân kadrin i'lândır

4 Bu târih manzûmeleri gazel, kıt‘a, beyit gibi nazım şekillerinden oluşmasına rağmen makalemizin metin kısmında söz konusu şiirleri muhtevâları gereği “Tarih Manzûmeleri” başlığı altında bir araya getirdik, âit oldukları nazım şekilleri kısmına ayrıca yazmadık.

5 Kemâleddin Harputî, Kasîde-i Münferice’nin Tahmîsiyle Berâber Türkçe Şerhidir, Ma ‘mûretü’l-azîz 1317, s. 4.

6 İbnülemîn, Son Asır Türk Şâirleri, II, 854. 
Ne yapsin hıdmetin îfâya tâb-âver değil Cibrîl

Anınçün müntehâ-yı hadd kadar icrâya pûyândır

Özün hâzır gözün nâzır tecelliyât-ı Rahmân’a

Sözün 'ilm-i ledün sırrını hâvî nass-1 Furkān'dır

Bu 'abd-i âsîyi mahrûm kılma yâ Habîballâh

Gece gündüz cemâlin iştiyâkı üzre giryândır

Benim tevbem dahi bir tevbeye muhtâcdır ammâ

Ümîdim sâye-i peygamberîde 'afv ü gufrândır

Kemâleddin Efendi aşka medhiye sadedinde "Kasîde-i Aşsk" başlı̆̆ ile bir şiir yazmış ve burada aşk-1 hakikīiyi tavsif etmiştir. İnsanın yaratılmasındaki hikmet aşk, eltâf-ı İlâhîye mazhar olmasının sırrı aşk, Hz. Âdem'e "ta 'lîm-i esmâ" eyleyen menba' aşk, Hz. Nûh'u sâhil-i selâmete çıkaran rehber aşk, Hz. Mûsầyı "Kelîmullâh" kılan nağme aşk, Hz. Îsâyı göklere çıkaran kanat aşk velhâsıl zât aşk, rûh aşk, akl aşk, kalp aşk, dîn aşk, îmân aşk, evvel, âhir, zâhir, bâtın aşktır!

'Aşkdır tağlardaki feryâd eden kalbî sadâ

'Âşıkın efgânı da bak sâhib-i efgân olur

Bil Kemâleddîn kim dînin kemâli aş̧kdır

'Aşkdan haz almayan üftâde-i nîrân olur

"Kasîde-i Sûfiyân" başlığını koyduğu şiirinde Kemâleddin Efendi sûfîce nasihatlerde bulunmaktadır. Hem nefsine hem okuyucuya Allah’tan başka her şeyden vazgeçmeyi öğütleyen Kemâleddin Efendi, Hak varken halka sığınmanın, halka derdini açmanın doğru bir tavır olmadığını, kişinin kendisini dünyevî meşgûliyetlerden kurtarıp kesrette vahdeti bulması gerektiğini anlatmaktadır:

Utan ey nefs-i gâfil Hakk’a dön şirk ü riyâdan geç

Dil-âgâh ol tecerrüd eyle meyl-i mâsivâdan geç

Yetişmez mi bu gafletle tekâpû ehl-i dünyâya

Yazık beyhûde ömrün geçmesin çûn ü çerâdan geç

Husûl-1 maksadın maksûd ise gel bâb-1 Mevlầya

Rezâletdir der-i mahlûk-1 dûna ilticâdan geç

Çalış kesretde vahdet bul Hudâya kalbi masrûf et

'Iyâl ü mâl ü evlâd ile sâde iktifâdan geç 
Yazdığg 11 beyitlik Arapça münâcâtta Kemâleddin Efendi’yi derdini, kederini yalnızca Rabbi'ne arz eden, O’ndan başkasına muhtâç olmak istemeyen, O’nun affına, merhamet ve keremine sı̆̆ınan samimi bir kul olarak görürüz:

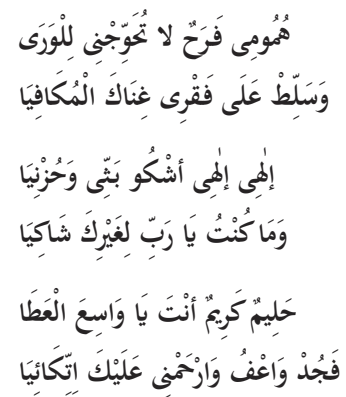

Kemâleddin Efendi Sultan Vahdeddin'in (VI. Mehmed, 1918-1922) cülûsundan Giritli Sırrı Paşa’nın (v. 1313/ 1895) vefâtına, medresede bazı kitapları okumaya başladığı yıldan icâzet aldığı yıla, çocuklarının doğumundan okul açılışına kadar çeşitli vesîlelerle târih düşürmüştür. Bunlardan Sultan Vahdeddin'in cülûsuyla ilgili manzûmesi ile Sırrı Paşa’nın vefâtı sebebiyle yazdığı gazel neşredilmiş, babası Abdülhamîd Hamdî ve ağabeyi Said Efendi’nin vefâtlarına düşürdüğü târihler mezar taşlarına hakkedilmiştir.

Kemâleddin Efendi’nin şiirlerinden her birinin şüphesiz bir hikâyesi vardır. Fakat muttali olduklarımız arasında en çarpıcısı bir yazma mecmuaya “Ârif Hikmet Bey'in gazeline zamânımızdaki ahvâle muvâfık bir sûretde yazdı̆̆ım bir nazîredir” serlevhasıyla kaydettiği “olalı” redifli gazelidir. Bu gazel Kemâleddin Efendi’nin istikbâlini karartan Şark İstiklâl Mahkemesi'ndeki yargılama, azil ve sürgün sürecinin en önemli bahânelerinden biridir. "Harput Ulemâsından Müderris-Müftü Mehmed Kemâleddin Efendi" başlıklı makalemizde teferruatlı bir şekilde ele aldığımız üzere, ${ }^{7}$ Ağustos 1926'da Şark İstiklâl Mahkemesi’nin emriyle Kemâleddin Efendi'nin evine yapılan baskında "Hükûmet-i milliyyenin meşrûiyyet ve teşekkülüne muhâlefeti ve makām-ı hilâfete sadâkat ve merbûtiyyeti mütezammın evrâk-1 muzırra", şapka takmak başta olmak üzere "teceddüd aleyhine" kaleme alınmış yazılar ve çocuklarına gönderdiği mektuplardan birinde yazılı olan "hilâfetin lağvı hasebiyle te'sîri hâvî bir manzûme" ele geçirilir. Kemâleddin Efendi'nin geriye kalan hayatını alt üst eden yukarıda saydığımız "suç malzemeleri” arasındaki "te’sîri hâvî manzûme” aşağıdaki gazeldir:

1. Kalem vekāi'-i devrâna tercümân olalı Sahâif üstüne âverde-i beyân olalı

2. Buna mümâsil olan hâdisâtı sanmam ki Geçirmiş ola sicille cihân cihân olalı

7 Ahmet Karataş, “Harput Ulemâsından Müderris-Müftü Mehmed Kemâleddin Efendi”, Marmara Üniversitesi İlâhiyat Fakültesi Dergisi, sy. 49 (İstanbul 2015), s. 56-63. 
3. Evet tebeddül ederdi hükûmet-i İslâm

Taraf taraf hulefâ sevreti 'ayân olalı

4. Fakat hilâfeti hem de şerîati ilgâ

Eden de var mı-dı hükkâm hükmrân olalı

5. Cinâyet 'addedilirmiş tilâvet-i Kur’ân

Bir ülkede bu olur muydu müselmân olalı

6. Sezâdır etse teessüf cihân Kemâleddîn

Şu hâli görmedi zîrâ zamân zamân olalı

7. Bunun da hikmetini 'ârif olmayan bilmez

Cihân cemâl ü celâl nûruna mekân olalı

Görüldüğg̈ gibi Kemâleddin Efendi hilâfetin ilgâsı başta olmak üzere, şerîatın ahkâmının yürürlükten kaldırılması, Kur’an tilâvetinin bile suç sayılır olmasından dolayı huzursuzdur. Ona göre târih bu türlü tavırlara şâhit olmamış, kalem yaratıldığı günden bu yana böyle uğursuzlukları yazmamış, "cihân cihân olalı" bu tarz hâdiselerle karşılaşmamıștır. $O$, hükûmetlerin değişmesine karşı değildir. İtirâz ve isyân ettiği husus hilâfetin ve bilhassa şerîatin ilgâsı, Kur’an tilâvetinin bile âdeta cinâyet addedilmesi ve memlekette bunlar olup biterken müslümanların büründügü sessizliktir."Bir ülkede bu olur muydu müselmân olalı" mısrâı bu isyânın nazma dökülmüş hâlidir.

Kemâleddin Efendi’nin yazdığı musammatlar arasında İbnülemîn'in iki gazelini taştîr etmesi (mutarref tahmîs) dikkat çekmektedir. Kıt'alarının bir kısmı ise Arapça ve Farsça rubâîlerin tercümelerinden oluşmaktadır.

Sonuç olarak, müderrisliği, müftülügü, ilmî eserleri ile akran ve emsâli arasında tanınan Kemâleddin Efendi, zaman zaman şiirler de kaleme almış bir âlimdir. Ancak bu şiirleri ile döneminin güçlü şâirleri arasına girmeyi başaramamıştır. O, klasik Türk edebiyâtının bilinen şekillerinin ve muhtevâsının dişına çıkmadan, XIX. asrın ikinci yarısı ile XX. asrın ilk çeyreğinde revâç bulan şiir tartışmalarından uzak kalarak ve şâirlik iddiasında bulunmadan şiirlerini yazmıştır.

Kemâleddin Efendi, şiirlerinde umûmiyetle nasihati ve irşâdı esas almış ve tasavvufî mâhiyeti öne çıarmıştır. Ancak bu şiirlerde kendine has mazmunlar ve bikr-i mânâ bulmak zordur. Ayrıca yer yer başta arûz hatâları olmak üzere bazı teknik kusurlara ve zorlamalara da rastlanmaktadır. Bu makalenin gâyesi onun çeşitli yazmaların varakları arasında ve devrinin gazetelerinde dağınık vaziyette bulunan manzûmelerini tespit edip şekil, tür ve kāfiye tertîbini gözetmek sûretiyle bir araya getirerek hâtırasını canlandırmak, onun edebî kişiliğine işâret etmek, bilhassa târih manzûmeleri yazdığı zevâtın hayatına ve devrinde olan bitene işık tutmaktır. 


\section{a) Kasîdeler ${ }^{8}$}

1

\section{[Münâcât] ${ }^{9}$}

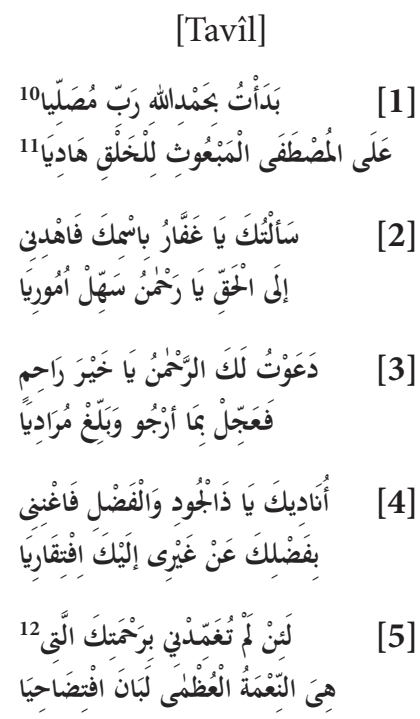

8 Kemâleddin Efendi’nin şiirlerini yazdığı sıradaki resmî-gayr-1 resmî mevkiini görmemiz için şiirlerinin sonuna koyduğu imzâyı yeri geldikçe dipnotlarda belirteceğiz.

9 Kemâleddin Efendi bu münâcâtı Şemseddin Muhammed b. Ahmed ed-Deyrûtî ed-Dimyâtînin (v. 921/1515) Kasîde-i Dimyâtiyye diye meşhur olmuş el-Kasîdetü'd-Dimyâtiyye fìt-tevessül bi-esmâillâhil-hüsnâ adlı kasîdesinden sonra okunması tavsiye edilen Zecr-i Dimyâtiyye adıyla şöhret bulmuş 20 beyitlik bir kasîdeye nazîre olarak yazmıştır. Zecr-i Dimyâtiyye

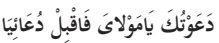

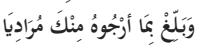

beytiyle başlamaktadır. Kasîde-i Dimyâtiyye Osmanlı topraklarında büyük bir şöhrete ulaşmış, Zecr-i Dimyâtiyye ile beraber bazı tarîkat ehli tarafından ne zaman, ne şekilde, hangi aralıklarla okunacağına dâir usuller belirlenerek vird hâline getirilmiştir. Kasîdenin yazma eser kütüphânelerinde bulunan birçok tercümesi, şerhi, tahmîsi araştırmacıların ilgisini beklemektedir.

Kemâleddin Efendi münâcâtını iki mecmûaya yazmıştır. Birinde şiir müstakil bir şekilde ve imzâlı olarak kayıtlıyken (AÜİF Kütüphânesi, Yazmalar Blm., nr. 38182, vr. nr. yok), diğerinde kendi manzûmesinin peşine Zecr-i Dimyâtiyye'yi boşluk bırakmadan ve imzâ koymadan ilâve etmiştir (Mütenevvi` Duâ ve Nüshalar Mecmûası, AÜİF Kütüphânesi, Yazmalar Blm., nr. 89, s. 144 [ Мecmua sayfalar esas alınarak numaralandırılmıştır]).

Zecr-i Dimyâtiyye için ayrıca bk. Mecmûa, Atatürk Kitaplığı, Belediye Yazmaları, nr. K. 1211, vr. $5^{\mathrm{b}}-6^{\mathrm{a}}$.

$10 \mathrm{Bu}$ misrâ eğer tevârüd değilse XVIII. asır Cezâyir ulemâsından Muhammed b. Übbe’l-Müzzemmirî elCezâirî et-Tevâtîye (v. 1160/1747) âittir. Müzzemmirînin 1116/1704'te yazdığı Dürerün-nühûr fî fekkil-buhûr adlı kasîdesi bu mısrâ ile başlamaktadır. (Müzzemmirînin hayatı, eserleri ve söz konusu kasîde hakkında bilgi için bk. Ahmed Ebü's-Sâfî Ca'ferî, Muhammed b. Übbe'l-Müzzemmirî hayâtuhu ve âsâruhu, Cezâyir 2004; Abdullah Ammârî, Muhammed b. Übbe'l-Müzzemmirî el-Cezâirî et-Tevâtî ve cühûduhû fìn-nahvi, yüksek lisans tezi, 2010, Cezâyir Kasdi Merbah-Ouargla Üniversitesi, Dil ve Edebiyat Fak. Arap Dili ve Edebiyatı Blm; http://www.taouat. net/main/index.php/2014-10-23-10-10-09/45-2011-01-23-10-14-52/321-1160. [Erişim târihi: 27.02.2016])

$11 \mathrm{Bu}$ misrâ da kezâ tevârüd değilse Ömer b. Bâb (v. 1145/ 1732) isimli bir âlim ve edîbin Kasîdetü Tevessüliyye bi-esmâillâhi'l-hüsnâ isimli şiirinin son mısrâıdır. Kasîde Moritanya Ehlü’t-Tâlib Bi-bekr Kütüphânesi’nde 0430/5415 nr. ile kayıtlıdır. Kasîdenin son beytinin ilk mısrâı ile Kemâleddin Efendi’nin manzûmesinin ilk mısrâı da aslında birbirine çok yakındır:

“" "كملت بحمد الله نظمي مصليا" bk. http://makrim.org/manuscrits.cfm?PN=282. (Erişim târihi: 27.02.2016)

1289 numaralı nüshada bu misrâdaki "’ "’ yok. 


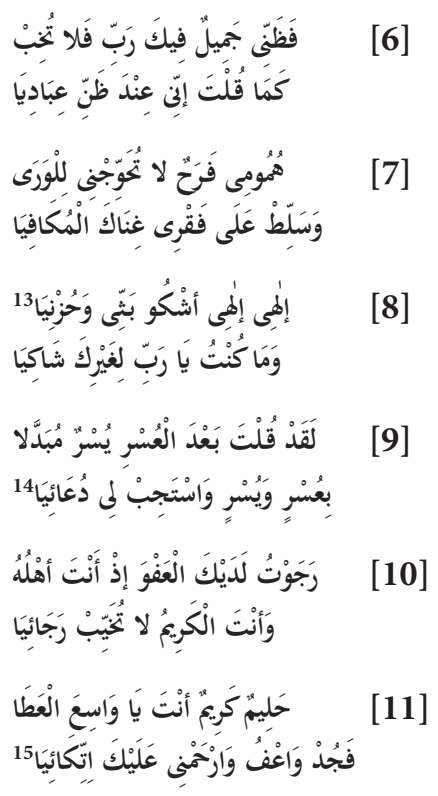

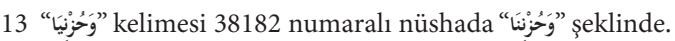

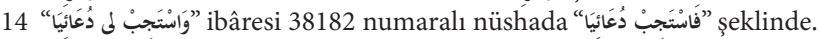

15 Kémâl. Mecmûa, AÜİF Kütüphânesi, Yazmalár Blm., nr. 38182, vr. nr. yok; Mütenevvi“ Duâ ve Nüshalar Mecmûası, AÜİF Kütüphânesi, Yazmalar Blm., nr. 89, s. 144.

Münâcâtın tercümesi:

1. Rabbim Allah'a hamd ederek ve yaratılanlara yol gösterici olarak gönderilen Mustafầya (s.a.v.) salavât getirerek başladım.

2. Ey Gaffâr olan Allahım! Niyâzım odur ki ismin hürmetine beni hak yola iletesin ve ey Rahmân, işlerimi kolaylaştırasın.

3. Ey merhamet edenlerin en hayırlısı olan Rahmân! Sana duâ ettim. İsteklerime beni bir an evvel kavuştur, umduğuma nâil eyle!

4. Seslenişim sanadır ey kerem ve fazîlet sâhibi! Beni lutfunla başkalarından müstağnî eyle, ben sana muhtâcım!

5. Beni en büyük nimetin olan rahmetinle bağışlayıp günâhımı örtmez isen ayıp ve kusurlarım ortaya çıkar, rezil rüsvâ olurum.

6. Seni güzel bilirim yâ Rabbi! Beni hayâl kırıklığına uğratma. "Ben kulumun beni bildiği gibiyim.” demiştin ya...

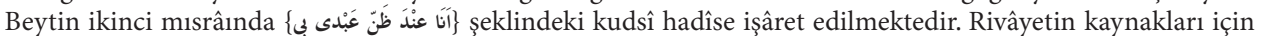
bk. Buhârî, el-Câmiu's-sahî̀h (thḱ. Taḱlyyüddîn en-Nedvî), Beyrut 2011, XIV, 438 (hadis nr. 7405); Müslim, elCâmi'u's-sahîh, Riyâd 2006, II, 1234 (hadis nr. 2675); Ahmed b. Hanbel, el-Müsned (thk. Ahmed Muhammed Şâkir- Hamza Ahmed ez-Zeyn), Kahire 1995, XI, 111 (hadis nr. 13125), 311 (hadis nr. 13874), a.g.e., XIII, 221 (hadis nr. 16916); Tirmizî, el-Câmi'u's-sahîh (thk. Abdullah b. Abdulkādir et-Tancî), Beyrut 2015, III, 530 (hadis nr. 3370); İbn Mâce, es-Sünen, Riyâd 1986, II, 322 (hadis nr. 3822/3080).

7. Üzüntülerim ferahlıktır. Beni halka muhtaç eyleme. Yoksulluğumu sonsuz kereminle yok et.

8. Yâ Rabbi! Yâ Rabbi! Ben hüznümü ve kederimi sana arz ediyorum. Senden başka kimseye el açıp hâlimi şikâyet etmedim.

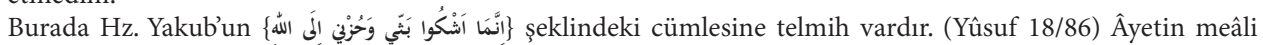
şöyledir: "Ben hüznümü ve kederimi yalnız Allah'a arz ederim."

9. “Zorluktan sonra kolaylık vardır." dediydin. Zorlukta da kolaylıkta da duâlarımı kabul buyur.

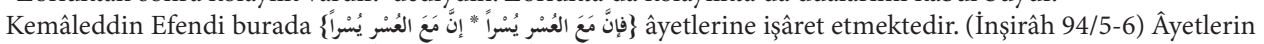
meâli şöyledir: "Muhakkak ki hér zorlukla béraber bir kolaylık vardır. Evet, her zorlukla beraber bir kolaylık vardır."

10. Dergâhında af dilerim. Çünkü affetmek senin şânındandır. Sen cömertsin Allahım, dileklerim husûsunda beni yaniltma.

11. Halîmsin sen, kerîmsin ey ihsânı bol Rabbim! İhsân buyur, affet, bağışla beni... Dayanağım sensin. 


\section{Bir Na't-i Șerîf-i 'Ârifâne}

[Mefầîlün mefâ‘îlün mefâ‘îllün mefâ‘îlün]

1. Resûl-i Kibriyâ'nın hulk-1 pâki 'ayn-1 Kur'ân'dır

Hadîs-i Hazret-i Sıddîk’a bu matlûbe burhândır ${ }^{16}$

2. Sen ol mahlûk-1 evvel nûr-1 ekmel 'aynü'l-a'yânsın

Cemâlin pertevi eflâk-i "levlâk"e fürûzândır ${ }^{17}$

3. Muhabbet ism ü cismin zînet etmiş bezm-i hestîye

Vücûdun pâş edilmiş fark-1 halka nûr-1 imkândır

4. Evet mir'ât-ı zâtındır bize i'lân eden Hakk'1

Hakỉkatde vücûdun zîb-bahş-1 sırr-1 ekvândır

5. Nübüvvet rütbesinde vâyedâr-1 sebk olan sensin Safiyy-i Ekrem'e mesbûkun olmak pek büyük şândır

6. Nebiyy-i muhterem bir sırr-1 mübhemdir hakikatde Egerçi sûretâ meşhûd olur ki 'aynü’l-insândır

7. Enîsi Hak celîs-i bezm-i ünsâ-üns-i lâhûtî Ricâl-i sıdk u 'adl ü şerm-i tâm ü genc-i 'irfândır ${ }^{18}$

8. Ulü'l'azm enbiyâyı iktidâya eyledin mecbûr İmâmü'l-enbiyâ temyîz-i zâtınçün bir 'unvândır

9. Burâk u berkı geçdin âlem-i lâhûtı seyr etdin Ve “mâ zâğe'l-basar"dan kasd-1 Kur’ân kadrin i'lândır ${ }^{19}$

10. Ne yapsın hıdmetin îfâya tâb-âver değil Cibrîl ${ }^{20}$ Anınçün müntehâ-yı hadd kadar icrâya pûyândır

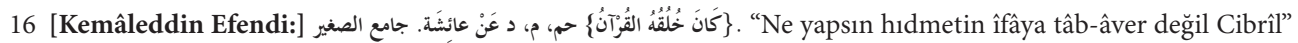
حم: Ahmed b. Hanbel; p: Müslim; د: Ebû Dâvûd.

Hz. Âişe’ye âit olan yukarıda parantez içindeki söz “Onun [Hz. Peygamber] ahlâkı Kur'an'dı.” mânâsına gelmektedir. bk. Süyûtî, el-Câmi'u's-sağîr, AÜİF Kütüphânesi, Yazmalar Blm., nr. 36447, vr. nr. yok. (Bu nüsha Kemâleddin Efendi’nin husûsi kütüphânesinde bulunan, ilk varağında kıraat kaydının ve imzasının bulunduğu nüshadır.); Taberânî, el-Mu'cemü'l-evsat (thk. Târık b. Avdullâh b. Muhammed-Abdü'l-muhsin b. İbrâhîm el-Hüseynî), Kahire 1995, I, 30 (hadis nr. 72); İbn Hacer el-Askalânî, İthâfü'l-mehere (thk. Yûsuf Abdurrahmân el-Mar'aşlî), Medîne 1999, XVI, 1065 (hadis nr. 21630).

17 "Levlâk" lafzı hadîs-i kudsî olduğu söylenen ve “(Ey Muhammed!) Sen olmasaydın, sen olmasaydın âlemleri

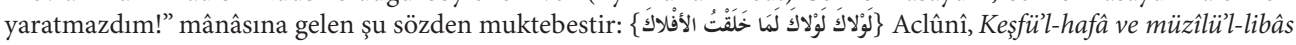
ammâ iştehera mine'l-ehâdîs 'alâ elsinetinn-nâs, Beyrut 1351, II, 164 (hadis nr. 2123).

18 Sidk ile Hz. Ebûbekir, 'adl ile Hz. Ömer, şerm-i tâm ile Hz. Osman, genc-i 'irfân ile de Hz. Ali kastedilmiştir.

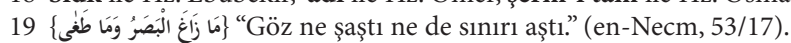

20 Cerîde-i Sûfiyye’de bu misrâ burada değildir. Kemâleddin Efendi’nin hadîs-i şerîfi kaydettiği yukarıdaki dipnotun sonuna dizgi aşamasında sehven yazıldığını düşündüğümüz mısrâı okuduğumuzda onun yerinin burası olduğunu düşündük ve mısrâı yerine yerleştirdik. 
11. Özün hâzır gözün nâzır tecelliyât-1 Rahmân’a

Sözün 'ilm-i ledün sırrını hâvî nass-1 Furkān'dır

12. O "vaktün" kim mukarrebler bile mahrûmdur andan ${ }^{21}$

Cenâb-1 kuds-i a lâdan sana bir lutf-1 Sübhân’dır

13. Meleklerdir zahîrin nâsırın Cibrîl ile Mevlâ

Mutî́-i emr-i pâkin sâlihân-1 ehl-i îmândır ${ }^{22}$

14. Şu hâlde ketm-i esrâr eylemek mümkün müdür senden

Anınçün ümmehât-1 mü’minîn münkād-1 fermândır

15. Kamer sadr-1 şerîfin nisbetin ihrâz kılınmışdır

Anı taklîd ile şakk olmağa elbette çespândır

16. Halâik büsbütün münkād-1 emrin yâ Resûlallâh

Kemîne kullarından biri Mâlik biri Rıdvân’dır

17. Eyâ Fahru’r-rusül hâdi’s-sübül mahbûb-1 Rabbü'l-küll

Visâl ü firkatin anlar birer dârına derbândır

18. Bu 'abd-i âsîyi mahrûm kılma yâ Habîballâh

Gece gündüz cemâlin iştiyâkı üzre giryândır

19. Habîb-i Ekrem'in 'aşkıyla tenvîr etmeyen kalbi

Yine hayvândır ammâ şekl-i insânda nümâyândır

20. Kapandı pîş-i 'azmim gaflet ile râh-1 'irfânda

'Alâik 'âik oldu kâr ü bârım sâde hüsrândır

21. Şühûd-1 merd-i gâfil semm-i kātildir hakỉkatde

Veren nûr-1 hayâtı sohbet-i erbâb-1 irfândır

22. Günehkârım zelîlim rû-siyâhım yâ Nebiyyallâh!

Kapunda bir kemîne bendeyim ümmîdim ihsândır

23. Masûn et çâr-yârin hürmetine çâr düşmenden

Hasûd u nefs-i emmârem ile küffâr ü şeytândır

24. Resûl-i müctebâdan başka yokdur ilticâgâhım

Şefî̀-i rûz-1 mahşer çâresâz-1 derd-mendândır

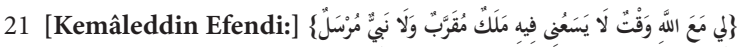

"Benim Allah'la öyle bir vaktím vardır ki, né mukarreb bir melek ne de mürsel bir peygamber benimle birlikte o vakte sığar." Aclûnî, Keşfü̉l-hafâ, II, 173 (hadis nr. 2159).

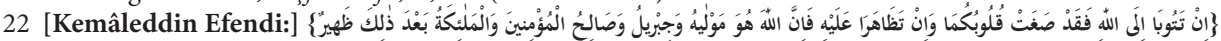

“(Ey Peygamber'in eşleri!) İkiniz de Allah’a tevbe ederseniz, kaymı́s olan kalpleriniz düzelmiş olur. Peygamberin aleyhine yardımlaşarak bir şey yapmağa kalkarsanız bilesiniz ki onun dostu ve yardımcısı Allah, Cebrâil ve mü’minlerin iyileridir. Ayrıca melekler de ona arka çıar." (et-Tahrîm 66/4) 
25. Benim tevbem dahi bir tevbeye muhtâcdır ammâ Ümîdim sâye-i peygamberîde 'afv ü gufrândır

26. Değildir mümteni' 'afvım ümîdim münkatı' olmaz Husûsan müşkil işler lutf-1 Hak’la cümle âsândır

27. Ne mümkin hâme-i mahlûk-1 âciz eylemek tavsîf Cenâb-ı Mustafầnın vâsıfı mâdem ki Yezdân'dır

28. Amân ey bâ'is-i hilkat-penâh-1 a'zam-1 ümmet Kemâleddîn kulun 'afv et esîr-i kayd-1 'isyândır ${ }^{23}$

3

\section{$[\text { Medhiye }]^{24}$}

[Fe'ilâtün fe'ilâtün fe'ilâtün fe'ilün]

\section{Bize Hakk’ın ulu bir ni'meti Es'ad Paşa Çünki ihyâ ediyor milleti Es'ad Paşa}

\section{Açıyor gözleri Îsî nefesi câiz olup Aldı hakkı ile bu şöhreti Es'ad Paşa}

23 Kemâleddin Harputî. Cerîde-i Sûfiyye nr. 24/12 (9 Muharrem 1331/ 19 Aralık 1912), s. 10.

24 Kemâleddin Efendi bu gazeli İstanbul'da kendisini tedâvi eden dönemin meşhur göz tabiblerinden Mehmed Esad Paşa ([Işık], v. 1355/1936) için yazmıştır. Mehmed Esad Paşa Anadolu’nun ilk modern göz kliniğini kuran mühim bir doktor olmasının yanında Millî Mücâde yıllarında Millî Kongre’nin kurucuları arasında yer alan ve bu sebeple önce İstanbul Hükûmeti tarafından Kütahya’ya, İstanbul'un işgali sonrasında ise 1920'de İngilizler tarafından Malta'ya sürülen münevverlerden biridir. Esad Paşa sürgünden sonra bir müddet Ankara'da sonra İstanbul'da asıl mesleğini devam ettirdi. 1931'de Dârülfünûn Tibbiyye'de serîriyyât-1 ayniyye (göz hastalıkları) müderrisi olarak vazifeye bașladı, ancak 1933’teki Üniversite Reformu neticesinde kadro dıșı bırakıldı. Esad Pașa edebiyata merakı olan ve ara sıra şiirler yazan bir zâttı. Bazı beyitleri hattatlar tarafından yazılıp duvarları süsleyecek kadar sevilmiştir. Nâmık Kemâl'den duyduğu "Akla karayı seçecek kadar izânı olan adam bu memlekette yaşamaz!" sözüne atfen söylediği

Bir şahıs olsa da medîdü'l-basar Bir de gözlük takarak etse nazar

Kalkmayınca zulmet-i cehl aradan Edemez tefrîk akı karadan

misrâları,

Acırım ben o zaîf gözlülerin hâllerine Hurde eşyâyı görür nûr-ı hakīkatı görmez

ve Kemâleddin Efendi’nin hayatını anlattığımız makalede de kaydettiğimiz

İhtiyârımla aceb ben hiç olur muydum tabîb Ger bileydim âlemin bunca devâsız derdini

gibi beyitleri onun hikmetli söyleyişlerine örnek verebiliriz. Süheyl Ünver Bey'in, hocası Esad Paşa'ya "Işık" soyadını alma sebebini sorması üzerine "Küfre giden yol sönsün, İslâmiyet parlasın, İslâmiyet'i mahveden cehl kalksın diye...” şeklinde verdiği cevap hamiyyet-i dîniyyesini göstermesi bakımından câlib-i dikkattir.

Esad Paşa ile ilgili daha teferruatlı bilgiler için şu çalışmalara bakılabilir: Necmeddin Rıfat Yarar-A. Süheyl Ünver, Müderris Doktor ve Göz Mütehassısı Esad "Işık” Paşa, İstanbul 1972; H. Kadircan Keskinbora, Bilimde, Siyasette, Milli Mücadelede Bir Işık: Esat Işık, İstanbul 2010; a.mlf., Mehmet Esat Ișık Paşa: Hayatı Tıp Tarihimizdeki ve Türk Oftalmoloji Tarihindeki Yeri ve Katkıları, (doktora tezi, 2006), İstanbul Üniversitesi Sağlık Bilimleri Enstitüsü; Hasan Basri Sayı, Osmanlı Belgeleri Ișı̆̆ında Dr. Esat Bey’in Biyografisi ve Görme Engellilere Yönelik Eğitim Çalışmaları, yüksek lisans tezi, 2008, Selçuk Üniversitesi Sosyal Bilimler Enstitüsü; Şeref Etker, “Ophtalmoscope Essad”, Osmanl Bilimi Araştırmaları, IX/1-2 (İstanbul 2007-2008), s. 151-164. 
3. Âlemin mürşididir dense sezâdır el-hak Bize ibrâz ediyor kudreti Es'ad Paşa

4. Hazretin kadrini takdîr edemez kör millet Bilir elbet dahi bu hikmeti Ešad Paşa

5. Tâ ebed şükr-güzârı kalacak Müftî Kemâl Çünki yükletdi ana minneti Es'ad Paşa $(\text { Muharrem } 1336 \text { [Ekim 1917]) })^{25}$

Kasîde-i 'Aşsk

[Fấilâtün fấilâtün fấilâtün fấilün]

1. Hâke pertev-bahş olunca 'aşk-1 Hak insân olur Masdar-1 esrâr-1 Mevlâ mazhar-1 'irfân olur

2. Âdeme ta'lîm-i esmâ eyleyen hem 'aşk idi 'Aşkdan mahrûm olan bî-şübhe kim nâdân olur

3. Nûh-ı nâcî garkden rehyâb olupdur 'aşk ile Keștî-i 'aşka giren âzâde-i tûfân olur

4. 'Aşk idi Tûr üzre Mûsầyı Kelîmullâh eden Şehper-i 'aşk ile 'Îsâ göklere pûyân olur

5. Enfüs ü âfâka 'aks itdükde nûr-1 şems-i 'aşk ${ }^{26}$ Kûh u murgân Hazret-i Dâvûd'a hem-elhân olur

6. Nüsha-i 'aşka denür Tevrât ü İncîl ü Zebûr Ümmet-i merhûmeye nisbetle de Kur'ân olur

7. 'Aşkdır tağlardaki feryâd eden kalbî sadâ '̂ş̧ıkın efgânı da bak sâhib-i efgân olur çıkmıştır. 
8. Mihr-i 'aşkın bedri 'âşık eylemişdir zâtına

Mihr ü meh kevkeb bütün 'aşkın ile tâbân olur

9. Zât 'aşkdır rûh 'aşk u 'akl 'aşk u kalb 'aşk

'Aşk İslâm 'aşk hem dîn 'aşk hem îmân olur

10. Bil Kemâleddîn kim dînin kemâli ‘aşkdır

'Aşkdan haz almayan üftâde-i nîrân olur ${ }^{27}$

5

\section{Kasîde-i Sûfiyân}

[Mefầîlün mefâ‘îllün mefâ‘̂ilün mefầîlün]

1. Utan ey nefs-i gâfil Hakk'a dön şirk ü riyâdan geç ${ }^{28}$

Dil-âgâh ol tecerrüd eyle meyl-i mâsivâdan geç

2. Yetişmez mi bu gafletle tekâpû ehl-i dünyâya

Yazık beyhûde ömrün geçmesin çûn ü çerâdan geç

3. 'Alâikdir 'avâik ehl-i isti'dâd iken insân

Bırak esbâbı mâni‘ bulduğun fakr u gınâdan geç

4. Nihâyet mi olur bu tûl-1 âmâle cihândır bu

Bekā bulmak dilersen fânî ol evvel bekādan geç

5. Ru'ûnetden kaçıp dikkatle tehzîb-i sıfât eyle

'Isâmî ol '1zâma intisâb ü intimâdan geç²9

27 Harputlu Kemâleddin. Beyânül-Hak, nr. V/105 (9 Rebîulâhir 1329/ 9 Nisan 1911), s. 1952; Cerîde-i Sûfiyye nr. 24/18 (4 Rebîülâhir 1331/ 13 Mart 1913), s. 7. İbnülemîn kitabına bu kasîdenin yedi, İshak Sunguroğlu da üç beytini almıştır (bk. İbnülemîn, Son Asır Türk Şairleri, II, 855; İshak Sunguroğlu, Harput Yollarında, İstanbul 1959, II, 175).

28 İbnülemîn ve Sunguroğlu neşirlerinde bulunan "şirk ü riyâdan” ibâresi Beyânül-Hak'da "terk-i riyâdan" șeklinde.

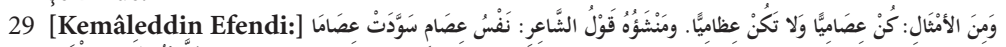

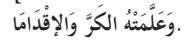

"Atasözlerinden biridir: Kendinle iftihar et edeceksen, göçüp gitmiş babalarınla övünme! Bu sözün kaynağ da şâirin şu sözüdür: 'Isâm’ın kendisinden kaynaklanan fazîlet ve meziyetleri onu meşhûr eyledi. Bu meziyetler ona her mücâdelede ve her konuda öne çıkma cesâreti kazandırdı." (Atasözü şevâhid olarak yazılan beyitle beraber Lisânü'l-Arab'da yer almaktadır. İbn Manzûr, Lisânüll-Arab, “عصم” maddesi, Beyrut 1999, IX, 248.)

Kemâleddin Efendi’nin iktibâs ettiği beyit Câhiliye dönemi Muallaka-i Aşere şâirlerinden Nâbiğatü’z-Zübyânî (v. 604 [?])'ye atfedilen bir kıt'anın ilk iki mısrâıdır. Kıt'anın tamamı şu şekildedir:

تَفْسُ عِصَام سَوَّدَتُ عِصَامَا

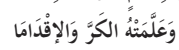

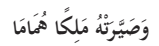

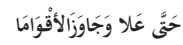




\title{
6. Husûl-1 maksadın maksûd ise gel bâb-1 Mevlâya Rezâletdir der-i mahlûk-1 dûna ilticâdan geç
}

\section{7. Çalış kesretde vahdet bul Hudâya kalbi masrûf et 'Iyâl ü mâl ü evlâd ile sâde iktifâdan geç}

\section{Tekâmül eylemek bî-şübhe varlıkla münâkızdır Yok ol yoklukla var maksûda 'ilm ü iddiâdan geç}

\section{Karâr ister isen evvelce tashîh-i karâr eyle ${ }^{30}$ Mürîd oldunsa ta'kỉb-i murâda i'tinâdan geç}

\section{Vücûdun bir günehdir 'aşk içinde mahv ü nâ-bûd et Hümûmun hemm-i vâhid eyle halka iştikâdan geç}

\section{Seni senden alır isterse Mevlâ bezl-i makdûr et Deme mümkin değil bu olmaz olmaz iftirâdan geç}

\author{
12. Ma'iyyetle muhabbetden iki şehper küşâd eyle \\ Harîmü'l-ünse uç mahbûs kalma bu hevâdan geç
}

\footnotetext{
"Isâm’nn kendisinden kaynaklanan fazîlet ve meziyetleri onu meşhûr eyledi. Bu meziyetler ona her mücâdelede ve her konuda öne çıkma cesâreti kazandırdı. Isâm bu vasıflarıyla yüceldikçe yüceldi ve her topluluğun karşısında âdeta kıymetli bir kral hâline geldi."

(bk. Dîvânu’n-Nâbiğatüz-Zübyânî, Mısır 1911, s. 114; Dîvânu’n-Nâbiğatüz-Zübyânî [thk. Muhammed Ebü’l-fazl İbrâhîm], Kahire 1985, s. 232.)

Ulaştı̆̆ımız kaynaklarda yer alan rivâyetlere göre, Hîre (Irâk) meliki Nưmân b. Münzir’in (580-602) Isâm b. Şehr veya Isâm b. Şehber adında bir veziri varmış. Bu zât fesâhat ve belâğatte büyük şöhrete ulaşmış, Câhiliyye döneminde herkesin kendisine saygı gösterdiği biri hâline gelmiş. Ancak o, övülen meziyetleri ve büyük şöhretine rağmen mütevâzı ve kendine hâkim kişiliği ile "Hâricî” yani “nefsini aradan çıkaran" biri olarak anılıyormuş. Devrin en kuvvetli şâirlerinden Nâbiğatü'z-Zübyânî yakînen tanıdığı Isâm için bu şöhretin şımartmadığı karakterine binâen yukarıdaki kıt'ayı yazmıştır.

Yine rivâyete göre Emevî vâlilerinden Haccâc'a (ö. 95/714) cehâletiyle tanınan bir adamı vasfederler. Adamın bir gün Haccâc’a işi düşer. Haccâc işini görmeden önce câhilliğini ölçmek amacıyla onu sınamaya karar verir. Huzûra alındığında adama "Sen Isâmî misin yoksa ızâmî misin?" diye sorar. Yani müktesebâtıyla mı yoksa göçüp gitmiş geçmişleriyle mi iftihâr ettiğini öğrenmek ister. Adam kısa bir şaşkınlıktan sonra "Ben Isâmî ve izâmîyim!" der. Bunun üzerine Haccâc "Bu adam insanların en hayırlılarındandır." diyerek adamın ihtiyaçlarının giderilmesini emreder, ona ihsanlarda bulunur ve bir müddet yanında kalmasına izin verir. Fakat biraz araştırınca adamın hakikaten çok câhil biri olduğunu görür. Adamı yanına çağırır ve ona kızgın bir sesle "Doğruyu söyle! Yoksa seni öldürürüm!" der. Adam hayretler içerisinde "Ne oldu ki? Neyi doğru söyleyeyim?" der. Haccâc "Sana sorduğum o soruya o cevâbı nasıl verdin?!" Adam "Vallahi Isâmî mi desem doğru olurdu, izâmî mi bilemedim. İkisinin de ne mânâya geldiğinden haberim yok. Bu sebeple yalnızca birini söyleyip hatâ yapmaktan korktum da ikisini söyleyiverdim! Birisi aleyhime olursa diğeri lehime olur diye düşündüm." Meğer Haccâc adamın "Fazîletimden dolayı kendimle, şereflerinden dolayı da ecdâdımla iftihâr ederim.” demek istediğini zannetmiş. Adamın cehâleti karşısında Haccâc

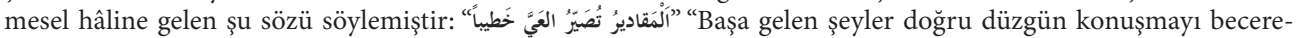
meyen kişiyi bile kuvvetli bir hatîp hâline getirebiliyor!”

(bk. el-Meydânî en-Nîsâbûrî, Ebü'l-fazl Ahmed b. Muhammed, Mecma'u'l-emsâl [thk. Muhammed Muhyiddin Abdülhamîd], Beyrut 1972, II, 331, nr. 4189, "Nefsu Isâmin sevvedet Isâmen"); Ebû Yakub Yusuf b. Tahir Huveyyî, Ferâidü'l-harâid fill-emsâl [thk. Abdurrezzâk Huseyn], Ürdün ty., s. 537.)
}

30 tashîh-i karâr: tashîh-i firâr (Beyânüll-Hak) 
13. 'Asâya vermesin gönlün rızâ şehrâh-1 'irfânda Münâfî-i edebdir mâsivâya ittikâdan geç

14. Gelip dergâh-1 pîre iktihâl et hâk-i pâyinden Basîret dîdesin mekşûf kıl artık 'amâdan geç

15. Egerçi ehl-i 'isyândır Kemâleddîn kulun yâ Rab Bırakma nâr-1 hicre etdigi cürm ü hatâdan geç

16. Bağışla Ahmed-i Muhtâr'e o 'abd-i günehkârı Yolunda yapdığı küstâhlık ile ictirâdan geç

14 Şa'bân [1]328 [21 Ağustos 1910] $]^{31}$

\section{b) Târih Manzûmeleri:}

\section{6}

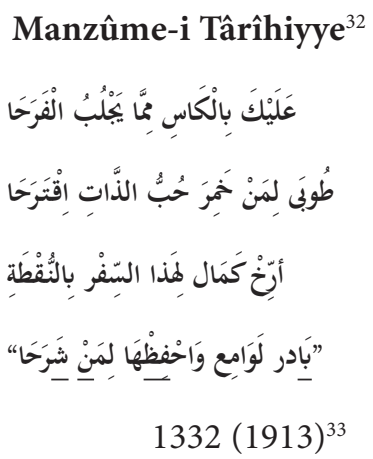

31 Kemâleddin Harputî. Beyânül-Hak, IV/79 (22 Ramazan 1328/ 27 Eylül 1910), s. 1525. Bu şiirin yedi beyti İbnülemîn'in Son Asır Türk Şairleri’nde (II, 855) ve İshak Sunguroğlu’nun Harput Yollarinda (II, 174) Kemâleddin Efendi'nin manzûmelerine örnek olarak kaydedilmiştir.

32 Kemâleddin Efendi bu mu'cem târih kıt'asını Abdurrahmân Câmînin (v. 898/1492) İbn Fârız’a (v. 632/1235) ait 41 beyitlik Arapça Kasîde-i Hamriyye (Mîmiyye)'sinin manzum-mensur şerhi olan Farsça Levâmi ini tercüme etmeye başlarken yazmıștır. Tercüme tefrikalar hâlinde 1331'in sonu ile (1913) 1336 (1917) arasında Cerîde-i Sûfiyye'de neşredilmiştir. Kıt'a son tefrikada yayımlanmıştır (bk. Cerîde-i Sûfiyye, nr. 132 [27 Safer 1336], s. 330). Tefrikanın neşredildiği sayılar için bk. Ahmet Karataş, "Harput Ulemâsından Müderris-Müftü Mehmed Kemâleddin Efendi”, s. 86-88.

33 Ma'mûretü'l-azîz Vilâyeti Müftîsi Kemâleddin.

Kıt'a şu mânâya gelmektedir: "Ferahlık veren şeylerden olan kadehi al eline. Ne mutlu güzel bir tercihle zâtın sevgisini yudumlayana! Kemâl! Bu kitap için nokta ile (noktalı harflerle) târih düşür! Hemen Levâmi ${ }^{\circ}$ e (Levâmi ${ }^{\circ}$ in tercümesini yazmaya) koyul ve onu şerh edecekler için muhâfaza et/ ezberle!” İkinci mısrâdaki “"اقتَرَّ" kelimesi

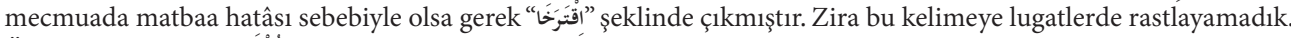

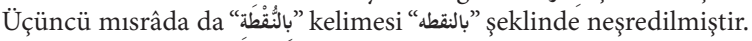




\title{
İlk eşi Mutîa Hanım’ın vefâtına düşürdüğü târih:
}

\author{
[Mefấilün fe ilâtün mefầ'ilün fe'ilün (fa'lün)]
}

Mutî́a Hânım’ mağfûr ede Cenâb-ı Hudâ

Bu sâl içinde vedâ‘ etdi âleme hayfâ

Kemâl hâtır-1 mahzûna geldi bir târîh

Mutî́a Hânımia her dem na î̀m ola me’vâ

مطيعة خانمه هر دم نعيم اوله مأوى

$1349(1930)^{34}$

\section{8}

\section{Ahmed İzzet Paşa'nın vefâtına düşürdügü târih:}

[Fâ'ilâtün fe'ilâtün fe'ilâtün fe 'ilün]

\author{
Hayf vâlî-i Edirne Teres İzzet Paşa \\ Etdi oğlan diyerek hasret ile terk-i hayât \\ On püser çıkdı dedi dâireden nevha-künân \\ İki lafz-1 teres oldu ona târîh-i vefât
}

1320-10=1310 = "ترس ... ترس"

34 Mecmûa, AÜİF Kütüphânesi, Yazmalar Blm., nr. 36143, vr. nr. yok. Mutîa Hanım’la ilgili bilgi için bk. Ahmet Karataş, "Harput Ulemâsından Müderris-Müftü Mehmed Kemâleddin Efendi”, s. 102-103.

35 Kemâleddin Efendi’nin imzâlarının olduğu varakta kayıtlı olan bu kıt’ayı başka kaynaklarda rastlayamadığımız için buraya yazdık. Kıt'anın sonuna "li-nâzımihî, nâzımuhû, li-muharririhî" gibi bir kayıt düşmediğinden kıt'anın ona âidiyetine ihtiyâtla yaklaşıyoruz. Mecmûa, AÜİF Kütüphânesi, Yazmalar Blm., nr. 38182, vr. nr. yok.

Hacı Ahmed İzzet Paşa XIX. asrın başlarında doğmuştur. Bazı memuriyetlerinin ardından muhtelif târihlerde Hakkâri, Şâm, Cidde-Hicâz, Girit, Diyârbekir, Harput (Ma'mûretü'l-azîz), Trablus-1 Garb, Sivas, Erzurum ve son olarak Edirne vâliliklerinde bulunmuş, 1310/1893'te burada vefât etmiş bir devlet adamıdır. Kaynaklar iyi bir hattât, şâir, edîb olan İzzet Paşa’nın nev’i şahsına münhasır bir zât olduğunu yazmaktadır. "Pezevenk” anlamına gelen “teres” kelimesini “İnandı teres!” yahut “Anladı teres!” gibi cümleler içinde çok sık kullandığı için adı “Teres İzzet Paşa” ya çıkmıştır. Gerek "teres” etrâfında söyledikleri, gerekse nükteleri ve garip ahvâli fikralara konu olmuştur. İzzet Paşa Harput vâlisi iken (1863-1867) Sultân Abdülazîz'in tahta çıkışının beşinci yılı (1866) şerefine, Harput’un eteklerindeki ovada yayılmış olan ve hükûmet konağı, câmi, mekteb gibi yapıların da inşâ edildiği ve o güne kadar Ağavât Mezra'ı / Mezra‘ olarak anılan meskûn mahallin adının Ma‘mûretü’l-azîz olarak değiştirilmesi yönünde tezkere hazırlayarak Sadârete göndermiştir. Teklifin kabul edilmesi üzerine yüzlerce yıllık Harput vilâyetinin adı Ma'mûretü'l-azîz olmuştur. Ovadaki yerleşimin yanısıra resmî dâirelerin de oraya taşınması sebebiyle her geçen gün nüfûsunu kaybeden Harput 1899'da kazâya, 1926'da da nâhiyeye dönüşmüş, bugün ise tepelerine yayılmış mezarlıkları ve seyrek evleri ile Elazı̆̆’a bağlı bir mahalle hâline gelmiştir.

Ahmed İzzet Paşa’nın inşâ ve ihyâ ettiği birçok eser arasında bilhassa Elaziz’de bir zamanlar Bağdat Caddesi olarak 


\title{
Aldığı icâzet-i ilmiyye vesîlesiyle düşürdüğü târih:
}

[Mef'ûlü mefầîlü mefầ îlü fe ûlün]

\author{
Târîh çıkar bir iyi îhâmı da vardır \\ Tevfîk ile aldım bu sene ben de icâzet
}

توفيق ايله الدم بو سنه بن ده اجازت

$(1313-1=1312)^{36}$

$\underline{10}$

\author{
Sırrı Paşa Merhûmun Vefâtına Târîhdir ${ }^{37}$ \\ [Fấilâtün fe'ilâtün fe'ilâtün fe'ilün (fa'lün)] \\ 1. İftihâr-1 vüzerâ Hazret-i Sırrı Paşa \\ Genç iken eyledi bu sâlde eyvâh vefât
}

bilinen şimdiki Gâzi Caddesinde kendi adına, Erzincan'da da kendisinden 40 yıl önce vefât eden çok sevdiği ve unutamadığı oğlu Hurrem Paşa adına yaptırdığg câmiler meşhurdur. El'azîz'in ilk matbaasının da (Ma'mûretü'lazîz Vilâyet Matbaası) İzzet Paşảnın vâliliği esnasında kurulduğunu, bu matbaada ilk basılan eserin ise Kemâleddin Efendi’nin dedesi Ömer Naîmî Efendi’nin Manzûme-i Na îmiyye'si (1866) olduğunu ayrıca belirtmemiz gerekir. (Daha teferruatlı bilgi için bk. Mehmed Süreyyâ, Sicill-i Osmânî, İstanbul 1311, III, 465; Fatin Dâvûd, Hâtimetü'leşầr [haz. Ömer Çiftçi], Ankara ty., s. 304; İbnülemîn, Son Asır Türk Şâirleri, II, 756-763; Ahmed Bâdî Efendi, Riyâz-ı Belde-i Edirne [haz. Niyazi Adıgüzel-Raşit Gündoğdu], II/I, 1082-1084; İshak Sunguroğlu, Harput Yollarında, I, 206213; Fikret Memişoğlu, "Elazığ’da Basın Hayatı", Yeni Firat, sy. 22 [İstanbul 1964], s. 21.)

36 Kemâleddin Efendi ikinci mısrâdaki "Tevfîk" kelimesini hem "Allah’ın yardımı, muvaffak olma" gibi mânâlarını hem de birlikte icâzet aldığı arkadaşı Çemişgezek Hamîdiye Medresesi müderrisi Tevfîk Efendi’yi kastederek kullanmıştır. Birinci mısrâda "iyi îhâmı da var” diye işâret ettiği husus budur. (İshak Sunguroğlu, Harput Yollarinda, II, 170-171).

37 Giritli Sırrı Paşa (v. 1313/ 1895) Kemâleddin Efendi’nin baba dostudur. Devlet adamlı̆̆ı yanında âlim oluşu ve şâirliği bakımından da XIX. asrın mühim zevâtındandır. Sırrı Paşa dönemin márûf ulemâsından Kemâleddin Efendỉnin babası Abdülhamîd Hamdî Efendi ile ilk zamanlarda gıyâben dost olmuştur. Sırrı Paşảnın vefâtına kadar süren yaklaşık 20 yıllık bu dostluktan Sırrı Paşa çok istifâde etmiş, ilmî eserlerini önce Abdülhamîd Hamdî Efendi'ye okutmuş, onun mütâlaa, tashihât ve muvâfakatından sonra neşretmiştir. Bağdat ve bilhassa Diyârbekir vâlilikleri esnasında Harput'a uğrayıp Abdülhamîd Efendi'yi ziyâret etmiş, 1894'te Diyârbekir vâlisi iken onu ve Kemâleddin Efendi'yi Diyârbekir’e davet etmiştir. Kemâledin Efendi Tesbîtü'l-mefhûm fî tahkikikit-tebe 'iyyeti beyne'l'ilmi ve'l-ma lûm adlı risâlesinde "Târihî, Edebî Bir Hikâye-i Hâl-i Mâzî" başlığı altında hem babası ile Sırrı Paşa arasındaki sıkı dostluğa hem de söz konusu ziyârete dâir şu satırları yazmıştır:

"Efâzıl-1 vülâtdan Giridî Sırrı Paşa ile peder-i muhteremim Harputî Hoca el-Hâc Abdülhamîd Hamdî Efendi Hazretleri’nin beyninde âdetâ aşk ve garâm derecesine varmış pek samîmî bir muhabbet-i hâlisa vardı. Hattâ Paşa’nın ba'zı suver-i Kur'âniyye’ye yazdıkları tefsîr-i şerîfler ba‘demâ üstâd-ı a‘zam tanıdığı Efendi Hazretleri’nin bir kere de nazar-1 tedkikk-i eser-i mû-şikâfâne ve tashîhinden geçmedikçe intişâr eylememek bir âdet-i ma'rûfe olmuşdu. Esâsen mükâtebe ile başlamış ve sûret-i gıyâbîde on yedi sene kalmış olan o incizâb-1 kalbî ve hubb-1 sahîh ü gyyâbî Paşa’nın ilk def'a Diyârbekir vâliliğine ta'yîninde Ma'mûretü'l-'azîz'den mürûru sırasında henüz şuhûdîye tahavvül edip senelerden beri hasretkeş-i telâkỉ olan o iki müştâk-1 fâzıl yek-dîgerinin rü’yet-i şahsıyla karîrül-'ayn olarak nímet-i vuslata nâil olabilmişdi. Müeahharan Diyârbekir'den Bağdad'a Bağdad'dan yine 


\title{
2. Kapladı mâtemi aktâr-ı cihânı zîrâ
} Göremez çeşm-i felek bir daha mislin heyhât

3. Yâd edip re'fet ü 'irfânını hep ağlarlar Cem'-i erbâb-1 edeb zümre-i ehl-i hâcât

4. Tarz-1 nev hâme-i i'câzı ile âlemde Nâm-1 hallâk-1 ma ânîyi kazanmışdı o zât

5. 'Arza muhtâc değil yazdığı tefsîrleri Âyet-i fazl ü kemâlin ediyor hep isbât

6. Mû-şikâfâne nazar-pâş olıcak Kur'ân'a Getirir vech-i zuhûra nice bin remz ü nikât ${ }^{38}$

\author{
7. Sırr-ı Tenzîl ile Furkān'ı Cenâb-1 Mevlâ ${ }^{39}$
}

Yâr u yâver kıla kendisine rûz-1 'arasât

\section{Hâdim-i Hazret-i Kur'ân idi yâ Rab olsun İbn 'Abbâs ile hem-sâye-i kasr-1 cennât}

Diyârbekir'e vâli olan müşârünileyh Diyârbekir'de hastalandı. İstanbul'a gitmeye me'zûniyet dahi alamadığından râhatı münselib, kalben muztarip olup edîbâne pek sûzişli mektûblar yazarak habîb-i lebîbi ve kendisince kalbî ıztırâbının en hâzık ve fâik bir tabîbi olan üstâdını Diyârbekir'e da'vet etdi. Rükûbu içün bizzât kendi paytonunu gönderdiği gibi 'azîmet ve 'avdeti esnâsında merâsim-i hürmetkârâne de yapdı, yapdırdı. 'Arabî üç yüz on bir ve Rûmî üç yüz on târîhinde idi ki şu sûretle da'vet-i vâkı'aya icâbet ve pek muhteşem bir hâlde Âmid'e âmed ü şüd etmekle en sevgili bir dostunun tatyîb-i kalbine mübâderet eden muhterem pederimin muğtenim bildiğim hizmet ve ma'iyyetinde arabaya râkiben Diyârbekir'e müteveccihen yola çıkdık. Esnâ-yı râhda müşârünileyh Hazretleri fakīre hitâben "Kemâl! Şu sefer-i nâgehân-zuhûr içün hâtırıma şimdi bir târîh geliyor. Ammâ ma'hûdun hilâfı olarak 'Arabî değil Rûmî oluyor. Ma 'lûm ya, târîhler dâimâ sene-i 'Arabiyye üzere tanzîm edilir." dedi,

Hamdî sevk etdi bizi Âmid’e dek sırr-ı kader 1310 [1894]

mısrâ'inı okudu. Hemân cevâben fakīr dahi "Efendim, müsâ‘ade buyurursanız bendeniz şu sûretle ikmâl edeyim." dedim. Bi'l-bedâhe:

Yazdı târîhini Rûmî olarak şimdi peder

Hamdî sevk etdi bizi Âmid’e dek sırr-ı kader

beytini okudum. Hasbeş-şefka kabûl ve istihsân buyurdular. Bu vech üzere cereyân eden şu küçük mükâleme-i edebiyyeyi mü’ehharan Paşa Hazretleri ile dîger zevât-1 münâsibeye 'arz ve beyân eylediğimiz zamân içlerinde "Bu da Hocaefendi Hazretleri’nin mes'ûdiyet ve bahtiyârlığı esbâbından biridir." diyenler de olmuşdu. Mecma'-1 fezâil olan o iki muhibb-i fillâhı Cenâb-1 Allah vâsıl-ı cinân, nâil-i kurb-1 Rahmân eylesin. Âmîn.”

(bk. Kemâleddin Harputî, Tesbîtü'l-mefhûm..., AÜDTCF Kütüphânesi, Mustafa Con Blm., nr. A/237, vr. 26ª-27ª Eser tarafımızdan bugünkü harflere aktarılmış, kaynak tespitleri yapılıp çeşitli notlar ilâve edilerek "Kemâleddin Harputî̉nin Tesbîtül-mefhûm fî tahkikit'tebe ‘yyeti beyne'l-'ilmi ve’l-ma 'lûm Adlı Kelâm Risâlesi” başlı̆ğyla yayıma hazır hâle getirilmiştir.)

Sırrı Paşa ile ilgili teferruatlı mâlûmat için bk. Cemal Kurnaz, "Sırrı Paşa”, DİA, İstanbul 2009, XXXVII, $127-129$.

38 İkinci mısrâdaki "vech-i zuhûr" terkîbi neșirde sehven olsa gerek "vech-i tuhûr/ tahûr" okunacak șekilde çıkmıştır.

39 Sırr-ı Tenzîl ve Sırr-ı Furkān Sırrı Paşa'nın tefsire dair eserlerinden ikisidir. Sırr-ı Tenzîl, onun Ahsenül-Kasas, Sırr-ı Furkān ve Sırr-ı İnsân adlı yine tefsirle alâkalı matbû eserlerinin özeti mâhiyetindedir. 1311/1894'te yazılan eserin bilinen iki yazması Süleymaniye Kütüphânesi, Esad Efendi Blm., nr. 177 ve Diyarbakır İl Halk Kütüphânesi, nr. 886'da bulunmaktadır. Sırr-ı Furkān ise Furkān Sûresi'nin tefsiri olup İstanbul'da basılmıştır $(1307,1312)$. 


\title{
9. Hâk-i gufrâne büründükçe Cenâb-1 Sirr1 Âfiyet üzre bulunsun şeh-i Fârûk-sıfât
}

\author{
10. Eşk-i pür-hûn ile târîhini nakş etdi Kemâl \\ Sırrı Paşa bu sene eyledi ifnâ-yı hayât ${ }^{40}$ \\ سرى ياشا بو سنه ايلدى افناى حيات
}

$1313(1895)^{41}$

11

\section{Mutavvel'e bed' ü mübâşeret olundukda 'âcizâne söylediğim târîhdir::22}

[Fâ‘ilâtün (fe'ilâtün) fe'ilâtün fecilün (fa'lün)]

\author{
1. Lutf u ihsânını Hak kıldı mezîd \\ Vâcib oldu bana şükr ü tahmîd
}

2. Vâlid-i mâcid [ü] hem üstâdım Anda cem` oldu bütün hulk-1 hamîd ${ }^{43}$

3. Kerr-i ezmân ile mümkün mü ola Asl-1 dîne bu gibi rükn-i meşîd

\author{
4. Dâniş ü fazlda mânendi 'adîm \\ Gelemez ka'bina hem İbn 'Amîd ${ }^{44}$
}

40 Kemâleddin Efendi bu mısrâı "Eyledi bu sene Sırrı Paşa ifnâ-yı hayât" şeklinde yazmış, Hazîne-i Fünûn imzalı dipnotta ise mısrâın takdîm-tehîrle yukarıdaki şekliyle yazılmasının daha selis olacağı ifade edilmiştir. Kemâleddin Efendi Hazîne-i Fünûn'a bu düzeltmeyle ilgili bir mektup yollamış, mektup derginin 4. cilt, 6. sayısında (22 Zilhicce 1313/ 4 Haziran 1896) "Harput'dan Derci Ricâsıyla Vârid Olmuştur” duyurusuyla yayımlanmıştır (s. 87-88). Kemâleddin Efendi’nin mektubu şöyledir: “Teşekkür ve İ'tizâr: Hazîne-i Fünûn'un el-hak tenvîr-i 'uyûn ve bütün müştâkān-1 'irfânı memnûn eyleyen tedkỉkāt-1 edebiyyesi cümle-i cemîlesinden olarak 37 numerolu nüshasındaki târîh-i nâçîaâneme ta'lîk eden mutâla'ası pek musîb olduğunu ma'a't-teşekkür tasdîk ve ikrâr ve hakỉkaten 'âcizleri de târîhin tanzîm ve takdîminden sonra muvaffak olduğum o mülâhazanın nasılsa sâika-i işgâl ile 'arz ve ihtârı husûsunda terâhî ve ihmâl eyledigimden 'alenen izhâr-1 nedâmet ve i'tizâr eylerim. Kemâleddin Harputî.”

41 Kemâleddin Harputî. Hazîne-i Fünûn, III/37 (13 Ramazân 1313/ 27 Şubat 1896), s. 392.

42 el-Mutavvel fi'l-méânî ve'l-beyân: Sa’deddin Teftâzânînin (v. 792/1390) Hatîb Kazvînînin (v. 739/1338) Telhîsüll-miftâh’ına yaptığı şerhtir. Aşağıda 14 numaralı kıt’ada da görüleceği üzere eser Şerh-i Telhîs olarak da anılırdı. Telhîsü'l-miftâh ise Ebû Yakub Sekkâkîye âit (v. 626/1229) Miftâhu'l-ulûm adlı kitabının belâğata dâir üçüncü bölümünün muhtasarıdır. Miftâhu'l-ulûm da Sekkâkînin sarf, nahiv ve belâğat olmak üzere üç bölümden oluşan meşhur kitabıdır. Medreselerde talebelerin seviyesine göre her üç eser de sirasıyla okutulurdu. Seyyid Şerîf Cürcânînin (v. 816/1413) Hâşsiye ale’l-Mutavvel'i de hocanın isteğine göre okutulan kitaplardandı.

43 Kemâleddin Efendi babası Abdülhamîd Hamdî Efendi’den bahsettiği bu beyitte son kelimeyi tevriyeli kullanmaktadir.

44 Ebü'l-fazl İbnü'l-Amîd'in asıl adı Muhammed b. Hüseyn el-Kummî olup h. IV. asırda yaşamış ve 360/970'de 
5. Bana başlatdı Mutavvel Telhîs

Bezl-i himmet ile bu sâl-i cedîd

6. Dü cihânda ola şâd ü mesrûr

Olmaya kaddi nevâible hamîd

7. Sâyesinde nice a'vâm u dühûr

Zindegânî ederim yâ Rab ümîd

8. Dedi cevher gibi târîh Kemâl

Ola itmâmı da bâ fazl-ı Mecîd

اوله إتتمامي ده بِ فضِل مجِدِ

$1305(1888)^{45}$

\section{$\underline{12}$}

\section{Babası Abdülhamîd Hamdî Efendi’nin vefâtı sebebiyle yazdığı târih:}

[Mefầilün fe'ilâtün mefầilün fe'ilün (fa'lün)]

1. Eyâ mekābir-i zâir olan gürûh-1 'ibâd

Edin şu merkad-i pâkin ziyâretin mu'tâd

2. Teessüf eyleyerek eşk-rîz olun her dem Yıkıldı çünki bu dîn içre bir metîn 'imâd

3. Risâle şârihi Abdülhamîd Efendi Hoca İmâm-1 A‘zam-1 asr iken ol kerîm-nihâd

4. Bu kabr-i pâke defin oldu ya'nî fevt olarak Umûma olsun İlâhî şefî‘-i yevm-i tenâd ${ }^{46}$

5. Kemâl yazdı teessürle çifte târîhin Birinci Rûmî olur mısrâ‘aynı kıl ta‘dâd

vefât etmiştir. İbnü’l-Amîd Büveyhî vezîrlerinden olmakla birlikte asıl şöhreti büyük bir âlim ve kuvvetli bir edîb olmasından kaynaklanmaktadır. Bilhassa eski dönem Arap şiiri, lugat, nahiv, arûz, Kur’an ilimleri, tefsir, fikıh, felsefe, hendese, astronomi gibi sâhalarda nâmından söz ettirmiş; aklî ve naklî ilimlere vukūfu hasebiyle "İkinci Câhız" olarak anılmıștır. (Ahmet Güner, “İbnü'l-Amîd", DİA, İstanbul 1999, XX, 486.)

45 Mecmûa, AÜ̇iF Kütüphânesi, Yazmalar Blm., nr. 36, s. 148 (Eser yazma olmasına rağmen varak değil sayfa esas alınarak numaralandırılmıștır).

46 İkinci mısrân sonundaki "yevm-i tenâd" ibâresinden kastedilen kıyâmet günüdür. Kur'ân-1 Kerîm’de "yevme’ttenâd” şeklinde geçmekte olan terkîb “feryâd ü figân günü” mânâsına gelmektedir. (Âyet için bk. el-Mü’min 40/32.) 
6. Peder Efendi bugün eyledi behiști mekân

Hemen cinân ile değişti cihân bir üstâd ${ }^{47}$

r. 1318 يدر افندى بوكون ايلدى بَشتى مكان

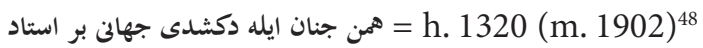

$\underline{13}$

\section{Babası Abdülhamîd Hamdî Efendi ile Diyarbakır’a yaptıkları yolculuk esnasında düşürdükleri târih:}

[Fâ'ilâtün fe'ilâtün fe'ilâtün fe'ilün]

Yazdı târîhini Rûmî olarak şimdi peder

Hamdî sevk etdi bizi Âmid’e dek sırr-ı kader

حمدى سوق ايتدى بزى آمده دك سر قدر

Rumî 1310 (m. 1894) ${ }^{49}$

$\underline{14}$

\section{Dîger (Mutavvel'i okumaya başladığı yıla düşürdüğü târihlerden biri): $:^{50}$}

[Mefầîlün mefầîlün fe ûlün]

Lehü'l-hamd lutf-1 Hak'la Şerh-i Telhîs ${ }^{51}$

Olundu bed' olsun tîzce ikmâl

Kemâl târîh-i cevher ferdi geldi

Mutavvel başladim hatm ola bu sâl

مطول باشله دم ختم اوله بِو سال $\underset{=}{=} 1304+1=1305(1888)^{52}$

47 İshak Sunguroğlu, Harput Yollarında, II, 161. Kemâleddin Efendi’nin bu gazeli babasının mezar taşına hakkedilmek üzere yazdığı anlaşılmaktaysa da mezarın bugünkü taşlarında bu gazel bulunmamaktadır.

$48 \mathrm{Bu}$ mısrâı Sunguroğlu "Haman cihanla değişdi cihanı bir üstad” şeklinde nakletmiştir. Ancak bu okuyuş hem mısrâda rekâket meydana getirmekte hem de ebcedin tutmamasına sebep olmaktadır. "Cihanla" kelimesini "cinân ile" şeklinde değiştirdiğimizde ise mânâ ve hesap tutmakta, ancak bu sefer de vezin aksamaktadır.

49 Birinci mısrâ Kemâleddin Efendi’nin, ikincisi Abdülhamîd Hamdî Efendi’nindir. Beytin hikâyesi için yk. bk. 37. dipnot.

50 Diğeri için yk. bk. 11 numaralı şiir.

51 Şerh-i Telhîs için yk. bk. 42. dipnot.

52 Mecmûa, AÜİF Kütüphânesi, Yazmalar Blm., nr. 36, s. 148. 
$\underline{15}$

\section{Harput'un Sâbık Belediye Reîsi Feyzî Beyzâde Mehmed Midhat Efendi'nin vefâtına târîh $:^{53}$}

[Fâ'ilâtün fe'ilâtün fe'ilâtün fe'ilün (fa'lün)]

1. Feyzî Beyzâde Efendi ki Muhammed Midhat

İştihâr etmiş idi belde-i Harput'ta tamâm

2. Hatm-1 enfâs ederek gitdi cihândan hayfâ

Kasr-1 cennetde İlâhî göre lutf u inâm

3. Geldi üçler dedi târîh-i vefâtın Kemâl

Feyzî Beyzâde bu sâl eyledi me’vâyı makām

فيضى بكزاده بو سال ايلدى مأوايى مقام

$1342+3=1345(1926)^{54}$

\section{6}

\section{Babası Abdülhamîd Efendi’nin vefâtı üzerine yazdığı ve mezar taşına hakkedilen târih manzûmesi:}

[Müstef'ilün müstef'ilün]

1. Ey zâir-i 'ibret-karîn

Bir zâtdı ki burda defîn

2. Abdülhamîd Efendi kim

Allâme-i asr-1 güzîn

53 Feyzî Beyzâde Efendi Harput'un eşrâfından bir zâttır. Babası varlıklı bir tüccar olduğu için temel eğitimden sonra tahsile devam etmemiş, onun işleriyle meşgûl olmuştur. Bir ara Anbar memurluğu yapmış, sonra Harput Belediye Reisliğinde bulunmuştur. Belediye reisiyken 1315/1897'de ekmeğe yapılan zamma isyân eden halk tarafından alaşağı edilen Feyzi Efendi bu isyanda canını zor kurtarmış, geri kalan hayatını kendi işleriyle meşgûl olarak geçirmiştir. (İshak Sunguroğlu, Harput Yollarında, II, 356.)

54 a.g.e., II, 356. Mehum Sunguroğlu, Kemâleddin Efendi’nin yazdığı târih mısrâını "1342+3= 1345" olarak açıkça hesaplamasına rağmen Beyzâde Mehmed Bey’in vefât târihini m. 1929 olarak vermiştir. Halbuki 1929’un hicrî karşılığ $1347-1348$ 'dir, 1345 ise m. 1926'ya tekābül etmektedir. 
3. Olduğu-çün mevti ile

Âlem umûm üzre hazîn

4. Târîhini yazdı Kemâl

Ağladı cümle mü'minîn

اغلدى جمله مؤمنين

$1320(1902)^{55}$

17

Târîh-i Cülûs[-1 Sultân Vahîdeddin] ${ }^{56}$

[Mefầîlün mefâ‘îlün mefâ‘îlün mefâcîlün]

1. Mưîn olsun Cenâb-1 Pâdişâh'a cümle kerrûbîn

Deyu eyler duâ ihlâs ile Müftî Kemâleddîn

2. Serîr-i şevketinde 'izz ü ikbâl üzre her bir hîn

İlâhî pâdişâhı [gâlib ü] mansûr kıl âmîn ${ }^{57}$

3. Deyüp de yazdı târîh-i cülûsun böylece zerrîn

Bu mâh şâh-ı cihân oldu Muhammed Hân Vahîdeddîn

بو ماه شاه جهان اولدى محمد خان وحيدالدين

$1336[1918]^{58}$

55 İshak Sunguroğlu, Harput Yollarında, II, 162. Bu manzûmenin hakkedildiği taş bugün Abdülhamîd Efendi'nin mezarının başında bulunmaktaysa da yazı aşınma ve oksitlenmeden dolayı maalesef okunamaz hâle gelmiştir.

56 Osmanlı'nın son sultânıdır. 1861'de doğmuş, 1926'da San Remo (İtalya)'da vefât etmiş, Şâm'a defnedilmiştir. 3 Temmuz 1918-1 Kasım 1922 târihleri arasında hüküm sürmüştür. Sultân Vahdeddin hayatı, padişahlık devresi, icrâatları, verdiği kararlar, Ankara Hükümeti'yle mücâdelesi, sürgünü, hâtırâtı ve vefâtı gibi hususlar bakımından en çok tartışılan Osmanlı sultânlarından biridir. (bk. Cevdet Küçük, "Mehmed VI”, DİA, Ankara 2003, XXVIII, 422-430.)

$57 \mathrm{Bu}$ mısrâda muhtemelen mürettib hatâsı sebebiyle bir kelime eksik kalmıştır. Mısrâı yukarıdaki ilâveyle yazdığımızda vezin düzelmektedir.

58 Ma‘mûretü'l-'azîz vilâyeti merkez müftîsi Kemâleddîn. Cerîde-i Sûfiyye nr. 148 (22 Zilka'de 1336/ 29 Ağustos 1918), s. 462. 
$\underline{18}$

\section{Ma'mûretü’l-azîz Hamidiye İdâdîsi’nin İnşâsına Yazdığı Târih:59}

[Mefâ‘îlün mefâ‘îlün mefầîlün mefầîllün]

1. Cihân-bân-1 mu'azzam Hazret-i 'Abdülhamîd Han kim

Zamân-1 sa'di behcet-bahşdır erbâb-1 âmâle

2. Hemân i'lâ-yı dîne sarf eder fikr-i hümâyûnun

Müceddiddir sezâdır süddesi her dürlü iclâle

3. Ziyâ-pâş-1 maârif oldu şems-i himmeti dehre

Hilâl-i kadrin eyler sa'y herkes şimdi ikmâle

4. Güzel tarz üzre ez-cümle bu zîbâ mektebi Vâlî

Hasan Beg sâye-i lutfinda himmet kıldı a'mâle ${ }^{60}$

5. O vâlî-i merâhim-pîşe lutf-endîşe kim etdi

Tefevvuk istikāmet 'iffet ü re'fetle emsâle

6. Mü’ebbed kıla Mevlâ pâdişâhın şevket ü şânın

Fürûğ-1 devleti fer vere dâim mülk ü ikbâle

7. İki destin duâya kaldırup evvel de târîhin

Zehî bir mekteb-i ídâdî inşâ oldu etfâle

زهى بر مكتب إعدادى انشا اولدى اطفاله

$1305-2=1303(1885)^{61}$

59 Manzûmenin kayıtlı olduğu yazmada başlık yoktur. Yaptığımız araştırmalarda o târihlerde inşâ edilen mektebin kısaca Hamidiye veya Mülkiye İdâdîsi olarak anılan "Ma'mûretü’l-azîz Mekteb-i İdâdî-i Hamîdiyye-i Mülkiyye-i Şâhâne" olduğunu tespit ettik. Kendisi de bu mektep mezunu olan merhum Sunguroğlu okulunun fizikî yapisı, hocaları, dersleri, talebeleri, imtihânları vs. hakkında kıymetli bilgiler vermektedir. Teferruatı için bk. İshak Sunguroğlu, Harput Yollarında, II, 65-75.

60 Hacı Hasan Refîk Bey (Ma‘mûretü’l-azîz vâliliği 1883-1889). bk. 1302 Sene-i Hicriyyesine Mahsûs Sâlnâme-i Vilâyet-i Ma'mûretü'l-azîz, Vilâyet Matbaası, ty., s. 48.

61 Mecmûa, AÜİF Kütüphânesi, Yazmalar Blm., nr. 36, s. 148. 


\section{Kızı Fatma Râşide Hanım’ın doğumuna düșürdüğü târih:}

[Fâ'ilâtün fấilâtün fầilün]

Söyledim târîhini cevher gibi

Râşidemiz doğdu mehd-i '̂aleme

راشده مزٍ طوغدى مهد عالمه =

$1317(1900)^{62}$

$\underline{20}$

\section{Harputlu Şâir Kanbalakzâde Abdülhamîd Hazmî Efendi’nin vefâtına yazdı̆̆ı târih: ${ }^{63}$}

[Müstef'ilün müstef'ilün müstef' ilün müstef'ilün]

1. Abdülhamîd Hazmî Efendi muhterem bir zât idi Hikmetler etdi sıdk ile cidden bu mülk ü millete

2. Kâmil edîb olduğu-çün kāl u kalemle her zamân Bezl-i himem eyler idi nef'-i umûma hizmete

3. Hüsn-i hisâl-i pâk ile ilm ü edeb bâbında da Hayrân idi ehl-i kalem gösterdiği ehliyyete

4. Zehr-âb-1 mevti nûş edip eyvâh fevt oldu bu sâl Mağfûr olup mazhar ola yâ Rab cemâl-i Hazret’e

62 Mecmûa, AÜİF Kütüphânesi, Yazmalar Blm., nr. 36, s. 149. Fatma Râşide Hanım’la ilgili teferruatlı bilgi için bk. Ahmet Karataş, "Harput Ulemâsından Müderris-Müftü Mehmed Kemâleddin Efendi”, s. 111-112.

63 Kanbalakzâde Hacı Abdülhamîd Hazmî Efendi 1272/1856'da Harput’ta doğdu. Şehrin diğer büyük hocalarının yanısıra Kemâleddin Efendỉnin babası Abdülhamîd Hamdî Efendi’en de ders aldı. Çeşitli devlet kurumlarında kâtiplik yaptıktan sonra iki dönem Harput Belediye reisi oldu. El'azîz Rüşdiye’sinde imlâ hocalığı, Harput Dârü’lhilâfe'sinde Türkçe, edebiyat, malûmât-1 hukūkiyye muallimliği, Harput İmam Hatip Mektebi'nde Türkçe hocalığ1 vazifelerinde bulundu. İmâm Efendi’nin [Osman Bedreddin, v. 1343/1924] müridlerinden olan Hazmî Efendi Kemâleddin Efendi’nin de yakın arkadaşlarındandı. Beş çocuğundan dördünün kendisinden önce vefât etmeleri, büyük bir iştiyâkla bağlı olduğu şeyhinin vefâtı, Harput’ta ulemânın maruz kaldığı baskılar vs. sebeplerle 1928'de Mısır'a hicret etti ancak orada da kalamadı, aynı yıl Harput'a döndü ve burada vefât etti. Araştırmacılar onun mütevâzı, ahlâk-1 hamîde sâhibi bir zât ve kuvvetli bir şâir olduğu hususunda müttefiktirler. bk. İshak Sunguroğlu, Harput Yollarında, II, 292-298; M. Naci Onur, Harputlu Dîvân Şâirleri, Elazı̆̆ [1988], s. 80-84; Hayrettin Ayaz, Dîvân: Harputlu Abdülhamid Hazmî, İstanbul 1998, XI-XIX. 
5. Târîh-i tâmmın söyledi Müftî Kemâleddin hemân

'Azm eyleyip gitdi bu yıl Hazmî Efendi cennete

عزم ايليوب كيتدى بو ييل حزمى افندى جنته

$1346(1928)^{64}$

21

Büyük oğlu Ömer Naîmî Efendi’nin doğumuna düşürdüğü târih:

[Mef' ûlü fấilâtün mef' ûlü fấilâtün]

Yazdım Kemâl târîh hamd eyleyüp Hudâya

Mahdûm Ömer'ademden bezme vücûda geldi

مخدوم عمر عدمدن بزمه وجوده كلدى

$1309(1892)^{65}$

22

\section{Ablalarından birinin vefâtına düşürdüğü târih:}

[Mef'îlü mefấîlü mefâ‘îlü fe'îlün]

Bir âh ile cevher gibi târîhini yazdım

Lâyık idi ki hemşîremiz cennete gitdi

لايق ايدي كه همشيره مز جنته كيندى

$(1310+1=1311 / 1893-1394)^{66}$

64 Manzûme için bk. M. Naci Onur, Harputlu Dîvân Şâirleri, s. 80-84.

65 Mecmûa, AÜİF Kütüphânesi, Yazmalar Blm., nr. 36, s. 149. Ömer Naîmî Efendi hakkında bilgi için bk. Ahmet Karataş, "Harput Ulemâsından Müderris-Müftü Mehmed Kemâleddin Efendi”, s. 104-110.

66 Mecmûa, AÜİF Kütüphânesi, Yazmalar Blm., nr. 36, s. 149. Kemâleddin Efendi’nin Nâfia, Tâhire ve Ayşe adında ablaları vardır (Mecmûa, AÜİF Kütüphânesi, Yazmalar Blm., nr. 36143, vr.nr. yok). Sunguroğlu, Tahire Hanım’ın Han (merkez Hankendi köyü) ağalarından Mehmed Ağa ile, Ayşe Hanım’ın da Hoğu ağalarından Mustafa Ağa ile şatafatlı düğ̈̈nler yapılarak evlendirildiğini söyler (Harput Yollarında, IV, 40-41). Kemâleddin Efendi’nin vefât kaydının bu üç abladan hangisine âit olduğunu bilmiyoruz. 
23

\section{Küçük oğlu Abdülhamîd Hamdî Efendi’nin doğumuna düşürdüğü târih mısrâı:}

[Mef' ûlü fâ'ilâtü fâ'ilâtü fâ'ilün]

'Abdülhamîd Efendi nâmı avdet etdi

عبد الحميد افندى نامى عودت ايتدى

$1320(1902)^{67}$

24

\section{Torunu Müfîde'nin doğumuna düșürdüğü târih:}

[Mefâ‘ilün fe‘ilâtün mefâ‘ilün fa'lün]

Yeni hafîdeme târîh yazdılar üçler

Müfîde Hânım’ Rabbim bize 'atâ kıldı

مفيده خانمى ربم بزه عطا قيلدى

$1330+3=1333(1915)^{68}$

\section{5}

\section{Ağabeyi Saîd Efendi'nin vefâtına yazdığı târih: ${ }^{69}$}

[Müstef'ilün fe'ûlün müstef'ilün fe'ûlün]

1. Vâ'izlerin hakikat olmuşdu ercümendi

Fevt oldu gitti hayfâ Hâcı Sa îd Efendi

67 Mecmûa, AÜİF Kütüphânesi, Yazmalar Blm., nr. 36143, vr. nr. yok. Âile içinde "Küçük Efendi” olarak anılan Abdülhamîd Hamdî Efendi hakkında bilgi için bk. Ahmet Karataş, a.g.m., s. 112-113.

68 Ömer Naîmî Efendỉnin kızı olup çocuk yaşta vefât etmiştir. Mecmûa, AÜİF Kütüphânesi, Yazmalar Blm., nr. 36143, vr. nr. yok.

69 Saîd Efendi’nin tam adı Mehmed Saîd Mansûr'dur. Babası Abdülhamîd Efendi'nin kaydına göre 25 Rebîu’l-âhir 1274/ 13 Aralık 1857'de dünyaya gelmiştir. Harput'un önde gelen şâirlerinden Hoğulu Rahmî Efendi doğumuna şu manzûmeyle târih düşürmüştür:

Şükr Mevlâyya bu şeb lutf-1 Hudâ etdi zuhûr

Matla'-1 burc-1 saâdetde zuhûr eyledi nûr

Hamd ola Hamdî Efendi’ye verip Hazret-i Hak

Ya'nî bir hayr-1 halef tıfl-ı zekiyy-i Mansûr

Kurretü'l-'ayn-i eb ü ceddi olup gevher-i pâk

Dîdeler rûşen olup oldu gönüller mesrûr 


\section{Fitrî letâfetiyle meşhûr-1 âlem idi Ne kimse ona benzer ne başkasına kendi}

\section{Zâhirde lâubâlî zannedilirdi lâkin \\ Bâtında hissemendi idi esrâr-1 fendi}

Cedd-i a lâsını hem-nâmı olup şâd etdi (Büyük dede Muhammed Saîd Efendi’ye atıf vardır.)

Vâris-i 'ilm ü kemâli ede ol Rabb-1 Gayûr

Çâr-yârin mededi ile denildi târîh

'Ömr-i sermedle emîn ola Muhammed Mansûr

عمر سرمدله امين اوله محمد منصور

$(1270+4=1274 / 1857)$

(Mecmûa, AÜIF Kütüphânesi, Yazmalar Blm., nr. 36, s. 147; Mecmûa, AÜİF Kütüphânesi, Yazmalar Blm., nr. 36143, vr.nr. yok).

Saîd Efendi, tahsilini Kâmil Paşa Medresesỉnde babasından ders alarak ikmâl etmiş, Sâre Hatun (Sarahatun) Medresesi müderrisliğine atanmıștır. Esas şöhretini Sâre Hatun Camii’nde yaptı̆̆ı tesirli vaazlarla elde eden Saîd Efendi çeşitli memuriyetlerin ardından 1913-1918 döneminde Elaziz mebusu olarak vazife yapmıştır. Merhum Sunguroğlu’nun kaydına göre âlim, fâzıl, natûk, nüktedân, hazırcevap, șen ve șâtır bir zât olan Saîd Efendi Harput'ta "Hacı Efendi" hattâ daha çok "Deli Hacı" olarak anılırdı. Saîd Efendi İstanbul'un 8 Safer 1337/ 13 Kasım 1918'te işgâli üzerine Halep üzerinden Harput’a dönmüş, "sultânü'l-vâizîn" olarak camilerde va'z u nasihatlerine devam etmiştir. Sesi gür ve tesirli olduğundan resmî günlerde ve çeşitli merasimlerde yapılması gereken nutuk ve duâ vazifesi ona tevdî edilirdi. Saîd Efendi’nin son yılları yokluk, hastalık ve ızdırapla geçmiştir. Âilenin başına gelen felâketlerden (kardeşi Kemâleddin Efendỉnin azli ve sürgünü, âilenin asırlık akarlarına el konulması, toprakların elden gitmesi vs.) oldukça etkilenmiş ve 28 Rebiül'l-âhir 1345/ 4 Kasım 1926'da 70 yaşında vefât etmiștir. Kemâleddin Efendi sürgün sebebiyle Samsun'da olduğundan ağabeyinin cenâzesinde bulunamamış ancak yukarıdaki târih manzûmesini yazmış ve bu manzûme ağabeyinin mezar taşına hakkedilmiştir. Ayak tarafında olduğunu zannettiğimiz o mezartaşı bugün ne yazık ki yerinden kopmuş, bilâhere mezardan bağımsız olarak toprağa yerleştirilmiş ve üzerindeki yazı da silinmiştir. Baş kısmındaki şâhidede ise şu ibâre bulunmaktadır: "Yâ Gaffâr. Kasîde-i Bürde șârihi merhûm Ömer Na'îmî Efendi ahfâdından Sultânü'l-vâizîn meb'ûs-1 esbak el-Hâc Mehmed Sa îd Efendi merhûmun rûhuna Fâtiha - 1345." Said Efendỉnin bugüne intikāl etmiş bir eseri yoktur. Sunguroğlu da bu konuda mâlumat vermemektedir.

Enver Paşa yönetimindeki Osmanlı Hükûmeti 9 Cemâziye'l-âhir 1333/ 24 Nisan 1915’te bütün vilâyetlere gönderdiği bir tebliğ ile Ermeniler'le ilgili alınan bir dizi kararın uygulanmasını istemiști. Bu kararları kapsayan kanun bilâhere Tehcir veya resmî adıyla Sevk ve İskân Kanunu olarak adlandırılacaktır. Dâhiliye Nâzırı Talat Paşanının emriyle bu kanunun en sıkı uygulandığı yerlerden biri de Mamuretü'l-azîz'dir. İstanbul'un işgâlinden sonra mütâreke kuvvetleri Divân-1 Harb-1 Örfì (Savaş Suçları Mahkemesi) tesis ederek sevkiyât esnasında Ermeni kafilelerin korunmadığı, onlara zulmedildiği, haksız yere öldürüldükleri, emvâl-i metrûkenin talan edildiği gibi gerekçelerle devrin bazı siyâsîlerini ve bürokratlarını yargılamışlardır. Mamuretü'l-azîz tehciri dâvâsında yargılananlar arasında Saîd Efendi de vardır. Dâvâ 2 Zilka'de 1337/ 30 Temmuz 1919'da İstanbul'da görülmeye başlamıştır. Sanıklardan Meb'us Hacı Said Efendi ile Safvet Efendi'lerin dâvâ dosyaları o esnâda Harput'ta olmaları hasebiyle İstanbul'a getirilmeleri uzun zaman alacağından ayrılmıştır. Yargılamalar 21 Rebîü'l-âhir 1338/ 13 Ocak 1920'de tamamlanmış, verilen kararların bir kısmı 19 Cemâziye'l-evvel 1338/ 9 Şubat 1920'de Takvîm-i Vekāyîde neşredilmiştir. (Bu mesele hakkında daha teferruatlı bilgi için bk. Ferudun Ata, İsgal İstanbulunda Tehcir Yargılamaları, Ankara 2005, s. 8-17; 231-235. Saîd Efendi'nin hayatı hakkında bk. İshak Sunguroğlu, Harput Yollarında, II, 163-168).

Said Efendi öteden beri bürokrasinin içinde bulunduğu ve memleket meseleleriyle haşir neşir olduğu için siyâsî/ ictimâî hâdiselere bağımsız kalmamıştır. Bunun örneklerinden biri aralarında kendisinin de bulunduğu Elaziz'in eşrâf ve ulemâsından bir grupla birlikte İtisâm Mecmûasinın nâşiri Ahmed Şîrânîye (v. 1361/ 1942) o sıralar oldukça tartışılan Turancllık cereyanına karşı İslâmcılığı savunan, içinde "Biz Türküz lâkin dînimizi, dilimizi hâşâ ne Türklüğe ne de dinsiz bir kavmiyyete değişmeyiz!" gibi cümlelerin bulunduğu bir telgraf göndermesidir. Ahmed Şirânî mecmûanın 54. sayısında (17 Rebiülevvel 1338/ 10 Aralık 1919) “Harput’tan Bir Telgraf” başlı̆̆ıyla bu telgrafı neşretmiş, bir sonraki sayıda da (24 Rebîülevvel 1338/ 17 Aralık 1919) telgrafı müsbet bir şekilde teferruatlıca değerlendirmiş ve Harput heyetine teşekkür etmiştir. 
4. Yazdım Kemâl çıkdı bir mısrâ‘ ile târîh

Cennetde 'Adn'e gitdi Hâcı Sa'îd Efendi

جنتده عدنه كيتدى حاجى سعيد افندى

$1346-1=1345(1926)^{70}$

c) Kisa Manzûmeler

$\underline{26}$

[Fâ'ilâtün fe'ilâtün fe'ilün (fa'lün)]

1. Kâmil oldu sebeb-i mahv-i Kemâl

İstemiş böyle demek Rabb-1 Celâl

2. Hangi cürmümdü ki darıtdı seni

Sâhil-i bahre kadar atdı beni

3. Etdi âlemlere rüsvâ beni Hak

Bu da bir cilve-i Hak'dır mutlak

4. Tevbe etdim sana yâ Rab tevbe

Yeter oldu bana mesken kulübe ${ }^{71}$

27

[Fe'ilâtün (fâ‘ilâtün) fe'ilâtün fe'ilün]

1. Vermeseydi bize miknet Allâh İşlemek mümkün olur muydı günâh

2. Fakat ondan diye tuğyân etmek Uyamaz şart-1 'ubûdiyyete pek

3. Yine müstağfir olup da diyelim Biz kusûr etdik İlâhî n’idelim ${ }^{72}$

70 İshak Sunguroğlu, Harput Yollarında, II, 168.

71 Kemâleddin Efendi’nin Samsun'da sürgündeyken yazdığı şiirdir. (Mecmûa, AÜİF Kütüphânesi, Yazmalar Blm., nr. 36, s. 98). Kemâleddin Efendi’nin bahsettiği "Kâmil"in kim olduğunu tespit edemedik.

72 Kemâl. Mecmûa, AÜİF Kütüphânesi, Yazmalar Blm., nr. 36, s. 8. 


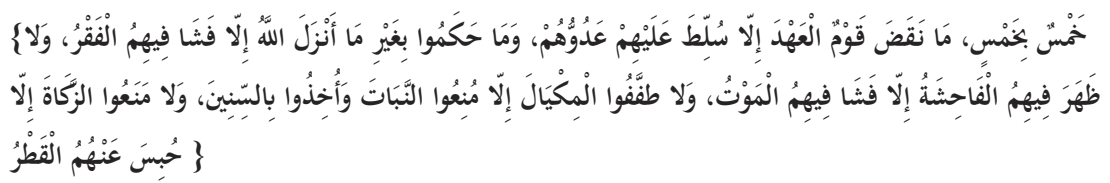

"Beş şey, beş şeye sebep olur. Ahdi bozmak düşman musallat olmasına, Kur'an’a aykırı hüküm vermek fakirliğe, fuhşun ortaya çıkması ölümlerin artmasına, ölçü ve tartıda eksiklik kıtlığa, zekâtın verilmemesi kuraklığa." hadîsinin nazmen tercümesi:

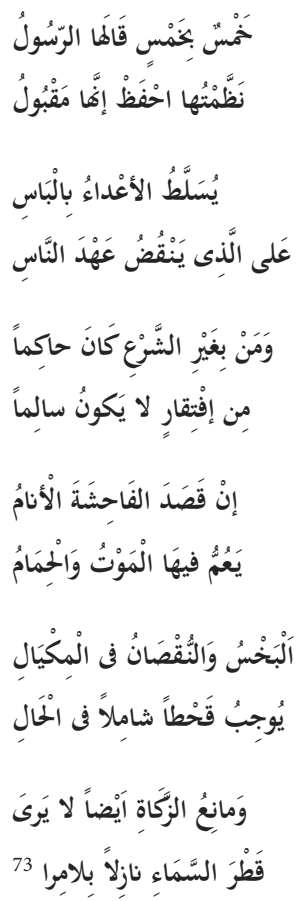

73 Kemâl. Hadîs-i şerîfin kaynakları için bk. Taberânî, el-Mu'cemü'l-kebîr (thk. Hamdî Abdülmecîd es-Selefî), Beyrut 1984, XI, 37 -38 (hadis nr. 10992); Süyûtî, el-Câmi'u’s-sağîr, AÜİF Kütüphânesi, Yazmalar Blm., nr. 36447, vr. nr. yok. Kemâleddin Efendi bu hadîsi yukarıdaki Arapça manzum açıklamasıyla birlikte Rekāik: Hadîs-i Erbaîn Risâlesi adlı eserine kaydetmiştir. Manzum açıklama bir yazmada daha kayıtlıdır. (Mecmûa, AÜİF Kütüphânesi, Yazmalar Blm., nr. 38182, vr. nr. yok.) Buradaki kayıtta son mısrâdaki "بلامتراء" șeklindedir. Manzûmenin tercümesi şöyledir:

[1] Peygamber Efendimiz’in beş şey ile beş şeyin meydana geleceğine dâir sözünü nazmettim. Ezberle! Çünkü makbûl olanı budur. [2] İnsanlara verdiği sözde durmayana düşman fitne salacak (ortalığı karıştıracak) bir şekilde musallat olur. [3] Şerî́atin hilâfına hükümler veren kendini fakirlikten kurtaramaz. [4] Allah’̉n yasakladığı şeye (fuhşa) yönelen halkın arasında ölüm kol gezer. [5] Ölçü ve tartıda eksiklik kıtlığa yol açar. [6] Zekâtını vermeyen de gökten bir damla yağmur yağdığını göremez.

bk. Ahmet Karataş, "Harput Ulemâsından Müderris-Müftü Mehmed Kemâleddin Efendỉnin Rekāik: Hadîs-i Erbaîn Risâlesi”, Marmara Üniversitesi İlâhiyat Fakültesi Dergisi, sy. 48 [İstanbul 2015], s. 77-78). 


\section{d) Gazeller}

[Fâ'ilâtün fe'ilâtün fe'ilâtün fe'ilün (fa'lün)]

1. Sa'y-i tahsîl-i emel mâni'-i kâm oldu bana

Nâ-murâd olma dahi gayri murâd oldu bana

2. Nûr-1 aynım sana etmem bunu etsem de helâl

Hasret-i çeşmin ile hâb harâm oldu bana

3. Ben de düşdüm heves-i âlem-i âba nâçâr

Gerdiş-i câm-1 safâ halka-i dâm oldu bana

4. Âh ki sen gibi âhûyı şikâr edemedim

Yohsa çok murg düşüp dâmıma râm oldu bana

5. Câmi'-i aşk-1 ruh-1 yâre duhûlümde Kemâl

Kûhken kāmet edip Kays imâm oldu bana ${ }^{74}$

30

\section{Rüsûmât Mümeyyizlerinden Hüseyin Vassâf Bey'in Sefîne-i Evliyâ-yı Ebrâr Nâmındaki Eserine Yazılmıș Takdîrnâme: ${ }^{75}$}

[Fâ'ilâtün fấilâtün fâ‘ilâtün fâ‘ilün]

1. Hidmet-i ebrârı îfâ eyleyüp Vassâf Beg

Bir Sefîne yapdı ki râğı olan memnûn olur

2. Şübhesiz mersâ-yı kurb-1 Hakk'a vâsıfdır o zât

Rütbe-i 'ulviyyeti gitdikçe de efzûn olur

74 Kemâleddin Efendi bu gazeli büyük oğlu Ömer Naîmî Efendi 1928'de Sandiklı'da savcı iken onun hasretiyle yazmıştır (bk. Süleyman Ateş, Bir Ömür Böyle Geçti, İstanbul ty., I, 106-107).

75 Hüseyin Vassâf Efendi: 1288/1872'de İstanbul'da doğdu. Resmî eğitim hayatını müteâkip Rüsûmât Emâneti Evrak Kalemi’nde işe başladı. Çeşitli kademelerde kâtiplik, müdürlükler yaptı. İstanbul Rüsûmât başmüdürü iken emekli oldu. Hüseyin Vassâf Efendi Uşşâkî dergâhında seyr ü sülûkunu tamamlamış bir mutasavvıf ve bir tasavvuf târihçisidir. Büyük emekler sarfederek 1925'te tamamladığ Sefîne-i Evliyâ-yı Ebrâr adlı eseri günümüzde tasavvuf araştırmacılarının en önemli kaynakları arasında yer almaktadır. Eser Mehmet Akkuş ve Ali Yılmaz tarafından bugünkü harflere aktarılarak neşredilmiştir (İstanbul 2006). 30'un üstünde eseri bulunan Hüseyin Vassâf Efendi 1929'da İstanbul'da vefât etmiş, Rumelihisarı Kabristanı'na defnedilmiştir. Daha teferruatlı bilgi için bk. Cemal Kurnaz-Mustafa Tatc1, “Hüseyin Vassâf”, DİA, İstanbul 1999, XIX, 18-19. 
3. Dest-i ta'zîme gelince o kitâb-1 müstetâb

Kalbimiz bir hiss-i rûhânî ile meşhûn olur

4. Çok teşekkür eyleyüp hasbî duâa eyler Kemâl

Gâibîdür bu dưâ ihlâsa da makrûn olur

5. Yâ Rab irfânda senâver ola Vassâf'ın senin

Bahr ü berr üstündeki mâdâm şu gerdûn olur ${ }^{76}$

31

[Mef'îlü mefầîlü mefâ‘̂̂lü fe'îlün]

1. İsneyniyeti ref' eyledi âgâh olan âdem

Dilbeste-i vahdetde fi'llâh olan âdem

2. Mihmân olarak nevbet ile zât ü sıfâta

Feyz-i ezel-i fitrîye hem-râh olan âdem

3. Varlık sıfatın yokluğa tercîh ediverdi

Maksûdı gibi kendisi bî-gâh olan âdem

4. Geçmekde muhâl olduğını anladı birden

Sahrâ-yı sivâ-zârda gümrâh olan âdem

5. Noksânı Kemâl eyledi hakkıyla idrâk

Dünyâsı da 'ukbâsı da Allâh olan âdem ${ }^{77}$

76 Mecûma, AÜİF Kütüphânesi, Yazmalar Blm., nr. 38182, vr. nr. yok.

77 Cerîde-i Sûfiyye, nr. 24/10 (10 Zilhicce 1330/ 20 Kasım 1912), s. 8.

Kemâleddin Efendi’nin dostlarından Harputlu Abdülhamîd Hazmî Efendi’nin de "olan âdem” redifli bir gazeli vardır. Hangi gazelin nazîre olduğunu tam olarak bilemiyorsak da Hazmî Efendi’nin gazelindeki son beyitte geçen "kemâl" kelimesinden onun Kemâleddin Efendi’nin gazelini tanzîr ettiği neticesini çıkarabiliriz. Söz konusu gazel şöyledir:

1. Gayriyyeti ref‘ etti Hudâ-hâh olan âdem Vahdetgeh-i üns içre ma'allâh olan âdem

2. Gördü bu merâyâda olan zât ü sıfâtı Mihmân-1 nihân-hâne-i dergâh olan âdem

3. Sildi harem-i dildeki evsâf u vücûdu Yokluktaki bu zevkden âgâh olan âdem

4. Attı bu sivâ nakşını ser-safha-i dilden Her bir nefesi âh olan Allâh olan âdem

5. Bî-şüphe ki Hazmî yetişir evc-i kemâle

Bedrî gibi bir kâmile hem-râh olan âdem

("Bedrî” Kemâleddin ve Hazmî Efendilerin şeyhi olan İmam Efendi’nin mahlasıdır. Hayatı hakkında bilgi için aş. bk. 98. dipnot.) (Gazel için bk. Hayrettin Ayaz, Dîvân: Harputlu Abdülhamid Hazmî, s. 196; Bekir Çöl, 


\title{
De'âvî Nâzırı Selâmî Tâhir Bey'in Gazeline Bir Nazîredir: ${ }^{78}$
}

\author{
[Fe'ilâtün (fấilâtün) mefấilün fe'ilün (fa'lün)]
}

\section{Cilvegâh-1 melâhat olmuşsun Mefharet-bahş-1 fitrat olmuşsun}

2. Devre-i hüsni ân-be-ân dolaşıp Ay gibi sen de âyet olmuşsun

\section{Senden alındı bunca zîb ü cemâl Mâyedâr-1 letâfet olmuşsun}

\section{Sana meftûn olur gören âdem Dâne-i hüsn-i hilkat olmuşsun}

\section{Yaralandım yeter ciğer-pârem Yine ma'rûz-1 hiddet olmuşsun}

"Buluntu Cönk”, https://sivasbekircol.wordpress.com /2011/05/15/buluntu-conk. Bekir Çöl, hususî kitaplığında bulunan bir cönkü bugünkü harflere aktararak internetteki şahsî sayfasında (blog) neşretmiştir. Ancak bu neşir okuma ve bilgi yanlışlarıyla doludur. Hazmî hakkında verilen bilgiler de gazelin şâiri olan Harputlu Abdülhamîd Hazmî Efendi'ye âit değildir. Hayrettin Ayaz neşrinde gazelin ilk kelimesi sehven "gayreti” şeklinde okunmuştur.)

78 Kemâleddin Efendi’nin Selâmî Tahir Bey diye kaydettiği zât Mehmed Tâhir Selâm Bey (v. 1260/1844)'dir. Uzun müddet sadâret mektupçuluğunda bulunduğu için Mektupçu Tâhir olarak da bilinen Tâhir Selâm Bey çavuşbaşılık, muhâsebecilik, rûznâmçecilik gibi vazifelerde de bulunduktan sonra 1258/1842'de Deâvî Nâzırı olmuş, bir yıl sonra azledilmiştir. Kudûrî, Makāmât-ı Harîrî ve Mîzânül-edeb'in tercümelerini yapmıștır. Ayrıca Dîvân', Münşeât'ı ve Semere-i Nihâl adlı eseri bulunmaktadır. (bk. Fatin Dâvûd, Hâtimetü̉l-eşâr [haz. Ömer Çiftçi], s. 227; Bursalı Mehmed Tâhir, Osmanlı Müellifleri, İstanbul 1342, 299; İbnülemîn, Son Asır Türk Şâirleri, III, 16831685.)

İbnülemîn Mahmud Kemâl Bey, Tâhir Selâm Bey’in vefâtından 64 yıl sonra (1325/1908) bir gün onun “...olmuşsun” redifli gazelinin ilk iki beytini duyunca şiir çok hoşuna gitmiş ve duyduğu iki beyitten hareketle o sıralar henüz tamâmını görmediği gazele nazîre yazmış, etrâfındaki şâirlere de nazîreler yazdırmıştır. Bilâhere gazelin tamamını bulan İbnülemîn bu hikâyeyle birlikte gazeli de Son Asır Türk Şâirleri’ne almıştır. Kemâleddin Efendi’nin de tanzîr ettiği gazel şöyledir:

1. Gül gibi pür tarâvet olmuşsun Reng ü bûdan ibâret olmuşsun

2. Seni ey nev-nihâl görmeyeli Büyümüş serv-kāmet olmuşsun

3. Sende evvel yok idi bu vahşet Şimdi âhû-tabîat olmuşsun

4. Bir nigâh etmiyorsun uşşâka Hele pek bî-mürüvvet olmuşsun

5. Hâl ü kālinden anladım ki Selâm Mazhar-1 feyz-i izzet olmuşsun

(İbnülemîn, Son Asır Türk Şâirleri, III, 1685. Tâhir Selâm Bey’in dîvânının Millet Kütüphânesi’nde bulunan nüshasında [Alî Emîrî Manzum, nr. 212] 4. beyit "Hîç nigâh etmiyorsun..." şeklinde başlamaktadır [bk. vr. 15b].) 


\title{
6. Seni incitmesin şu nâlişler \\ Bir mücessem nezâket olmuşsun
}

\author{
7. Ne bu âh u enîn Kemâleddîn \\ Sanki nevmîd-i vuslat olmuşsun ${ }^{79}$
}

33

[Mefầilün fe'ilâtün mefấi ilün fe'ilün (fa'lün)]

\section{Ârif Hikmet Bey'in gazeline zamânımızdaki ahvâle muvâfık bir sûretde yazdığım bir nazîredir: ${ }^{80}$}

\section{Kalem vekāi'-i devrâna tercümân olalı Sahâif üstüne âverde-i beyân olalı}

79 Merhum İshak Sunguroğlu beş beytini kitabına aldığı bu nazîreyi Kemâleddin Efendi’nin Hüseyin Vassâf Bey'in bir gazeline yazdığını söylemekteyse de Kemâleddin Efendi şiirin baş tarafına yukarıya aldığımız kaydı düşmüştür. bk. Mecûma, AÜIF Kütüphânesi, Yazmalar Blm., nr. 38182, vr. nr. yok. (Sunguroğlu’nda matla'in ikinci mısrâındaki "fitrat" kelimesi "fikret" șeklinde. a.mlf., Harput Yollarında, II, 174-175.)

80 Hersekli Ârif Hikmet Bey (v. 1321/ 1903) Mostar'da doğmuş, tahsilinden sonra zabıt kâtipliği, mümeyyizlik, Hukuk Dâiresi reisliği, çeşitli mahkemelerde başkanlık ve âzâlık gibi vazîfelerde bulunmuştur. "Encümen-i Şuarâ" topluluğunun önde gelen şâirlerinden biri olan Ârif Hikmet Bey âdetâ nazîreler şâiridir. Nâilîye yirmi dokuz, Fehîm’e on altı nazîresinin bulunması, Neşâtî, Vecdî, Güftî, Nâbî, Nedîm gibi şairlere bir çok nazîre kaleme alması bunu göstermektedir. (Hayatı ve eserleri hakkında teferruatlı bilgi için bk. Hersekli Ârif Hikmet: Külliyât-ı Âsâr 1: Dîvân [nşr. İbnülemîn Mahmud Kemâl], İstanbul 1334, s. 3-78; a.mlf., Son Asır Türk Şâirleri, II, 639-642; M. Kayahan Özgül, Hersekli Ârif Hikmet, Ankara 1987, s. 1-59.)

Ârif Hikmet Bey, Kemâleddin Efendi’nin başlıkta bahsettiği gazeli de Muallim Nâcîye nazîre olarak yazmıștır. İlk olarak Tercümân-ı Hakikat'de (nr. 13 Rebîülâhir 1300/ 21 Şubat 1883, nr. 1409, s. 3) yayımlanan söz konusu gazel şöyledir:

Nişân-ı aşka gönül erdi bî-nişân olalı Büyütdü sânını berhem-zidâ-yı şân olalı

Zihî garâmet-i sâmân ki oldu vasla sebeb Açıldı tâli'imiz sûdumuz ziyân olalı

Kapandı bahs-i esâtîr-i evvelîn-i cünûn Dilin hikâye-i sevdâsı dâsitân olalı

O mihr-i şa'şa'a-gîr-i sipihr-i hüsn ü bahâ Gözümden oldu avâlim nihân ayân olalı

Gelir mi hâtıra gül-geşt-i bâğ-1 heşt-behișt Gamınla dâğlarım reşk-i gülistân olalı

Safâ-pezîr-i rehâ var mı kayd-ı mihnetden Bu hâkdân-1 fenâ dâr-1 imtihân olalı

Fazîlet ehline her dem tahakküm-i cühelâ Cihânda kā'idedir tâ cihân cihân olalı Tezâyüd eyledi Hikmet sözünde feyz-i kemâl Cenâb-ı Nâcî-i üstâda hem-zebân olalı 
2. Buna mümâsil olan hâdisâtı sanmam ki Geçirmiş ola sicille cihân cihân olalı

3. Evet tebeddül ederdi hükûmet-i İslâm Taraf taraf hulefâ sevreti 'ayân olalı

4. Fakat hilâfeti hem de şerîati ilgâ Eden de var mı-dı hükkâm hükmrân olalı

5. Cinâyet 'addedilirmiş tilâvet-i Kur'ân Bir ülkede bu olur muydu müselmân olalı

6. Sezâdır etse teessüf cihân Kemâleddîn

Şu hâli görmedi zîrâ zamân zamân olalı

7. Bunun da hikmetini 'ârif olmayan bilmez

Cihân cemâl ü celâl nûruna mekân olalı ${ }^{81}$

\section{e) Musammatlar}

\section{4}

"Dünyâ denîdir gâye-i zikrullâh ganîdir." kelâm-ı hikmet-ittisâmı rüyâda bir zât tarafından telakkī edilip Hâcı Hazmî Efendi tarafından nazm edilmekle şu sûretle tahmîs ve ikmâl edilmişdir: ${ }^{82}$

Zamâne görmedi böyle yegâne mu'cize-gû

Kalem hakikkat-i i'câza tercümân olalı

(Ayrıca bk. Hersekli Ârif Hikmet: Külliyât-ı Âsâr 1: Dîvân [nşr. İbnülemîn Mahmud Kemâl], s. 248-249.)

Muallim Nâcînin Mes'̂ud Harâbâtî adıyla Tercümân-ı Hakỉkat’te neşrettiği

Çalıştı gerçi zebân kalbe tercemân olalı

Beyâna sı̆̆madı aşkın belâ-yı cân olalı

matla'lı gazeli Hersekli Ârif Bey’in yanısıra Ali Rûhî, Remzî-i Tebrîzî, Âișe Süreyya, Üsküdarlı Nedîm, Sıdkī, Așkīi Askerî ve Yahya Kemâl gibi şâirler tarafından tanzîr edilmiştir (Muallim Nâcînin şiiri için bk. Muallim Nâcî, Yazmış Bulundum, İstanbul 1301, s. 29-30; a.mlf., Muallim, İstanbul 1303, s. 10. Bu son eserde şiirleri kayıtll şâirlerden Ârif Hikmet Bey için bk. s. 143-144; Ali Rûhî, s. 11; Remzî-i Tebrîzî, s. 25-26; Âişe Süreyya, s. 62; Üsküdarlı Nedîm, s. 83-84; Sıdkī, s. 154, 220; Aşkī-i Askerî, s. 164. Yahya Kemâl'in gazeli için bk. Eski Şiirin Rüzgâriyle, İstanbul 1962, s. 37-38). Fevziye Abdullah Tansel, Türkiyat Mecmuasi'nda (X [İstanbul 1953]) neşrettiği "Muallim Nâci ile Recâizâde Ekrem Arasındaki Münâkaşalar ve Bu Münâkaşaların Sebep Olduğu Edebî Hâdiseler” adlı makalesinde Nâzım Paşa'nın Muhâtaba adlı eserinin 44. sayfasına atıfta bulunarak onun da Muallim Nâci’nin söz konusu gazelini tanzîr ettiğini söylemekteyse de ilgili eserde bu gazel veya bu gazelle ilgili bir ifâdeye rastlayamadık (Mehmed Nâzım Paşa [Florinalı Nâzım], Muhâtaba, I-II, Kostantiniyye 1316, Dersaâdet 1328).

81 Mecmûa, AÜİF Kütüphânesi, Yazmalar Blm., nr. 38182, vr. nr. yok.

$82 \mathrm{Hac}$ Hazmî Efendi hakkında bilgi için yk. bk. 63. dipnot. 


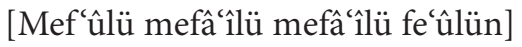

1. Bir zât ki irfân ile mümtâz ü senîdir

Her bir sözü makbûl sözün en hasenidir

Bak bak ne diyor sıhhati gâyet alenîdir

Dünyâ nazar-ı ehl-i hakikatde denîdir

Halkından anın gâye hemân zikr-i Ganî̀ir

2. İnsân ona derler ki olup sırrına mazhar

Dâim ola Hak zikri ile kalbi münevver

Dünyâyı göre geçmek içün bir kuru ma‘ber

Kâmildir o kim kasdı Hak olmakla berâber

Münkādı reh-i şer' $i$ Resûl-i Medenîdir ${ }^{83}$

35

Kemâleddin Efendi’nin Gelibolulu Âlî̀nin aşağıdaki beytinden sonra “Tarz-1 âcizîden 'ilâve edilen de şudur” diyerek yazdığg beyit: ${ }^{84}$

[Mefâ‘îlün mefầîlün mefầîlün mefầîllün]

Habîbin sev takarrubsa murâdın Hakk'a ey Âlî

Rakīb olmak gibi Allah'a rengîn intisâb olmaz

Şu sûretle rakībin Hak olunca korkma dûzahdan

Cinân-1 vuslata bundan güzel râh-1 savâb olmaz ${ }^{85}$

83 Mecmûa, AÜİF Kütüphânesi, Yazmalar Blm., nr. 38182, vr. nr. yok. Hazmînin kıt'ası için ayrıca bk. Hayrettin Ayaz, Harputlu Abdülhamîd Hazmî: Dîvân, s. 119.

84 Gelibolulu Mustafa Âlî (v. 1008/1600) çok sayıda manzum-mensur eser vermiş bir Osmanlı müellifidir. Bilhassa Künhü'l-ahbâr’’ en önemli eseri sayılmaktadır. Hayatı, eserleri, karakteri, edebî yönü hakkında kıymetli bilgiler için bk. Bekir Kütükoğlu-Ömer Faruk Akün, "Âlî Mustafa Efendi”, DİA, İstanbul 1989, II, 414-421.

85 Mecmûa, AÜİF Kütüphânesi, Yazmalar Blm., nr. 36, s. 150. Gelibolulu Âlîye âit olan ilk beyit için bk. Bursalı Mehmed Tâhir, Osmanlı Müellifleri, III, 86; İsmail Hakkı Aksoyak, Gelibolulu Mustafa Âlînin Divanları, Harvard University 2006, II, 110. 
$\underline{36}$

\section{Emîn Paşazâde Kemâl Beg'in ${ }^{86}$ Bir Gazeline Mutarref Tahmîsdir:}

[Mef'îlü mefầîlü mefâ‘̂̂lü fe'ûlün]

1. Âlemleri tenvîr eder envâr-ı kemâlin

Şâma eremez şu'le-i eshâr-1 kemâlin

Şevk-âver olur gönlüme dîdâr-1 kemâlin

Mümkün olamaz âleme 1zhâr-1 kemâlin

Her zerrede meșhûd olur âsâr-ı kemâlin

2. İdrâk edemez künhünü erbâb-ı 'ukûl âh

Yok dâire-i vasfına ebvâb-ı duhûl âh

Tercîhde âciz kalır ashâb-ı kabûl âh

Dembeste-i hayret olur elbâb-1 fuhûl âh

'Âkılleri mecnûn eder esrâr-ı kemâlin

3. Dûçâr-ı zevâl olmada her mihr-i fürûzân

Âfâkın olur mâhı dahi mâil-i noksân

Dikkat ile 'atf eylese enzârını insân

Evsâf-1 kemâli göremez kimseye şâyân

Käbil mi 'aceb kâmile inkâr-ı kemâlin

4. Pür zemzeme her şâm ü seher gülşen-i âfâk

Takdîr ediyor 'aczi ile elken-i âfâk

Tahrîr ediyor hâme-i tarh efgen-i âfâk

Âvâz ile tolmuş yine pîrâmen-i âfâk

Tekbîr ediyor şânını ezhâr-ı kemâlin

$86 \mathrm{Bu}$ zât İbnülemîn Mahmud Kemâl İnal'dır (v. 1376/ 1957). İbnülemîn'in Efendigil âilesiyle irtibâtı çocukluğunu yanında geçirdiği akrabası ve çok hürmet duyduğu büyüğü Arapgirli Sadrazam Yusuf Kâmil Paşa’nın (v. 1293/1876) Kemâleddin Efendi’nin babası Abdülhamîd Hamdî Efendi'ye gösterdiği yakın alâka sebebiyledir. Bu alâkaya İbnülemîn de kayıtsız kalmamış, hem Abdülhamîd Hamdî Efendi hem de oğlu Kemâleddin Efendi ile dostluk kurmuş, Yusuf Kâmil Paşa ile beraber o sıralar Harput’a bağlı bir kazâ olan Arapgir’i ziyâretlerinde Harput'a da uğramışlar ve Efendigil âilesini ziyâret etmişlerdir. İbnülemîn Efendi’nin hem Abdülhamîd Efendi hem de Kemâleddin Efendi ile dostlukları ömür boyu devam etmiştir. (Daha geniş bilgi için bk. İbnülemîn, Sona Asır Türk Şâirleri, I, 533-534; Ahmet Karataş, "Harput Ulemâsından Müderris-Müftü Mehmed Kemâleddin Efendi”, s. 32. İbnülemîn’in hayatına dair teferuatlı bilgiler için bk. Hüseyin Vassâf, Kemâlül-Kemâl: Bir Eski Zamân Efendisi İbnülemîn Mahmud Kemâl [haz. Fatih M. Şeker-İsmail Kara], İstanbul 2009; Ömer Faruk Akün, "İbnülemîn Mahmud Kemâl”, DİA, İstanbul 2000, XXI, 249-262.) 
5. Ta'tîr-i meşâm etmede 'uşşâk-ı hakik

Tebcîl olunur şükr ile Hallâk-1 hakīkat

Hakkā ki safâ sürmede müştâk-ı hakīkat

Hoş-bû ile pürdür bugün âfâk-1 hakỉkat

Feyz-âver olur nefha-i gülzâr-ı Kemâl in ${ }^{87}$

37

\title{
Hazmî Efendi’nin Bir Kıt'asını Tahmîs
}

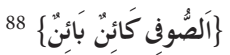

[Fe`ilâtün fe'ilâtün fe‘ilâtün fe‘ilün]

Gerçi zâhirde habersiz gibi bâindirler

Fakat Allâh ile her hâlde kâindirler

Mâsivâ hubbına bi'l-cümle mübâyindirler

Sâminî erleri her maksadı zâmindirler ${ }^{89}$
Tekye-i 'aşka gelüp sıdk ile Allâh diyene

Hakk'a rabt eyle hemân rişte-i fikr ü 'azmi

Koma nâbûd ola silkindeki zann ü cezmi

Ara bulmak içün âfâk ile sadr-1 bezmi

\author{
Yed-i imdâd ü 'inâyet uzadırlar Hazmî ${ }^{90}$ \\ Âteş-i derd-i İlâhîye düşüp âh diyene ${ }^{91}$
}

87 Mehmed Kemâleddin Harputî. Hazîne-i Fünûn, III/17 (28 Rebîülâhir 1313/ 18 Ekim 1895), s. 138-139.

88 İmam Rabbânîye atfedilen bu söz Nakşîliğin esaslarından sayılmakta olup kişinin bedenen halkla, kalben Hak'la olması gerektiğini anlatır. (bk. İmam Rabbânî, ed-Dürerül-meknûnâti’n-nefîse, İstanbul 2002, s. 55.)

89 [Kemâleddin Efendi:] Eâzım-1 meşâyıh-ı Nakşibendiyye-i Hâlidiyye’den Paluvî Hâce Mahmûd Sâminî Hazretleri'dir.

Baskıda sehven "Nâminî” olarak çıkan "Sâminî” XIX. asrın önde gelen Nakşî-Hâlidî meşâyıhından olup Kemâleddin Efendi’nin şeyhi İmam Efendỉnin mürşididir. Doğum târihi belli olmayan Mahmud Sâminî Hazretleri Ma 'mûretü'l-azîz (Elazığ)'in Palu ilçesinde doğmuş, Mevlânâ Halid Bağdadînnin (v. 1242/1827) halifelerinden olan Ali Septî Efendi'den (v. 1287/1870) icâzet almış 1315/1898'de Palu'da vefât etmiştir. Sâminî Efendi şeyhi Ali Sebtî Efendi ile beraber Hâlidîliğin bölgede yayılmasına öncülük eden zevâttandır. (Hayatı ve menâkıbı hakkında bk. Abdulkadir Kıyak, Elazı̆̆ ve Yöresinde Ziyaret Fenomeni Üzerine Bir Din Bilimi Araştırması, [doktora tezi, 2010], Erciyes Üniversitesi Sosyal Bilimler Enstitüsü, s. 238-240.)

90 [Kemâleddin Efendi:] Ma'mûretü'l-'azîz vilâyeti Nâfía kâtibi 'Abdülhamîd Hazmî Efendi.

91 Cerîde-i Sûfiyye, nr. 24/10 (10 Zilhicce 1330/ 20 Kasım 1912), s. 8. Hazmînin kıt'ası için ayrıca bk. Hayrettin Ayaz, Harputlu Abdülhamîd Hazmî: Dîvân, s. 283. Bu neşirde üçüncü mısrâdaki "uzadırlar" kelimesi "üzredirler" şeklindedir. 
38

\section{Emîn Paşazâde Kemâl Beg’in Na't-i Şerîfine Mutarref Tahmîsdir:}

[Fâ'ilâtün fâ‘ilâtün fâ‘ilâtün fâ‘ilün]

1. Hâdisât-ı dehre dâim hasr eden efkârını

'Âlemin seyr eyleyen bî-sûd olan bâzârını

İnkılâb-1 çerh-i dûna 'atf eden enzârını

Tünd-bâdıyla zamânın bozmayan etvârını

Kâinâtın keşf eder hîç şüphe yok esrârını

2. Şân-ı 'âlü'l-âlini her lahza tekbîr eylerim

Âyet-i sun'in görüp hürmetle tefsîr eylerim

Çeşm-i 'ibretle bakıp tekrîm ü tevfîr eylerim

Hâl ü kāl-i 'acz ile tahsîn ü tevkīr eylerim

Ben temâşâ eyledikçe sâni'in âsârmı

3. Eylemişken len terânî bangi Mûsầyı hamûşs ${ }^{92}$

Etdi 'akl u fikrimi âzâde-i idrâk ü hûş

Feyz-i 'aşkın gönlüme bahş eyledi cûş u hurûş

Kat'-1 ümmîd eylemez ayrılmaz ammâ çeşm ü gûş

Dil yine eyler temennî rüyet-i dîdârını

4. Ahmedîyim tâlib-i dîdârı olsam çok mudur

'Âşık u dildâde-i reftârı olsam çok mudur

Bendesiyim mahrem-i esrârı olsam çok mudur

Cân u dilden mâil-i ruhsârı olsam çok mudur

Dîde-i hakbîn ki dâim seyr eder envârını

92 len terânî: "Beni göremezsin!” (Hz. Mûsânın Tûr’da Cenâb-1 Hakk’a "Rabbim, bana görün, sana bakayım!" diye yalvarması üzerine Allah Teâlầnın verdiği cevap.) el-A'râf 7/143. 
5. Bir ilâhî nağmedir gûş eyleyen bîdâr olur

Feyz-i te'sîriyle insân vâkıf-ı esrâr olur

Ger işitse Kays-1 Mecnûn âkil ü hüşyâr olur

Anlayanlar vecd alır her hâli 'ibretdâr olur

Şâ'ir-i vahdet-şinâsın şi'r-i hikmet-bârını ${ }^{93}$

\section{f) Kit'alar}

39

$\left[\mathrm{Na}^{\mathrm{s}} \mathrm{t}\right]$

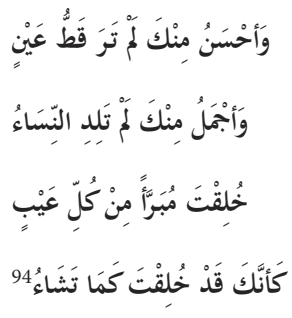

[Mefầîlün mefâ‘̂̀lün fe ûlün]

Eyâ fahr-i rusül senden güzel zât

Ne göz görmüş ne toğmuş kimse heyhât

Murâdın üzre sanki halk olundun

Bir 'aybın olmadığı $[n]$ eyler isbât ${ }^{95}$

93 Kemâleddin Harputî. Hazîne-i Fünûn, III/19 (12 Cemâziyelevvel 1313/ 31 Ekim 1895), s. 151.

94 Bu kıt'a şâir sahâbîlerden Hassân b. Sâbit'e âittir. bk. Dîvânu Hassân b. Sâbit (haz. Abdülemîr Ali Mühennâ), Beyrut 1994, s. 21. Kıt'a Üsküdarlı Zakirbaşı Ali Efendi tarafından rast makamında bestelenerek tekkelerde okunmuş, bazı hattatlar tarafından ise hutût-ı mütenevvia ile yazılarak çeşitli mekânların duvarlarını süslemiştir.

95 Kemâleddin Harputî. Cerîde-i Sûfiyye nr. 24/18 (4 Rebîülâhir 1331/ 13 Mart 1913), s. 8. 
$\underline{40}$

\section{İstanbullu Mir'âtzâde Şevkī Beyefendi'nin Âyîne-i Hakìkat adındaki eserine karşı tasvîr ve tahrîr etdiğim vecîz bir takdîrnâme-i 'abd-i âcizdir: ${ }^{96}$}

[Mef' ûlü fâ'ilâtün mef' ûlü fâ'ilâtün]

Bak gösterir edersen 'atf-1 nigâh-1 dikkat

Hakkıyla hakkı yâ hû Âyîne-i Hakỉkat

Meşkûr ola İlâhî Şevkī Bey’in bu sa'yi

Mir'ât-ı hulkı zîrâ tenvîre etdi himmet

25 Teşrîn-i Evvel [1]927 ${ }^{97}$

$\underline{41}$

[Müstef'ilün fe'ûlün müstef'ilün fe'ûlün]
Allâh ise murâdın te'mîn edip huzûru
İhlâs ile be-her gün dergâh-1 Şeyh'e gel git
Gülzâr-1 Sâminîden bedrü'l-büdûr Bedrî
Mekşûf olur cihâna sa ${ }^{\text {y }}$ eyle sen de seyr et ${ }^{98}$

96 Mir'âtzâde Şevkī Bey ve eseri hakkında maalesef bilgi bulamadık.

97 Ma‘mûretü'l-‘azîz Vilâyeti Merkez Müftîsi Kemâleddin. Mecmûa, AÜİF Kütüphânesi, Yazmalar Blm., nr. 38182, vr. nr. yok.

98 Müftî-i Vilâyet Kemâleddin Harputî. Kemâleddin Efendi bu kıt’ayı şeyhi İmam Efendi’yi medih sadedinde yazmıştır. Üçüncü mısrâdaki Sâminî, İmam Efendi’nin şeyhi olan Mahmud Sâminîdir (hayatı ile ilgili yk. bk. 89. dipnot). Bedrî, İmam Efendi’nin mahlası; Gülzâr-ı Sâminî ise "Sâminînin gül bahçesi" mânâsı dışında İmam Efendi’nin tasavvufî sohbetlerinden oluşan kitabının adıdır.

Osman Bedreddin Efendi 1274/1857-1858'de Erzurum'da doğmuştur. 93 Harbi’ne (1293/ 1877-1878 Osmanl1-Rus Savaşı) tabur imamı olarak iştirâk ettiği için İmam Efendi diye meşhur olmuştur. 1343/ 1924'te Harput'ta vefât etmiş, tespit edilebilen şiirleri, sohbetleri ve mektupları Sohbetnâme, Gülzâr-ı Sâminî: Sohbetler ve Gülzâr-ı Sâminî: Mektûbât gibi adlarla bugünkü harflere aktarılarak neşredilmiştir. (Daha teferruatlı bilgi için bk. Osman Bedreddin Erzurumî, Gülzâr-ı Sâminî: Sohbetler, İstanbul 1993, I, 17-39; İshak Sunguroğlu, Harput Yollarında, II, 268-271; Günerkan Aydoğmuş, Harput Kültüründe Din Âlimleri, s. 129-149.)

(Kıt‘a için bk. Gülzâr-ı Sâminî: Mektûbât, İstanbul 2006, II, 690. ) 
$\underline{42}$

\section{Kemâleddin Efendi'nin Mahmûd Sâminî Efendi'nin Türbesi İçin Yazdı̆̆ı Kıt'a:}

[Mefâ‘îlün mefâ‘îlün mefâ‘îllün mefấîlün (fe‘ilün)]

Edin ta'zîm ile dâim ziyâret eyyühe'l-uşşâk

Cenâb-1 gavs-1 a'zam Sâminînin merkadidir

Teveffuk eylemişdir şübhesiz ekbere zâiri

Tarîk-i Nakşbendî mürşidinin erşedidir ${ }^{99}$

43

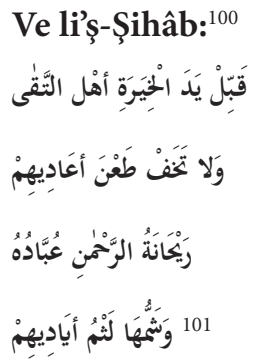

\section{Nazmen Tercümesi:}

[Fâ'ilâtün fâ'ilâtün fa'ilün]

\section{Ehl-i takvâ destini takbîl kıl}

Korkma reddet ta' $n$ ederse hasm-1 bed

'Ârif[ân] reyhâne-i Rahmân'dır

Anları şemm etmedir takbîl-i yed ${ }^{102}$

99 Üçüncü mısrâın sonundaki "zâiri" kelimesi metinde "zâidi" şeklindedir. Ancak bu okuyuş mısrâın mânâsına uymamaktadır. bk. Gülzâr-ı Sâminî: Mektûbât, II, 694.

100 Kemâleddin Efendi’nin kıt'asını nazmen tercüme ettiği "Şihâb”, Mısırlı müfessir, fakīh ve edîb Şihâbüddîn Ahmed b. Muhammed b. Ömer el-Hafâcî (v. 1069/1659)'dir. Hafâcînin ilim öğrenmek için seyahat ettiği șehirler arasında Mekke ve Medîne'den sonra İstanbul vardır. Burada Hoca Sadeddin Efendi, Ganîzâde Nâdirî, Azmizâde Hâlet gibi çok yönlü âlimlerden istifâde etmiş ve hüsn-i kabul görerek önce Rumeli kadılı̆̆ına bilâhere de Üsküp ve Selânik kadılıklarına atanmıştır. En son kazasker olarak Mısır'da vazîfe yapan Hafâcî çeşitli dedikodular sebebiyle azledilince ömrünü eser yazmakla geçirmiştir. Tabakāt, edebiyat, dil, tefsir sâhasında yazdığı eserler şöhret bulmuş, bunların birçoğu basılmıştır. Ulemânın yakın alâkasına mazhar olması bakımından 'İnâyetül-Kādî ve kifâyetürr-Râzî 'alâ Tefsîri’l-Beyzâvî adlı Envârü't-tenzîl (Beyzâvî) hâşiyesi ile Nesîmü’r-riyâz fî şerhi Şifâi’l-Kādî ‘Iyâz adlı hacimli eseri diğerlerine nazaran daha revâç bulmuştur. (Daha geniş bilgi için bk. Ali Şâkir Ergin, "Hafâcî", DİA, İstanbul 1997, XV, 72-73.)

101 Kit'a için bk. el-Hafâcî, Dîvân, yy., ty., s. 159; a.mlf., 'Inâyetü'l-Kādî ve kifâyetü’r-Râzî 'alâ Tefsîri'l-Beyzâvî (HâşiyetüşŞihâb 'alâ Tefsîri'l-Beyzâvî), Kahire 1283, s. 6 (ek kısım).

102 Kemâleddin Harputî. Cerîde-i Sûfiyye nr. 24/7 (18 Şevvâl 1330/ 30 Eylül 1912), s. 7. 


\section{$4 \underline{4}$}

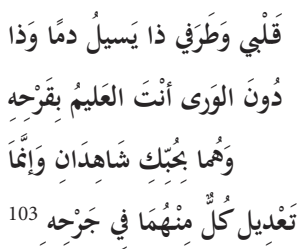

[Fe'ilâtün fe'ilâtün fe'ilâtün fe'ilün]

Dil-i hûn-pâş ile şu dîdelerim gerçi benim

Sıdkıma da'vî-yi mihrinde iki şâhiddir

Bu 'acebdir ki o şâhidlerim[in] ta'dîli

'Alenen zâhir olan cerhlerine âiddir 104

45

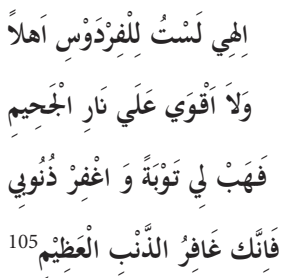

[Fe'ilâtün (fâ‘ilâtün) fe'ilâtün fa'lün]

Değilim lâyık-ı cennet yâ Rab

Dûzaha karşı da 'aczim zâhir

Tevbe etdir de beni 'afv eyle

Sensin 'isyân-1 'azîmi ğâfir ${ }^{106}$

103 Bu misrâlar Mecdüddin Ebû Abdillâh b. ez-Zahîr el-İrbilî el-Hanefî̀ye (v. 677/1278) âittir. Fakīh, edîb, dil ve nahiv âlimi olan bu zât Şam'da devrinin meşhur ulemâsından eğitim almış, Mısır, Erbil ve Bağdat’ta müderrislik yapmış, çok sayıda talebe yetiştirmiştir. Kaynaklarda onun fazîletli, dürüst, güvenilir bir zât olduğu vurgulanmıştır. Eserleri arasında en meşhuru Dîvân'ıdır. (bk. Şemseddin Ebû Abdillâh Muhammed b. Ahmed b. Osmân ezZehebî, Târîhu'l-İslâm ve vefeyâti'l-meşâhîri ve'l-a'lâm [thk. Beşşâr Avvâd Ma'rûf], Beyrut 2003, XV, 345; Celâleddin Süyûtî, Kitâbü Buğyetill-vu'ât fî tabakäti'l-lügaviyyîn ve’n-nuhât [thk. Muhammed Ebü’l-fazl İbrâhîm], Lübnan 1979, I, 37; Salâhaddin Halîl b. Aybek es-Safedî, Kitâbü'l-vâfî bi'l-vefeyât, Beyrut 2000, II, 87-88; Dîvânu İbni'zZahîr el-İrbilî, yy. ty., s. 38; İbn Hicce el-Hamevî, Hizânetü'l-edeb ve gâyetü'l-ereb, Kahire 1291, s. 265; Selâhaddin Muhammed b. Şakir el-Kütübî ed-Dârânî, Fevâtül-vefeyât, yy., 1282, II, 220.)

104 Kemâl. Mecmûa, AÜİF Kütüphânesi, Yazmalar Blm., nr. 38182, vr. nr. yok.

105 Kit‘a, Abbâsî döneminin meşhûr şâirlerinden Ebû Nüvâs (v. 198/814)'a atfedilmekteyse de Ebû Nüvâs'in dîvânının incelediğimiz neşirlerinde buna rastlayamadık (Dîvânü Ebî Nüvâs, Kâhire 1898; a.g.e., Beyrut ty.). Kemâleddin Efendi’nin mecmûasında manzum tercüme ile birlikte kıt'anın aslı da yer almaktadır.

106 Li-nâzımihî Kemâleddin el-Harputî el-Müftî 'ufiye 'anh. Mütenevvi' Duâ ve Nüshalar Mecmûası, AÜİF Kütüphânesi, Yazmalar Blm., nr. 89, vr. nr. yok. 
$\underline{46}$

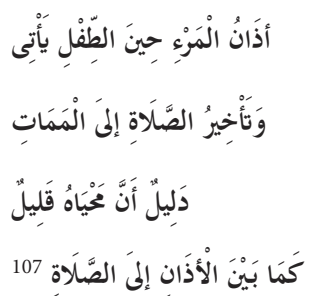

[Mefâ‘ilün fe'ilâtün mefâ‘ilün fe'ilün]

Velâdetinde ezânı okunması kişinin

Namâzı hâl-i memâtına olması te'hîr

Hayâtının bir ezânla namâz beyni kadar

Kalîl olmasına oldu bir delîl-i kebîr ${ }^{108}$

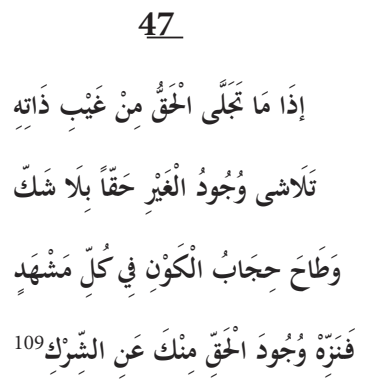

107 Bu kıt'a bazı eserlerde Ebu'l-Atâhiyye (v. 213/826)'ye atfen, çeşitli müntehablarda ise müellifi belirtilmeksizin

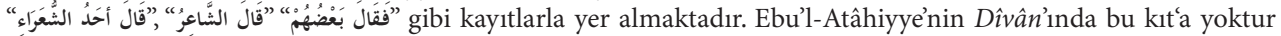
(b́k. Dîvânu Ebül-Atâhiyye, Beyrut 1886; Ebü'l-Atâhiyye eşâruhu ve ahbâruhu [thk. Şükrî Faysal], Kahire 1965). Kit'a için bk. Sâlih b. Mukbil el-Asîmî et-Temîmî, el-Vicâze fî istismâri'l-vakti ve’l-icâze, Riyad, ty, s. 26). Cerîde-i

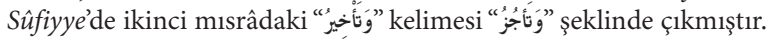

108 Kemâleddin Harputî. Cerîde-i Sûfiyye nr. 24/13 (23 Muharrem 1331/ 2 Ocak 1913), s. 9.

109 Kit‘a Muhammed Ebü'l-Mevâhib el-Mâlikî eş-Şâzelî el-Vefâî (v. 882/1477)'ye nisbet edilmiştir. Nisbelerinden de anlaşılacağ1 üzere sûfî bir âlim olan bu zât 820/1417'de Tunus'ta doğmuş, iyi bir eğitim görerek zahirî ve bâtınî ilimlerde mertebe katetmiş, Kahire'de Câmi'atü'l-Ezher'e yakın bir yerde bulunan tekkesinde yüzlerce mürîd yetiştirmiş ve burada vefât etmiştir. İbn Zuğdân olarak da bilinen ve "kenzü'l-ârifîn, alemü'z-zâhidîn” diye tavsîf edilen Ebü'l-Mevâhib'in tabakāt kitaplarında ahlâkı, seciyesi, fazîleti, sohbetleri, tesiri ile ilgili rivâyetler ve menâkıb anlatılmaktadır. Ebü'l-Mevâhib'in bir çok eseri arasında özellikle el-Ezkiyâ fî ahbâri'levliyâ, Mevâhibü'l-ma'ârif, Bugyetü's-suâl an merâtibi ehli'l-kemâl, Kavânînu hikemi'l-işrâk ilâ sûfiyyeti cemî'i'lâfâk çok rağbet görmüştür. (Hayatı hakkında daha teferruatlı bilgiler için bk. Abdülvehhâb eş-Şa'rânî, etTabakātül-kübrâ [thk. Ahmed Abdurrahîm es-Sâyih-Tevfîk Ali Vehbe], Kahire 2005, II, 135-162; İbnü’l-İmâd, Şezerâtü'z-zeheb fî ahbâri men zeheb [thk. Abdülkādir el-Arnaut-Mahmûd el-Arnaut], Beyrut 1993, IX, 502503; Ömer Rızâ Kehhâle, Mu'cemü’l-müellifîn, Beyrut 1993, III, 100. Kıt'a için bk. Şa'rânî, et-Tabakātül-kübrâ, II, 142.) 


\section{Nazmen Tercümesi:}

[Fe'ilâtün (fâ‘ilâtün) fe'ilâtün fe'ilâtün fe‘ilün (fa'lün)]

Gayb-1 zâtından eğer etse tecellî Settâr

Mütelâşî olur elbette vücûd-1 ağyâr

Cümle meşhedde düşer idi hicâb-1 kevni

Hakk’ı tenzîh ede gör şirk ile senden her bâr ${ }^{110}$

$\underline{48}$

[Mefâ‘îlün mefâ‘îlün fe ûlün]

Bu dünyâ çok yaşamış bir kocadır

Benim babam hoca oğlu hocadır

Nasîhatler ki kâr etmez oldu

$\mathrm{Bu}$ gidişin aceb sonu nicedir ${ }^{111}$

49

\section{Türbe-i Hazret-i Mevlânâ'yı ziyâret etdiğim vakitde yazılmışdı:}

[Fe'ilâtün (fâ‘ilâtün) fe'ilâtün fe'ilün (fa'lün)]

Dergeh-i Hazret-i Mevlânâya

Yüz sürenlere karışdım saf saf

Beni de bendeliğe etse kabûl

Tâ ebed müftehir eyler ne şeref ${ }^{112}$

$\underline{50}$

[Fe'ilâtün (fâ‘ilâtün) fe'ilâtün fe'ilâtün fe'ilün (fa'lün)]

Gark-1 nûr etdi gelip şehrimizi mâh-1 sıyâm

Geliniz söyletelim biz dahi parlak parlak

Ramazânda yürümez kāiide-i şürb-i müdâm

Bâri çay nûş edelim şevk ile bardak bardak ${ }^{113}$

110 Kemâleddin Harputî. Cerîde-i Sûfiyye nr. 54 (17 Şa‘bân 1331/ 22 Temmuz 1913), s. 72.

111 Mecmûa, AÜİF Kütüphânesi, Yazmalar Blm., nr. 37019-20, arka kapak zahriyesi.

112 Müftî Kemâleddin. Mecmûa, Ankara Üniversitesi Kütüphânesi Yazmaları, nr. 38182, vr. nr. yok.

113 Mecmûa, AÜİF Kütüphânesi, Yazmalar Blm., nr. 36, s. 151. 
$\underline{51}$

[Fe'ilâtün fe'ilâtün fe'ilün]

Sûfiyâne yazılan bu eserim

Görünür gerçi birazca muğlak

Fakat imân-1 nazar eylemeli

Anlaşılmaz da değildir mutlak ${ }^{114}$

$\underline{52}$

يَا سَبِّدي إنْ جَرى مِنْ مَدْمَعِي وَدَدمِي

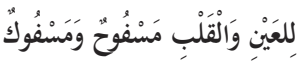

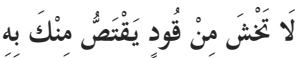

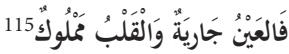

[Fe'ilâtün (fấilâtün) fecilâtün fe'ilâtün fe'ilün (fa'lün)]

Dil-i gamgîn ile dîdemden eğer mevlânâ

Yaş akıp hûn-1 hazîn olsa da her dem mesfûk

Havfnâk olma tasasından anın çünki sana

Dîdemiz câriyedir kalbimiz 'abd-i memlûk ${ }^{116}$

114 Kemâleddin Efendi’nin Kasîde-i Münferice’nin Tahmîsiyle Berâber Türkçe Şerhidir adlı eserinin dış kapağına kaydettiği kıt'asıdır.

115 Arapça kıt‘a İbnü'l-Mürahhil, İbnül-Vekîl, İbnü’l-Hatîp gibi ünvânlarla bilinen Şâfiî fakīhi Sadreddin b. el-Vekîle (v. 716/1317) aittir. Dimyât’ta (Mısır) doğan, Şâm’da devrin en meşhur hocalarından dersler alarak yetişen İbnü'lVekîl büyük bir âlim ve adından söz ettiren bir edîbtir. Şam’da ve Kahire’de müderrislik, Dârülhadîs meşîhatlı̆̆ 1 gibi vazifelerde bulunmuş, o dönemde İbn Teymiyye ile revâç bulan Selefî düşünceye karşı Eş'arî aki்de anlayışını savunarak hem ulemânın hem de halkın takdirine mazhar olmuştur. Şâfiî fikhı ve usûlü yanısıra hadîs, kelâm, felsefe ve tıpta da iyi bir birikime sahip olduğu rivâyet edilen müellifin eserleri arasında el-Eşbâh ve’n-nezâir, Şerhu'l-Ahkâm, Trrâzü'd-dâr bulunmaktadır. Hayatı hakkında daha teferruatlı bilgi için bk. Bilal Aybakan, "İbnü’lVekîl”, DİA, İstanbul 2000, XXI, 237-238. Kit'a için bk. İbn Hicce el-Hamevî, Hizânetü'l-edeb ve gâyetü’l-ereb, s. 314; Bahâüddîn Muhammed b. Hüseyn b. Abdissamed el-Âmilî, el-Keşkûl (thk. Muhammed Abdülkerim en-Nemrî), Beyrut 1998, I, 82.

116 Kemâl. Mecmûa, AÜİF Kütüphânesi, Yazmalar Blm., nr. 38182, vr. nr. yok. 
$5 \underline{3}$

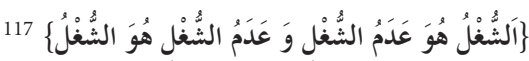

[Mef' ûlü mefầîlü mefầîlü fe'ûlün]

Şuğlün ‘ademi şuğl imiş ey sâlik-i makbûl

Fâriğler olur ya'nî Hudâ’sı ile meşgûl

Şuğlü 'adem ile 'ademi şuğl ile tefsîr

Eslâfdan olmuş bize îhâm ile menkūl ${ }^{118}$

$5 \underline{4}$

\section{Bir Manzûme-i 'Arabiyye ve Tercümesi}

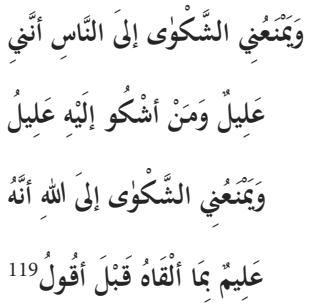

[Fe'ilâtün (fầilâtün) fe'ilâtün fe'ilâtün fe‘ilün (fa'lün)]

Halk-1 âlem de benim gibi bütün âcizdir
Sözüme söylemeden 'ilm-i İlâhî şâmil
İşte nice şu iki hâl-i kavî hâcizdir
Halk ile Hâlık'a şekvâ edemem el-hâsıl ${ }^{120}$

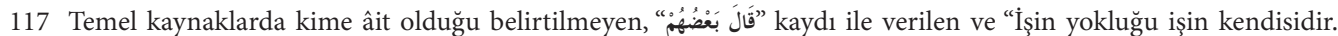
İşizlik başlı başına bir iştir.” mânâsına gelen bir kelâm-ı kibâr. bk. Muhammed b. Muhammed Ahmed elBüdeyrî ed-Dimyâtî, el-Cevâhirü'l-ğavâlî fî zikril-esânîdi'l'avâlî (yazma nüsha), s. 190, http://books.islam-db.com/

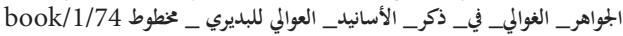

118 Üçüncü mısrâdaki “ademi” kelimesi metinde sehven “"ademin” şeklinde çıkmıştır.

Kemâleddin Harputî. Cerîde-i Sûfiyye nr. 24/11 (25 Zilhicce 1330/ 5 Aralık 1912), s. 8

119 Bu kıt’a Sühreverdiyye tarîkatının kurucusu Ebû Hafs Şihâbüddin Ömer Sühreverdî (v. 632/1234)’ye atfedilmektedir. Birçok âlim ve sûfînin yetiştiği bir âilenin ferdi olan Sühreverdî İran sınırlarında doğmuş, Bağdat Nizâmiye Medresesi’nde okumuş ve orada müderrislik yapmıştır. Abdülkādir Geylânî, Evhadüddîn Kirmânî, Ahmed el-Gazzâlî ve Muhyiddin İbn Arabî̀den tefeyyüz etmiş, Malatya’da Necmeddin Dâye, Konya’da Bahâeddin Veled, Mekke'de İbn Fârız'la görüşmüştür. Yaşadığı dönemde “şeyhu’ş-şüyûh" olarak anılan Sühreverdî tekkedeki sohbet ve irşâdının yanısıra fıkıh, hadis, kelâm da okutmuş, birçok mühim talebe yetiştirmiştir. Avârifü'l-ma ârif, Nuğbetü̉l-beyân fî tefsîri'l-Kur'ân, İş̧âdü'l-mürîdîn gibi yirmiye yakın eseri asırlarca ilim erbâbı ve sûfîler tarafından okunmuştur. Hayatı, tarîkatı ve tesirleriyle ilgili bk. Hasan Kâmil Yılmaz, "Sühreverdî”, DİA, İstanbul 2010, XXXVIII, 40-42; Reşat Öngören, "Sühreverdiyye”, DİA, İstanbul 2010, XXXVIII, 42-45. Kit'a için bk. Şihâbüddin Seyyid Mahmûd el-Alûsî, Rûhu'l-me ânî fî tefsîri'l-Kur'âni'l-'azîm ve’s-seb'u'l-mesânî, Beyrut ty., XIII, 241; Ebû Bekr Muhammed b. Velîd et-Turtûşî, Sirâcü̉l-mülûk, İskenderiyye 1289, s. 170.

120 Kemâleddin Harputî. Cerîde-i Sûfiyye nr. 24/13 (23 Muharrem 1331/ 2 Ocak 1913), s. 9. 


\title{
Hakîm-i ledünnî-mu'tâd edîb-i me'âlî-nihâd mesnevîhân-1 garâib-beyân 'Ali Fuâd Efendi'ye: ${ }^{121}$
}

\author{
[Fấilâtün fe 'ilâtün fe'ilâtün fe'ilün (fa'lün)] \\ Rû-nümâ olmuş iken vahdet ile zât-1 Hudâ \\ Şirk eden kimselerin çeşmi demek ki ahvel \\ Kalbini sakla tahavvülden amân eyle recâ \\ Bizden ayırmaya tevhîdini Hakk 'azze ve cell ${ }^{122}$
}

$5 \underline{56}$

[Fe'ûlün fe ûlün fe ûlün fe ûl]

İlâhî duâmı kabûl et benim

Mahall-i füyûz eyle cân u tenim

Bu cân bülbülü çün kafesden uça

Riyâz-1 cinân içre kıl meskenim ${ }^{123}$

121 Bu kıt'a önce Hazîne-i Fünûn'da sonra Cerîde-i Sûfiyye'de neşredilmiştir. Kıt'a Hazîne-i Fünûn neşrinde ithâfsızdır.

Mesnevîhân Ali Fuâd Efendi Cerîde-i Sûfiyye’nin başyazarıdır. Gerek Cerîde-i Sûfiyye gerekse dönemin matbuâtı ile ilgili birçok çalışma bulunmasına rağmen araştırmacılar Ali Fuâd Efendi hakkında herhangi bir bilgiye rastlamadıklarını söylemektedirler. Bu sebeple yapılan çalışmalar daha çok onun Cerîde-i Sûfiyye'deki yazılarının bugünkü harflere aktarılması ve yorumlanmasından ibâret kalmıştır. (Birkaç örnek için bk. Gabriele Karayel, The First Six Editions of Ceride-i Sufiyye (19th March, 1909-2nd May, 1909) or Sufism as a Metaphor, yüksek lisans tezi, 1990, Boğaziçi Üniversitesi SBE; Atilla Kaşıkçı, Bütün Yönleriyle Cerîde-i Sûfiyye, yüksek lisans tezi, 1994, Dicle Üniversitesi SBE; Abdurrahman Acer, Mesnevîhân Ali Fuâd Efendinin Cerîde-i Sûfiyye'deki Makaleleri, yüksek lisans tezi, 2011, Marmara Üniversitesi SBE.)

Ali Fuâd Efendi Kemâleddin Efendi’nin ithâf kıt'ası vesîlesiyle aynı sayfada şu notu yayımlamıştır: "Kemâleddin Efendi Hazretleri’nin muharrir-i hakīr hakkında eser-i teveccüh-i fezâil-perverâneleri olarak irsâl buyurmuş oldukları bâlâdaki nazmı 'aynen emirleri vechiyle gazetemize derc ettik. Hakkını iktisâba muvaffak olmayan ve kemâl-i 'acz ü meskenet içinde pûyân olan bir dervîş velev müşevvikāne olsa bile böyle teveccühlere nâ-lâyık olduğunu söylemekden hîçbir vakit geri turmaz.

Çün hacîlem ez sühan-i hâm-1 h ̂̀ş

Hem tü beyâmürz be-in'âm-1 h`îş

(Ali Fuâd Efendi’nin iktibâs ettiği beyit meşhur Fars şâiri Nizâmî-i Gencevîye âittir. [bk. Nizâmî, Mahzenü’-esrâr [haz. Hasan Vâhid Destgirdî], Tahran 1343, s. 11.])

122 Kemâleddin Harputî. Hazîne-i Fünûn, nr. IV/6 (22 Zilhicce 1313/ 4 Haziran 1896), s. 77; Cerîde-i Sûfiyye nr. 54 (17 Şa ‘bân 1331/ 22 Temmuz 1913), s. 72. Hazîne-i Fünûn neşrinde 3. mısrâdaki "Kalbini” kelimesi yerine "Fikrini” vardir.

123 Kemâleddin ufiye anh. Mütenevvi` Duâ ve Nüshalar Mecmûası, AÜİF Kütüphânesi, Yazmalar Blm., nr. 89 , s. 343. 
57

[Mef'ûlü fầilâtü mefầîlü fầilün]

Cân âleminde bir cevelân etmek isterim

Ben lâ mekânda tayy-1 mekân etmek isterim

Bîzâr u bî-huzûrum İlâhî zamâneden

Dergâh-1 izzetinde figân etmek isterim ${ }^{124}$

58

Bir fotoğraf üzere yazılmışdır:

[Mef'îlü mefầîlü mefâ‘̂̂lü fe ûlün]

Pîr olduğumu şüphesiz ey nâzır-1 sâfım

İsbât ediyor işte fotoğraf-ı tuhâfım

Bak sûret-i hâle n'ideyim oldu zarûrî

Âlâm u mihenden beni zannetme muâfım ${ }^{125}$

59

[Mef'îlü mefấilün fe ûlün]

Nâçîz eserim ki bu kitâbım

Kalsın sana yâdigâr benden

Oldukça musâdif-i nigâhın

Bir hâtıradır ümmîd senden

$1345[1926]^{126}$

124 Mecmûa, AÜİF Kütüphânesi, Yazmalar Blm., nr. 38182, vr. nr. yok. İshak Sunguroğlu’nda ilk iki mısrâ “Ben lâmekânda tayy-1 mekân etmek isterim/ Bülbül isem de kat'-1 zebân etmek isterim” şeklindedir (Harput Yollarında, II, 174).

125 Mecmûa, AÜİF Kütüphânesi, Yazmalar Blm., nr. 38182, vr. nr. yok.

126 Kemâleddin Efendi’nin Tesbîtül-mefhûm fî tahkikkit-tebe 'iyyeti beyne'l-'ilmi ve'l-ma'lûm isimli risâlesinin başına yazdığı kıt‘a. (bk. AÜDTCF Kütüphânesi, Mustafa Con Blm., nr. A/237, kapak sayfası.) 


\author{
Hamr-1 hakikiyi hak ile şerh edip \\ Âhir bu noktada oldu kitâb son \\ Yâ Rab inâyetinle Kemâl-i fakīre de \\ Aşk câmı ile Câmî gibi bir şarâb sun ${ }^{128}$
}

61

\title{
Ahmed er-Rifâ'î Hazretleri’nin bir kıt'ası:
}

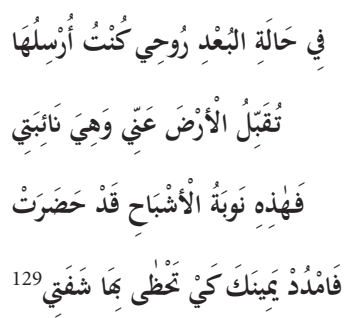

127 Kit'anın her bir mısrâında vezin farklılaşmakta, tef'ileler tutmamaktadır.

128 Ma'mûretü'l-azîz Vilâyeti Müftîsi Kemâleddin. Kemâleddin Efendi bu kıt'ayı Abdurrahmân Câmînin İbn Fârız’a ait 41 beyitlik Arapça Kasîde-i Hamriyye (Mîmiyye)'sinin manzum-mensur şerhi olan Farsça Levâmi inin tercümesini tamamladığında yazmıştır. Tercüme tefrikalar hâlinde Cerîde-i Sûfiyye’de neşredilmiştir. Kıt‘a için bk. Cerîde-i Sûfiyye, nr. 132 (27 Safer 1336), s. 330. Tefrikanın neşredildiği sayılar için bk. Ahmet Karataş, "Harput Ulemâsından Müderris-Müftü Mehmed Kemâleddin Efendi”, s. 86-88.

129 [Kemâleddin Efendi:] Ravza-i Mutahhara-i Nebeviyye’ye müsûl ettikde bu sûretle istirhâmda bulunmuş olan müşârünileyh hazretlerinin ârzûsu üzere nâil-i ecl-i emel olduğu da rivâyet-i sahîha ile sâbitdir.

Hz. Hüseyin'in soyundan gelen ve Rifâiyye tarîkatının kurucusu olan Ahmet er-Rifâî (v. 578/ 1182) Bağdat'a yakın bir bölgede doğmuş, babasının vefâtı sebebiyle devrin büyük sûfîlerinden olan dayısı Mansûr el-Batâihînin himâyesinde yetişmiş, çeşitli âlimlerden zâhirî ve bâtınî ilimleri öğrenmiş, icâzet aldıktan sonra şeyhu'ş-şüyûh olarak ömrü boyunca terbiye ve irşâd faaliyetlerini yürütmüştür. Kaynaklarda dört büyük kutubdan biri olduğu belirtilen (diğerleri Abdülkādir Geylânî, Ahmed Bedevî, İbrâhîm Desûkỉ veya Ebü’l-Hasan eş-Şâzelî) ve muhaddis, müfessir, Şâfiî fakīhi olarak zikredilen Ahmed er-Rifâînin tekkesini her gün binlerce kişinin ziyâret ettiği rivâyetler arasındadır. (Hayatı hakkında bilgi ve kaynaklar için bk. Mustafa Tahralı, "Ahmed er-Rifâ̂”", DIA, İstanbul 1989, II, 127-130.)

Kemâleddin Efendi’nin işâret ettiği Ravza-i Mutahhara ziyâreti ise şöyledir:

Rivâyete göre Ahmed er-Rifâîye Allah Teâlâ "Ahmed! Kalk da evimi ve peygamberimi ziyaret et!" diye ilhâm eder. Bunun üzerine Ahmed Rifâî bazı müridânı ile beraber önce Mekke’ye, sonra da Medine’ye ulaşır. Medine’de kalabalık bir cemaatle Hz. Peygamber’in kabrinin başına gelir ve "es-Selâmu aleyke yâ ceddî!" diye selam verir. Cevâp olarak kabr-i şerîfden "Ve aleyke's-selâm yâ veledî!” nidâsı işitilir. Nidâyı işiten Ahmed Rifâî Hazretleri vecde gelerek yukarıdaki kıt'ayı okur. "Elini uzat öpeyim ya Rasûlallah! Dudaklarım safâ bulsun!” mânâsına gelen son mısrâı söyledikten sonra kabir yarılır, Hz. Peygamber elini uzatır ve Ahmed Rifâî Peygamberimizin elini öper. Bu hâdiseye etrâftaki büyük kalabalık da şâhid olur. Bazı kaynaklara göre o kalabalık arasında Abdülkādir Geylânî, Adiyy b. Müsâfir, Hayât b. Kays el-Harrânî gibi zevât da bulunmaktadır. Kaynaklar bu hâdisenin tevâtür derecesine ulaştığını kaydederler.

(bk. Ebü’l-Hüdâ Muhammed b. Hasan Vâdî b. Ali Sayyâdî, Kllâdetü’l-cevâhir fî̀ zikri'l-gavsi’r-Rifâ'î ve etbâ'ihi’lekâbir, Beyrut 1301, s. 67-68; s. 21; Hasan Muhammed Şeddâd, el-Kevkebü's-sâ'î fî tercemeti ve sîreti seyyidî Ahmed er-Rifấ 'î, Beyrut 2013, 15-16; Muhammed Veysü'l-Hayderî, ed-Dürerü'l-behiyye fi'l-ensâbi'l-Hayderiyye ve'l-Üveysiyye, Halep 1405, s. 89-90.) 


\title{
Nazmen Tercümesi:
}

\section{[Mefầîlün mefâ‘îlün mefâ‘̂̂lün mefầîlün]}

Ba îd oldukda cismen rûhumu irsâl ederdim kim

Bana nâib olup dergâhın öpsün yâ Resûlallâh

Uzat dest-i şerîfin nevbet-i eşbâhdır bârî1 ${ }^{130}$

Lebim de hissemend-i devlet olsun yâ Resûlallâh ${ }^{131}$

\section{2}

\section{Celâleddîn-i Rûmî Hazretlerinin bir kıt'ası:}

\author{
Ger der-taleb-i lokma-i nânî nânî \\ V’er der-taleb-i cevher-i cânî cânî \\ În nükte zi-men bişnev eger mî-dânî \\ Her çîz ki der taleb-i ânî ânî ${ }^{132}$
}

Hüseyin Vassâf Efendi Gülzâr-ı Aşk'da yukarıdaki kıt'ayı da tercüme ederek bu mevzuu "Hazret-i Ahmed erRifâînin Yed-i Sa âdeti Takbîle Mazhariyyeti” başlığıyla anlatmaktadır. Kemâleddin Efendi’nin tercümesiyle karşılaştırma imkanı sağlamak için Vassâf Efendi’nin kıt'asını da buraya kaydedelim:

Nâibim olup zemîn hücreni takbîl için

Rûhumu irsâl ederdim hâl-i bưdîde şehâ

Hâzır oldu şimdi işbu devlete cismim dahi

Sun elin bûs edeyim cânâ lebim bulsun şifâ

(Hüseyin Vassâf, Gülzâr-ı Aşk [haz. Mustafa Tatcı ve dgr.], İstanbul 2006, s. 181. Tatcı neşrinde kıt'anın birinci mısrâındaki "hücreni" kelimesi "hacereni", ikinci mısrâındaki "bu'dîde" kelimesi "bu'diyedde"; dördüncü misrâındaki "bûs" da "pûş̧" şeklinde okunmuştur.)

Ahmed Rifâînin kıt'ası için ayrıca bk. el-Hafâcî, Tirâzu’l-Mecâlis, Kahire 1284, s. 146; Zafer Ahmed Sahib Tehânevî, el-Bünyânü'l-müşeyyed, Karaçi 1325, s. 25 (Eser Ahmed Rifâînin el-Burhânü'l-müeyyed'inin çeşitli notlarla zenginleştirilmiş Urduca tercümesidir. el-Burhânü'l-müeyyed’in aslında ise bu kıt'a bulunmamaktadır.); elÂlûsî, Ebü’l-ma'âlî Mahmûd Şükrî, Gâyetü'l-emânî fír-reddi 'ale’n-Nebhânî, Riyad 2001, I, 224. Bazı kaynaklarda

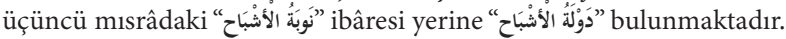

130 “Uzat” kelimesi gazétede “O zât” şeklinde yažılmıştır.

131 Kemâleddin Harputî. Bu kıt’a iki yazmada kayıtlıdır. bk. Mecmûa, AÜİF Kütüphânesi, Yazmalar Blm., nr. 25, vr. 99"; Mecmûa, AÜİF Kütüphânesi, Yazmalar Blm., nr. 38182, vr. nr. yok. Kıt'a ayrıca neşredilmiştir (Cerîde-i Sûfiyye nr. 24/21 [17 Cemâziyelevvel 1331/ 24 Nisan 1913], s. 5).

Kemâleddin Efendi Ahmed Rifâînin kıt'asının hem orijinalini hem de Türkçe manzum tercümesini neşrettiği bu sayıdan yaklaşık 3 ay sonra Cerîde-i Sûfiyye’nin 55. sayısında (24 Şa'bân 1331/ 29 Temmuz 1913, s. 84) Sa'deddin Sırrı Bey de kıt’anın Farsça manzum tercümesini yayımlamıştır. Hepsini bir arada görme imkânı sağlaması için bu manzum tercümeyi de buraya alıyoruz:

Hâk-i dergâhet be-bûsîden firistâdem dilem Yâ Resûlallâh be-hâl dûr büved nâib zi-men Hâzırest în dem ki cismem der huzûr-1 devletest Dest ber gîr lezzet-i bûsiş beyâbem derd hest

132 Rubâî B. Fürûzanfer neşrinde șu şekildedir: "Ger der-taleb-i menzil-i cânî cânî/ Ger der-taleb-i lokma-i nânî nânî/ În nükte-i remz eger be-dânî dânî/ Her çîz ki der cüsten-i ânî ânî” (Külliyât-ı Şems [haz. Bedîuzzamân Fürûzanfer], Tahran 1342, s. 313, rubâî nr. 1864.) 


\section{Nazmen Tercümesi:}

[Fâ'ilâtün fe'ilâtün fe'ilâtün fâ'lün]

Tâlib-i nân olu[yo]r nân ile Hak'dan mahcûb

Gevher-i rûh arayan ancak olur rûhânî

Her neye tâlib isen ana olursun mensûb

Dinle bu sırrı ki benden bulasın 'irfânı ${ }^{133}$

\section{3}

Men bende şodem bende şodem bende şodem

Men bende be-hıdmet ser-efgende şodem

Her bende ki âzâd şeved şâd büved

Men şâd ez ânem ki turâ bende şodem ${ }^{134}$

\section{Nazmen Tercümesi:}

[Fâ'ilâtün fầilâtün fấilün]

Rabbimin ben bendesiyim bendesi

Gerçi ‘isyânımlayım şermendesi

Bendeler âzâd olursa şâd olur

Ben de şâdım olduğumdan bendesi ${ }^{135}$

$$
\underline{64}^{136}
$$
$\mathrm{Al}$ da oku mütercem olan bu Levâmi i
'Afv et fakat cemîl-i hulk ile noksân-1 vâki'i
Lutf-1 'amîm-i Hudâ'dan ricâm odur
Mağfûr ola mütercimi hem de mutâli ‘ $i{ }^{137}$

133 Müderris Kemâleddin Harputî. Cerîde-i Sûfiyye, nr. 24/10 (10 Zilhicce 1330/ 20 Kasım 1912), s. 8.

134 Cerîde-i Sûfiyye'de şâiri zikredilmeyen bu rubâî Mevlânânındır. Ancak rubâî ne Fürûzanfer ne de Şefik Can (Hz. Mevlânânın Rubâileri, Ankara 2001) neşrinde bulunmaktadır. İsmâil Ankaravî Mesnevî şerhinde birkaç yerde bunu zikretmiştir. bk. İsmâil Rusûhî Ankaravî, Şerhu'l-Mesnevî, Bulak 1289, I, 12; III, 366. (Rubâînin üçüncü mısrâındaki "büved" kelimesi Ankaravîde her iki yerde de "şeved" şeklinde kayıtlıdır. İkinci mısrâdaki "behıdmet" kelimesi III. ciltte "be-hıdmetet" şeklindedir.)

135 Kemâleddin Harputî. Cerîde-i Sûfiyye nr. 24/11 (25 Zilhicce 1330/ 5 Aralık 1912), s. 8.

136 Kıt’anın vezni bozuktur. Üçüncü mısrâda muhtemelen bir kelime noksandır.

137 Ma'mûretü'l-azîz Vilâyeti Müftîsi Kemâleddin. Kemâleddin Efendi bu kıt'ayı Abdurrahmân Câmînin Levâmi‘ tercümesini tamamlaması hasebiyle yazmıștır. Nitekim kıt‘nın altında da tefrikalar hâlinde neşredilen bu tercü- 
Kit'a-i Kebîreler:

$\underline{65}$

\section{Kemâleddin Efendi’nin ferâizle ilgili bir lugazi nazmen çözmesi:}

\section{Lugaz:}

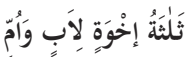

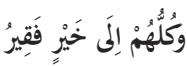

أَفَاَتْهُمْ صُروفُ الدَّهْر إرْتًُا

[2]

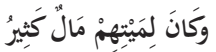

فَحَازَ الْالْكَبْرَانِ هُنَاكَ ثُلُثُا

[3]

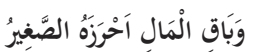

\section{Lugazin Halli:}

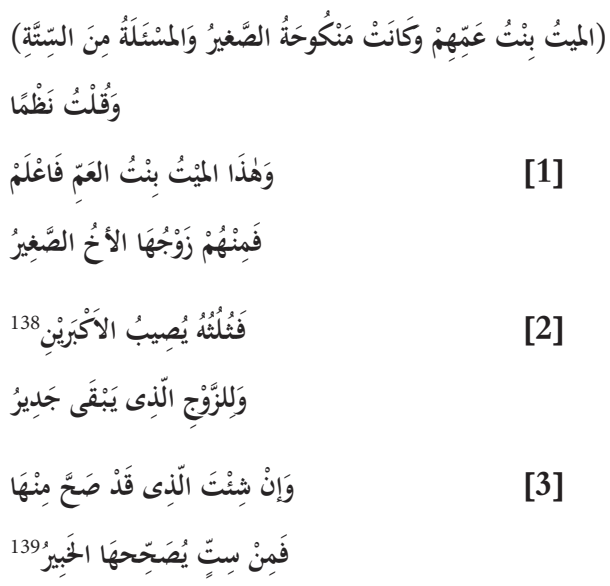

menin tamamlandığını belirten "son" kelimesi vardır. Cerîde-i Sûfiyye, nr. 132 (27 Safer 1336), s. 330. (Kemâleddin Efendi’nin Levâmic tercümesine başlarken yazdığı kıt'a için yk. bk. 32. dipnot, tercümeyi tamamladığında yazdığı diğer kıt’a için yk. bk. 128. dipnot.)

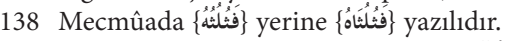

139 Nazzemehû Kemâleddin. Mecûma, AÜİF Kütüphânesi, Yazmalar Blm., nr. 38182, vr. $21^{\text {b }}$.

Bu lugaz, bazı ferâiz ve elgâz-ı fikhiyye kitaplarında şâiri belirtilmeden yer almaktadır. Fakīhlerin bu lugaze verdikleri bazı manzum cevaplar da söz konusu eserlerde bulunmaktadır. (bk. Abdülberr b. Muhammed İbnüşŞıhne, ez-Zehâirül'-eşrefiyye fi'l-elgâzi'l-fikhiyye [thk. Muhammed Adnân Dervîş], Dımaşk 1994, s. 187-188; Ebû Hakîm Abdullah b. İbrâhîm el-Habrî, Kitâbüt-telhîs fî ilmi'l-ferâiz [thk. Nâsır b. Fenhîr el-Ferîdî], Medine 1415, I, 158-159; Necmeddin Muhammed el-Gazzî̀, el-Kevâkibü's-sâire bi-a'yâni'l-mieti'l-âșire [thk. Halîl Mansûr], Beyrut 1997, II, 6.)

Lugazı ve lugazın hallini şöyle tercüme edebiliriz: 
$\underline{66}$

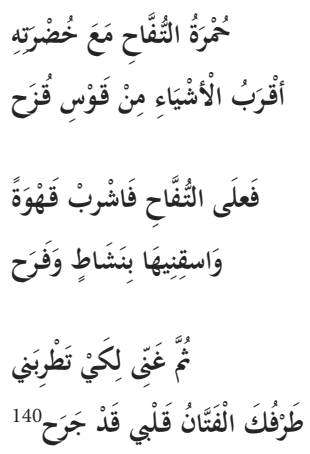

[1]

[2]

[3]

[Fâ'ilâtün (fe'ilâtün) fe'ilâtün fe'ilün (fa'lün)]

1. Humret ü hudreti ile tüffâh

Oluvermiş gibi bir kavs-i kuzah

\section{Elmanın üstüne iç kahveyi sen \\ Bana da sun vere gönlüme ferah}

\section{Lugaz:}

1) Ana-baba bir 3 erkek kardeş var. Hepsinin de mala-mülke ihtiyaçları bulunmakta.

2) Zamanın akıp geçmesi (ana-babanın vefâtı) onları mirasçı yaptı. Miras bırakanın da çok malı var.

3) İki büyük evlat mirasın 1/3’ünü aldı. Gerisi de küçüğe kaldı.

\section{[Cevâp:]}

(Vefât eden, amcalarının kızıdır. Bu kız küçük evlatla evliydi. Pay 6 üzerinden yapılır.)

\section{[Cevâbını] şöyle nazmettim:}

1) Vefât eden, kardeşlerin amcasının kızıdır, bilesin. Bu kadın aynı zamanda küçük kardeşin hanımıdır.

2) Mirasın 1/3’ü iki büyük kardeşe gider. Gerisi de kocaya (küçük kardeş) münâsip düşer.

3) Payın küsûrâtsız olmasını dilersen işin uzmanı(na danış, o) bunu 6 üzerinden yapar.

\begin{tabular}{|c|c|c|c|}
\hline \multicolumn{4}{|c|}{ Vârisler } \\
\hline Koca & Koca (Amcaoğlu) & Amcaoğlu & Amcaoğlu \\
\hline Aldığ 1 pay: $3(1 / 2=3 / 6)$ & $1(1 / 2 \times 1 / 3=1 / 6)$ & $1(1 / 6)$ & $1(1 / 6)$ \\
\hline \multicolumn{2}{|c|}{$\begin{array}{l}\text { Kocanın hem koca hem de amcaoğlu olarak } 6 \text { üzerinden aldığı toplam pay: } \\
4 / 6 \text { = Sülüsân } \\
\text { (Pay önce ikiye bölünür. Küçük evlat vefât eden kızın kocası olduğu için } \\
\text { kocalık payı olarak malın yarısını alır. Geriye kalan yarı da 3’e bölünür. Bu } \\
\text { üçten bir payı koca aynı zamanda amcaoğlu olduğu için alır. Geriye kalan } \\
\text { iki pay da eşit olarak ağabeylere kalır.) }\end{array}$} & \multicolumn{2}{|c|}{$\begin{array}{l}\text { Her iki amcaoğlunun aldıkları } \\
\text { pay } 1 / 6+1 / 6=\text { sülüs. }\end{array}$} \\
\hline
\end{tabular}

Lugazı doğru bir şekilde çözmem hususunda kıymetli yardımlarını esirgemeyen muhterem hocalarım Prof. Dr. Mehmet Erdoğan ve Prof. Dr. Hasan Hacak’a teşekkür ederim.

140 Bu beyitler Abbâsî halîfesi Me’mûn'un (v. 218/833) câriyelerinden birinin ona hediye ettiği bir elma ile birlikte yazıp gönderdiği mektupta yer almaktadır. Câriye mektupta halîfeye ilginç bir hediye vermekle onun dikkatini çekmek istediğini belirtmekte, elmanın özelliklerinden, doktorların, hakîmlerin ona dair söylediklerinden birkaç

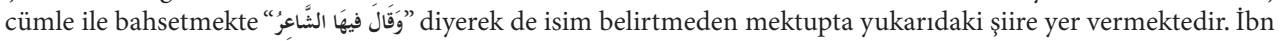
Abdürabbih, el-Ikdül-ferî́d (thk. Abdülmecîd et-Terhînî), Lübnan 1983, VII, 317-318. 
3. Beni nağmenle sevindir zîrâ

طَرْفُكَ الْفَتَانْ قَلْبي قَذْ جَرَح 141

67

[Mefầilün mefâ‘ilün mefâ‘ilün mefầilün]

1. Utan gönül! Yeter bırak sivâya meyl ü rağbeti

Zamânı geldi tevbe et Hudâya ver muhabbeti

2. Bu nâz ile hayâtını geçirme lu'b u lehv ile Çekersin âhiri ecel gelince çok nedâmeti

3. Hudâyya rabt-1 kalb edip sünûd-1 tâmma sa'y kıl Helâk eder seni birak bu hâbı ya'nî gafleti ${ }^{142}$

68

[Fâ'ilâtün fâ'ilâtün fâ‘ilâtün fâ‘ilün]

1. Âfiyetle yaşamak ister isen sen de bütün Çokça müşkildir fakat cehd et sakın içme tütün

2. Öyle azm et ki eğer boynun kesilse bir daha Bir nefes almak bile vermek gibi ola ...... ${ }^{143}$

3. Ey sebük-mağzân-1 millet dikkat ile dinleyin Tecrübemle sâbit oldu sözümü siz de tutun ${ }^{144}$

141 Li-nâzımihi'l-fakīr Muhammed Kemâleddin el-müftî bi-Ma'mûreti’l-azîz 'ufiye ‘anh. AÜİF Kütüphânesi, Yazmalar Blm., nr. 38182, vr. nr. yok. Arapça mısrâın vezni "fấilâtün fầilâtün fấilün” şeklinde.

142 Kemâleddin Efendi bu beyitleri Samsun'da iken kendisine Harput’tan gönderilen bir telgrafnâmenin arkasına yazmıștır. Telgrafnâme AÜİF Kütüphânesi, Yazmalar Blm., nr. 36’daki Mecmûa’da bulunmaktadır.

143 Kemâleddin Efendi kafiyeyi oluşturacak kelimeyi yazmamış, o kısmı noktalarla boş bırakmıştır.

144 Mütenevvi Duâ ve Nüshalar Mecmûası, AÜİF Kütüphânesi, Yazmalar Blm., nr. 89, arka kapak zahriyesi. 
g) Müfredler

69

[Fâ'ilâtün (fe'ilâtün) fe'ilâtün fe'ilâtün fâ'lün]

Zevk u gam tev'em imiş bak şu fenâ dünyâda

Pey-i vuslat[da] gelir firkat ü hicrân elbet ${ }^{145}$

70

[Mefấilün fe'ilâtün mefâ‘ilün fe'ilün]

Mehâsinim ki meâyib diye kabûl edilir

Beyân-1 ma'zeret içün aceb daha ne denir ${ }^{146}$

71

[Mef'îlü fầîlâtü mefầîlü fâ'ilün]

Borcum gelince 'aklıma her dem gözüm dolar

Rabbim meğer ki göndere bir haylice dolar ${ }^{147}$

$\underline{72}$

[Mefâ‘îlün mefâ‘îlün mefâ‘̂̂lün mefầîlün]

Rehâyâb olmaya âlâm u mihnetden bu dünyâda

Mekîn-i künc-i halvet olmadan eslem tarîk olmaz ${ }^{148}$

73

[Fe'îlün fe' ûlün fe' ûlün fe'ûl]

Hemân Hakk’a dön gâfil olma Kemâl

Sivâsı Hudânın hayâldir hayâl ${ }^{149}$

145 Mecmûa, AÜİF Kütüphânesi, Yazmalar Blm., nr. 36, s. 149.

146 Mecmûa, AÜİF Kütüphânesi, Yazmalar Blm., nr. 36143, vikāye varağ1.

147 Mecmûatül-Fetâvâ, AÜİF Kütüphânesi, Yazmalar Blm., nr. 37019 (vikāye varağı).

148 Mecmûa, AÜİF Kütüphânesi, Yazmalar Blm., nr. 36, s. 140.

149 a.g.e., s. 2. 
$\underline{74}$

[Fâ'ilâtün fầilâtün fầilün]

Elzem oldu sana kesb-i hüsn-i hâl

Girdi çünki altmışa sinnin Kemâl ${ }^{150}$

75

[Fe‘ilâtün fe‘ilâtün fe‘ilâtün fe‘ilün]

Tükenir mi kişide hâsıl olan tûl-1 emel

Ma'rifet kurmamadır hırsa tamâmıyla temel ${ }^{151}$

$\underline{76}$

[Mef' ûlü mefầîlü mefâ‘̂̂lü fe ûlün]

Rü'yâ gibidir 'ayn-1 hakīkatde bu âlem

Lâzım ki uyanık ola Hakk’ı bula âdem ${ }^{152}$

77

[Mef'îllü mefầîlü mefâ‘̂̂lü fe'ûlün]

Hak Hak diye feryâd ediver Hakk'ı unutma

Dikkatli bulun âkil isen gafleri yutma ${ }^{153}$

$\underline{78}$

[Fe'ilâtün fe'ilâtün fe'ilâtün fe'ilün]

Cebel-i Tûr'a da varsan arama dur orada

Nerede vech-i hasen varsa hemân Tûr orada ${ }^{154}$

150 a.g.e., s. 2.

151 Li-muharririhî Kemâleddin el-fakïr. a.g.e., s. 149.

152 Nâzımuhû Kemâleddin ufiye anh. Mütenevvi` Duâ ve Nüshalar Mecmûası, AÜİF Kütüphânesi, Yazmalar Blm., nr. 89, vr. nr. Yok; Mecmûa, AÜİF Kütüphânesi, Yazmalar Blm., nr. 38182, vr. nr. yok.

153 Mecmûa, AÜİF Kütüphânesi, Yazmalar Blm., nr. 36, s. 3.

154 Kemâleddin Efendi’nin imzalarının olduğu varakta kayıtlı bulunan bu beyti başka kaynaklarda rastlayamadığımız için buraya yazdık. Osmanlı imlasında "Tûr" ile "dur”" aynı harflerle yazıldığı için ikinci mısrâ iki türlü okunmaya müsâittir. (Mecmûa, AÜİF Kütüphânesi, Yazmalar Blm., nr. 38182, vr. nr. yok.) 
79

[Fâ'ilâtün fầilâtün fầilün]

Kendi cürmümdür yıkan mutlak beni

Sanma haksız etti rüsvâ Hak beni ${ }^{155}$

80

[Fâ'ilâtün fe'ilâtün fâ‘lün]

Kimsenin kimseye yokdur hayrı

Sevme bir kimseyi Hak'dan gayrı ${ }^{156}$

81

[Fâ'ilâtün fâ‘ilâtün fâcilâtün fâ‘ilün]

Eyledim kavl-i Fuzûli'yle muhâtab ben seni

"Sûret-i hâlim gören sûret hayâl eyler beni" 157

$\underline{82}$

[Mefâ‘îlün mefầîlün fe'ûlün]

Kemâlin ber-kemâldir hüsn-i zannı

158151

155 Mecmûa, AÜİF Kütüphânesi, Yazmalar Blm., nr. 36, s. 153.

156 Kemâl. a.g.e., s. 2.

157 Mecmûa, AÜİF Kütüphânesi, Yazmalar Blm., nr. 38182, vr. nr. yok. Kemâleddin Efendi’nin tazmîn ettiği mısrâ Fuzûlînnindir. (bk. Fuzûlî, Dîvân, İstanbul 1268, s. 81.)

158 Kemâleddin ufiye anh. Mütenevvi` Duâ ve Nüshalar Mecmûası, AÜİF Kütüphânesi, Yazmalar Blm., nr. 89 , s. 343. 


\section{Kaynaklar}

\section{Yazma Eserler}

ed-Dimyâtî, Muhammed b. Muhammed Ahmed el-Büdeyrî, el-Cevâhirü'l-ğavâlî fî zikri'l-

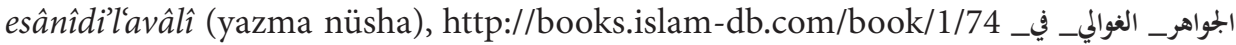
ذكر_ الأسانيد_ العوالي للبديري _ مخطوط

Kemâleddin Harputî, Mütenevvi` Duâ ve Nüshalar Mecmûası, AÜİF Kütüphânesi, Yazmalar Blm., nr. 89.

, Tesbîtül-mefhûm fî tahkiki’t-tebe'iyyeti beyne'l-'ilmi ve'l-ma'lûm, AÜDTCF Kütüphânesi, Mustafa Con Blm., nr. A/237.

Mecmûa, AÜİF Kütüphânesi, Yazmalar Blm., nr. 25.

Mecmûa, AÜİF Kütüphânesi, Yazmalar Blm., nr. 36.

Mecmûa, AÜİF Kütüphânesi, Yazmalar Blm., nr. 36143.

Mecmûa, AÜİF Kütüphânesi, Yazmalar Blm., nr. 38182.

Mecmûa, Atatürk Kitaplı̆̆

Mecmûatü'l-Fetâvâ, AÜİF Kütüphânesi, Yazmalar Blm., nr. 37019.

Süyûtî, el-Câmi'u’s-sağîr, AÜİF Kütüphânesi, Yazmalar Blm., nr. 36447.

\section{Eski Harfli Gazeteler-Dergiler}

Beyânül-Hak

Cerîde-i Sûfiyye

Hazîne-i Fünîn

I'tisâm

Takvîm-i Vekāyî

Tercümân-ı Hakikat

\section{Diğer Matbû Eserler}

Abdullah Ammârî, Muhammed b. Übbe'l-Müzzemmirî el-Cezâirî et-Tevâtî ve cühûduhû finnahvi, yüksek lisans tezi, 2010, Cezâyir Kasdi Merbah-Ouargla Üniversitesi, Dil ve Edebiyat Fak. Arap Dili ve Edebiyatı Blm.

Abdülberr b. Muhammed İbnü’ş-Şıhne, ez-Zehâirü'l-eşrefiyye fi'l-elgâzi'l-fikhiyye (thk. Muhammed Adnân Dervîş), Dimaşk 1994.

Abdülvehhâb eş-Şa'rânî, et-Tabakātü'l-kübrâ (thk. Ahmed Abdurrahîm es-Sâyih-Tevfîk Ali Vehbe), I-II, Kahire 2005. 
Acer, Abdurrahman, Mesnevîhân Ali Fuâd Efendinin Cerîde-i Sûfiyye’deki Makāleleri, yüksek lisans tezi, 2011, Marmara Üniversitesi SBE.

Aclûnî, Keşfüll-hafâ ve müzîlü'l-libâs ammâ iştehera mine’l-ehâdîsi 'alâ elsinetin-nâs, I-II, Beyrut 1351.

Ahmed b. Hanbel, el-Müsned (thk. Ahmed Muhammed Şâkir- Hamza Ahmed ez-Zeyn), I-XX, Kahire 1995.

Ahmed Bâdî Efendi, Riyâzz-ı Belde-i Edirne (haz. Niyazi Adıgüzel-Raşit Gündoğdu), I-II, İstanbul 2014.

Ahmed Ebü’s-Sâfî Ca'ferî, Muhammed b. Übbe'l-Müzzemmirî hayâtuhu ve âsâruhu, Cezâyir 2004.

Aksoyak, İsmail Hakkı, Gelibolulu Mustafa Âlìnin Divanları, I-II, Harvard University 2006.

Akün, Ömer Faruk, “İbnülemîn Mahmud Kemâl”, DİA, İstanbul 2000, XXI, 249-262.

Ata, Ferudun, İsgal İstanbulunda Tehcir Yargılamaları, Ankara 2005.

Ateş, Süleyman, Bir Ömür Böyle Geçti, I-II, İstanbul ty.

Ayaz, Hayrettin, Dîvân: Harputlu Abdülhamid Hazmî̀, İstanbul 1998.

Aybakan Bilal, “İbnü'l-Vekîl”, DİA, İstanbul 2000, XXI, 237-238.

Aydoğmuş, Günerkan, Harput Kültüründe Din Âlimleri, Elazı̆̆ 1998.

Buhârî, Ebû Abdillâh Muhammed b. İsmâîl b. İbrâhîm el-Cu'fî, el-Câmiu’s-sahîh (thk. Takıyyüddîn en-Nedvî), I-XV, Beyrut 2011.

Bursalı Mehmed Tâhir, Osmanlı Müellifleri, I-III, İstanbul 1342.

Can, Şefik, Hz. Mevlânầnın Rubâileri, Ankara 2001.

Celâleddin Süyûtî, Kitâbü Buğyeti'l-vu'ât fî tabakāti'l-lügaviyyîn ve’n-nuhât (thk. Muhammed Ebü'l-fazl İbrâhîm), I-II, Lübnan 1979.

Çöl, Bekir, “Buluntu Cönk”, https://sivasbekircol.wordpress.com/2011/05/15/buluntu-conk.

Dîvânu Ebü'l-Atâhiyye, Beyrut 1886.

Dîvânu’n-Nâbiğatü'z-Zübyânî (thk. Muhammed Ebü'l-fazl İbrâhîm), Kahire 1985.

Dîvânu'n-Nâbiğatü'z-Zübyânî, Misir 1911.

Dîvânü Ebî Nüvâs, Kâhire 1898.

Ebû Hakîm Abdullah b. İbrâhîm el-Habrî, Kitâbü't-telhîs fî ilmi'l-ferâiz (thk. Nâsır b. Fenhîr el-Ferîdî), I-II, Medine 1415.

Ebû Yakub Yusuf b. Tahir Huveyyî, Ferâidü'l-harâid fi'l-emsâl (thk. Abdurrezzâk Huseyn), Ürdün ty.

Ebü’l-Hüdâ Muhammed b. Hasan Vâdî b. Ali Sayyâdî, Kılâdetü’l-cevâhir fî zikri'l-gavsir-Rifâ‘̂ ve etbâ'ihi'l-ekâbir, Beyrut 1301. 
ed-Dârânî, Selâhaddin Muhammed b. Şakir el-Kütübî, Fevâtü'l-vefeyât, I-II, yy., 1282.

el-Âlûsî, Ebü’l-ma âlî Mahmûd Şükrî, Gâyetü'l-emânî fi'r-reddi 'ale’n-Nebhânî, I-II, Riyad 2001.

el-Alûsî, Şihâbüddin Seyyid Mahmûd, Rûhu'l-me'ânî fî tefsîrill-Kur'âni'l-'azîm ve’s-seb'u'lmesânî, I-XXX, Beyrut ty.

el-Âmilî, Bahâüddîn Muhammed b. Hüseyn b. Abdissamed, el-Keşkûl (thk. Muhammed Abdülkerim en-Nemrî), I-II, Beyrut 1998.

el-Hafâcî, Ahmed b. Muhammed b. Ömer Şihâbüddin, 'Inâyetül-Kādî ve kifâyetü’r-Râzî 'alâ Tefsîri'l-Beyzâvî (Hâşiyetüş-Şihâb 'alâ Tefsîri'l-Beyzâvî), I-VIII, Kahire 1283.

— , Dîvân, yy., ty. , Tirâzu’l-Mecâlis, Kahire 1284.

el-Meydânî en-Nîsâbûrî, Ebü'l-fazl Ahmed b. Muhammed, Mecma'u'l-emsâl (thk. Muhammed Muhyiddin Abdülhamîd), I-II, Beyrut 1972.

Ergin, Ali Şâkir, “Hafâcî”, DİA, İstanbul 1997, XV, 72-73.

es-Safedî, Salâhaddin Halîl b. Aybek, Kitâbü'l-vâfî bi'l-vefeyât, I-XXX, Beyrut 2000-2004.

Etker, Şeref, “Ophtalmoscope Essad”, Osmanlı Bilimi Araştırmaları, IX/1-2 (İstanbul 20072008), s. 151-164.

et-Turtûşî, Ebû Bekr Muhammed b. Velîd, Sirâcü'l-mülûk, İskenderiyye 1289.

ez-Zehebî, Şemseddin Ebû Abdillâh Muhammed b. Ahmed b. Osmân, Târîhu'l-İslâm ve vefeyâti'l-meşâhîri ve’l-a lâm (thk. Beş̧̧âr Avvâd Ma'rûf), I-XV, Beyrut 2003.

Fatin Dâvûd, Hâtimetü’l-eşâr (haz. Ömer Çiftçi), Ankara ty.

Fuzûlî, Dîvân, İstanbul 1268.

Güner, Ahmet, “İbnü’l-Amîd”, DİA, İstanbul 1999, XX, 485-486.

Hasan Muhammed Şeddâd, el-Kevkebü's-sấî fî tercemeti ve sîreti seyyidî Ahmed er-Rifấ $\hat{\imath}$, Beyrut 2013.

Hersekli Ârif Hikmet: Külliyât-ı Âsâr 1: Dîvân (nşr. İbnülemîn Mahmud Kemâl), İstanbul 1334.

Hüseyin Vassâf, Gülzâr-ı Aşk (haz. Mustafa Tatcı ve dgr.), İstanbul 2006.

, Kemâlü'l-Kemâl: Bir Eski Zamân Efendisi İbnülemîn Mahmud Kemâl (haz. Fatih M. Şeker-İsmail Kara), İstanbul 2009.

http://makrim.org/manuscrits.cfm?PN=282.

http://www.taouat.net/main/index.php/2014-10-23-10-10-09/45-2011-01-23-10-1452/321-1160.

İbn Abdürabbih, el-Ikdü'l-ferîd (thk. Abdülmecîd et-Terhînî), I-IX, Lübnan 1983. 
İbn Hacer el-Askalânî, İthâfüll-mehere, I-XIX, Medîne 1999.

İbn Hicce el-Hamevî, Hizânetü'l-edeb ve gâyetü'l-ereb, Kahire 1291.

İbn Mâce, Ebû Abdillâh Muhammed b. Yezîd Mâce el-Kazvînî, es-Sünen, I-II, Riyâd 1986.

İbn Manzûr, Lisânü'l-Arab, I-XVIII, Beyrut 1999.

İbnü'l-İmâd, Şezerâtü'z-zeheb fî ahbâri men zeheb (thk. Abdülkādir el-Arnaut-Mahmûd elArnaut), I-X, Beyrut 1993.

İmam Efendi, Osman Bedreddin Erzurumî, Gülzâr-ı Sâminî: Sohbetler, İstanbul 1993. , Gülzâr-ı Sâminî: Mektûbât, I-II, İstanbul 2006.

İmam Rabbânî, ed-Dürerü’l-meknûnâtìn-nefîse, İstanbul 2002.

İnal, İbnülemîn Mahmud Kemâl, Son Asır Türk Şâirleri, I-IV, İstanbul 1988.

İsmâil Rusûhî Ankaravî, Șerhu’l-Mesnevî, I-VI, Bulak 1289.

Karataş, Ahmet, "Harput Ulemâsından Müderris-Müftü Mehmed Kemâleddin Efendi", Marmara Üniversitesi İlâhiyat Fakültesi Dergisi, sy. 49 (İstanbul 2015), s. 29-125.

, "Harput Ulemâsından Müderris-Müftü Mehmed Kemâleddin Efendi’nin Rekāik: Hadîs-i Erbaîn Risâlesi”, Marmara Üniversitesi İlâhiyat Fakültesi Dergisi, sy. 48 (İstanbul 2015), s. 57-94.

Karayel, Gabriele, The First Six Editions of Ceride-i Sufiyye (19th March, 1909-2nd May, 1909) or Sufism as a Metaphor, yüksek lisans tezi, 1990, Boğaziçi Üniversitesi SBE.

Kaşıkçı, Atilla, Bütün Yönleriyle Cerîde-i Sûfiyye, yüksek lisans tezi, 1994, Dicle Üniversitesi SBE.

Kemâledin Harputî, Kasîde-i Münferice’nin Tahmîsiyle Berâber Türkçe Şerhidir, Ma'mûretü’lazîz 1317.

Keskinbora, H. Kadircan, Bilimde, Siyasette, Milli Mücadelede Bir Iş̧ı: Esat Işık, İstanbul 2010. , Mehmet Esat Işık Paşa: Hayatı Tip Tarihimizdeki ve Türk Oftalmoloji Tarihindeki Yeri ve Katkıları, (doktora tezi, 2006), İstanbul Üniversitesi Sağlık Bilimleri Enstitüsü.

Kıyak, Abdulkadir, Elazığ ve Yöresinde Ziyaret Fenomeni Üzerine Bir Din Bilimi Araştırması, (doktora tezi, 2010), Erciyes Üniversitesi Sosyal Bilimler Enstitüsü.

Kurnaz, Cemal, "Sırrı Paşa”, DİA, İstanbul 2009, XXXVII, 127-129.

Kurnaz, Cemal -Tatc1, Mustafa, "Hüseyin Vassâf”, DİA, İstanbul 1999, XIX, 18-19.

Kütükoğlu, Bekir- Akün, Ömer Faruk, “Âlî Mustafa Efendi”, DİA, İstanbul 1989, II, 414-421.

Mecdüddin Ebû Abdillâh el-İrbilî, Dîvânu İbnizz-Zahîr el-İrbilî, yy., ty.

Mehmed Nâzım Paşa, Muhâtaba, I-II, Kostantiniyye 1316.

Mehmed Süreyyâ, Sicill-i Osmânî, I-IV, İstanbul 1311.

Memişoğlu, Fikret, “Elazığ’da Basın Hayatı", Yeni Firat, sy. 22 (İstanbul 1964), s. 21-26. 
Mevlânâ Celâleddin Rûmî, Külliyât-ı Şems (haz. Bedîuzzamân Fürûzanfer), Tahran 1342.

Muallim Nâcî, Muallim, İstanbul 1303. , Yazmış Bulundum, İstanbul 1301.

Muhammed Veysü'l-Hayderî, ed-Dürerü'l-behiyye fil-ensâbil-Hayderiyye ve’l-Üveysiyye, Halep 1405.

Müslim, Ebü'l-Hüseyn Müslim b. el-Haccâc b. Müslim el-Kuşeyrî, el-Câmi'u's-sahîh, I-II, Riyâd 2006.

Necmeddin Muhammed el-Gazzî, el-Kevâkibü's-sâire bi-a'yâni'l-mieti’l-âşsire (thk. Halîl Mansûr), I-III, Beyrut 1997.

Nizâmî, Mahzenü'l-esrâr (haz. Hasan Vâhid Destgirdî), Tahran 1343.

Onur, M. Naci, Harputlu Dîvân Şâirleri, Elazığ [1988].

Ömer Rızâ Kehhâle, Mu'cemü'l-müellifîn, I-IV, Beyrut 1993.

Öngören, Reşat, “Sühreverdiyye”, DİA, İstanbul 2010, XXXVIII, 42-45.

Özgül, M. Kayahan, Hersekli Ârif Hikmet, Ankara 1987.

Sâlih b. Mukbil el-Asîmî et-Temîmî, el-Vicâze fî istismâri'l-vakti ve’l-icâze, Riyad, ty.

Sayı, Hasan Basri, Osmanlı Belgeleri Işı̆̆̆ında Dr. Esat Bey’in Biyografisi ve Görme Engellilere Yönelik Ĕ̆itim Çalışmaları, yüksek lisans tezi, 2008, Selçuk Üniversitesi, Sosyal Bilimler Enstitüsü.

Sunguroğlu, İshak, Harput Yollarında, I-IV, İstanbul 1958-1968.

Şükrî Faysal, Ebü’l-Atâhiyye eşâ̂ruhu ve ahbâruhu, Kahire 1965.

Taberânî, el-Mu'cemü'l-evsat (thk. Târık b. Avdullâh b. Muhammed-Abdü'l-muhsin b. İbrâhîm el-Hüseynî), I-X, Kahire 1995. , el-Mu'cemü'l-kebîr (thk. Hamdî Abdülmecîd es-Selefî), I-XV, Beyrut 1984.

Tansel, Fevziye Abdullah, "Muallim Nâci ile Recâizâde Ekrem Arasındaki Münâkaşalar ve Bu Münâkaşaların Sebep Olduğu Edebî Hâdiseler”, Türkiyat Mecmuası, X (İstanbul 1953), 159-200.

Tehânevî, Zafer Ahmed Sahib, el-Bünyânü'l-müşeyyed, Karaçi 1325.

Tirmizî, Ebû Îsâ Muhammed b. Îsâ b. Sevre, el-Câmi'u’s-sahîh (thk. Abdullah b. Abdulkādir et-Tancî), I-III, Beyrut 2015.

Yarar, Necmeddin Rıfat - Ünver, A. Süheyl, Müderris Doktor ve Göz Mütehassısı Esad "Işık” Paşa, İstanbul 1972.

Yılmaz, Hasan Kâmil, “Sühreverdî”, DİA, İstanbul 2010, XXXVIII, 40-42. 
Ekler: Kemâleddin Efendi’nin şiirlerinden örnek metinler:

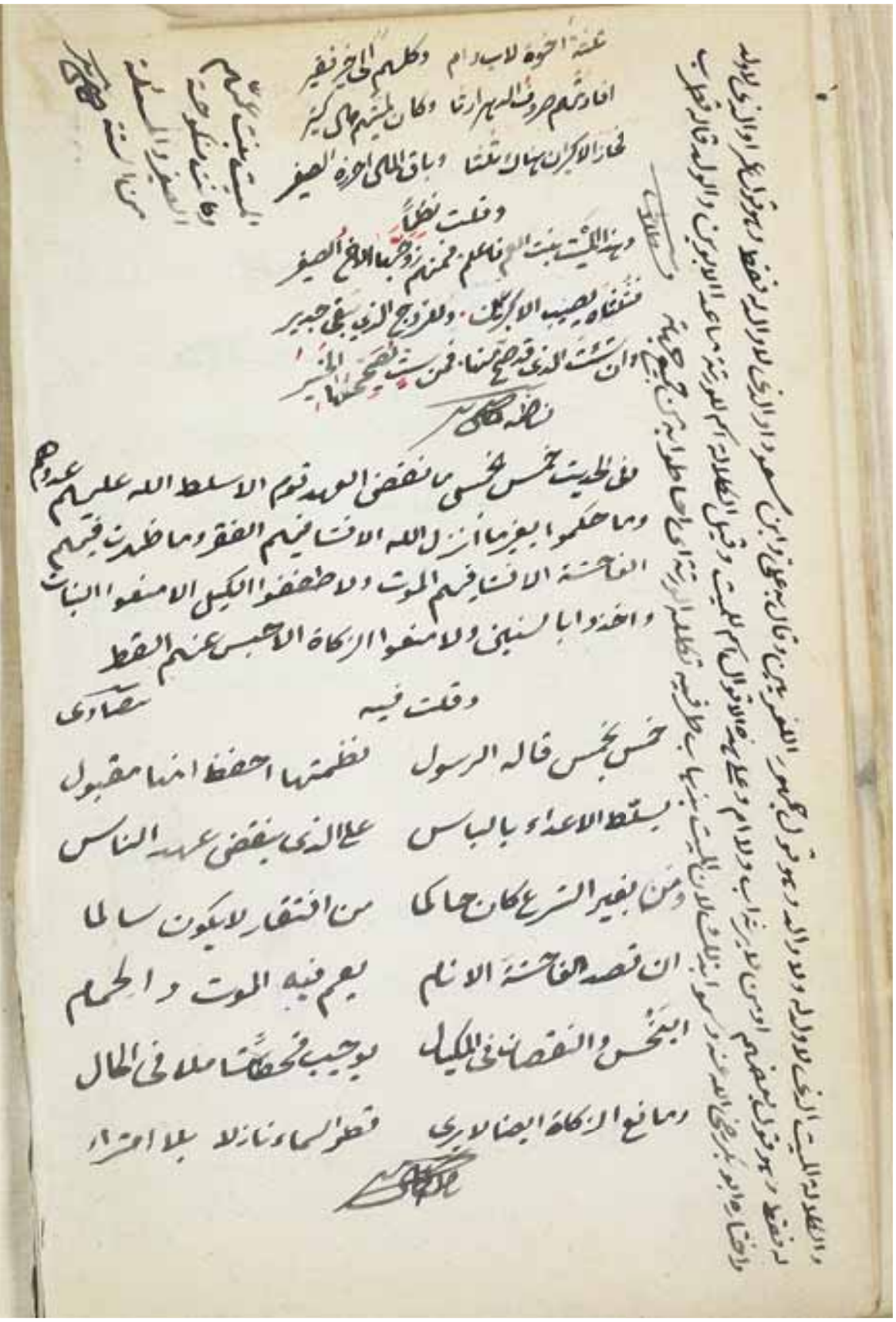

Mecmûa, AÜİF Kütüphânesi, Yazmalar Blm., nr. 38182, vr. nr. yok. 


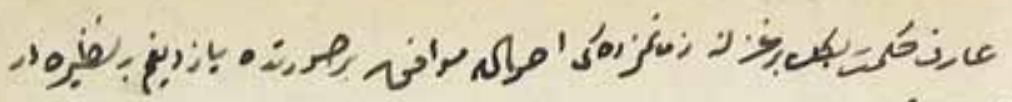

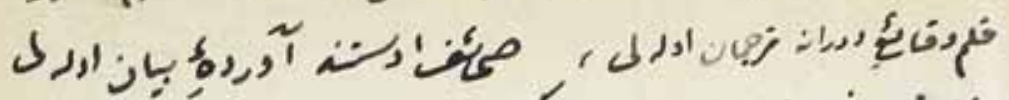

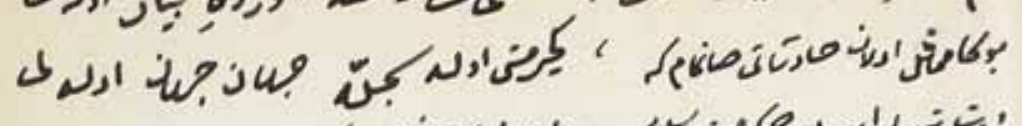

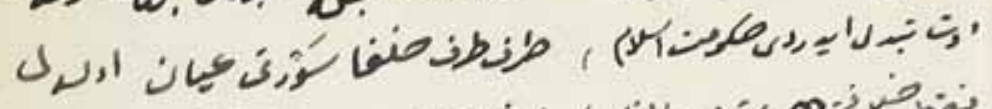

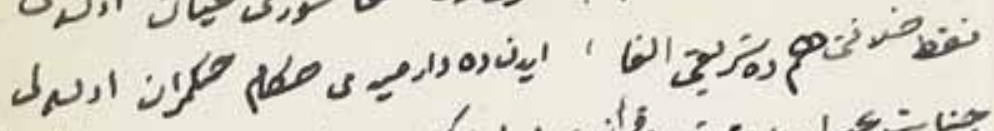

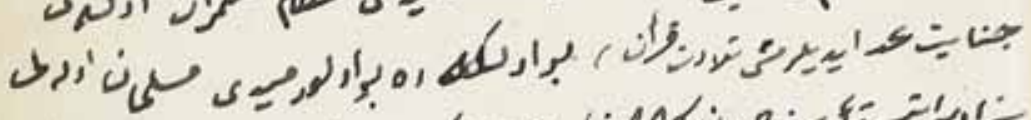

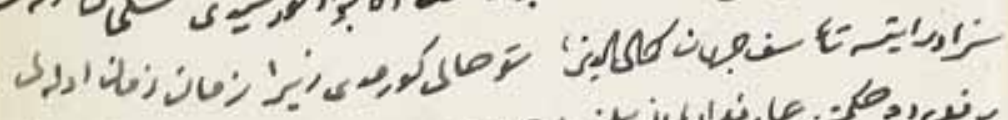

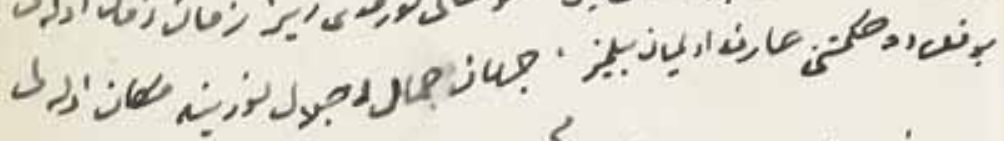

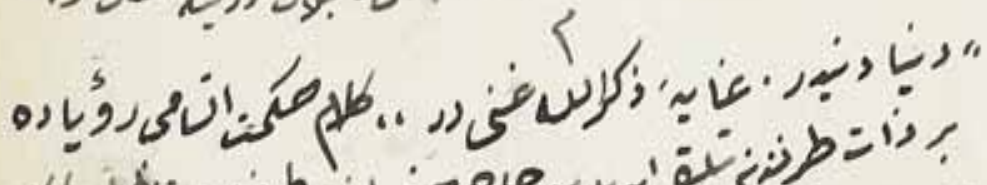
"ع

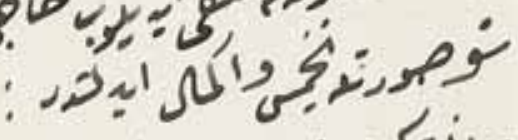

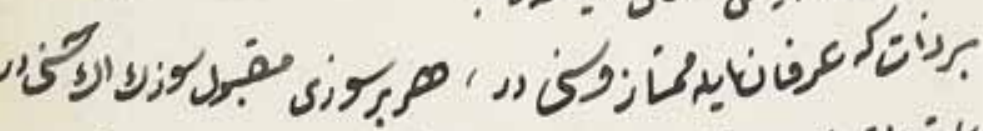

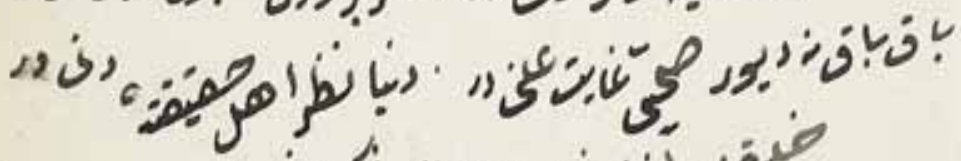

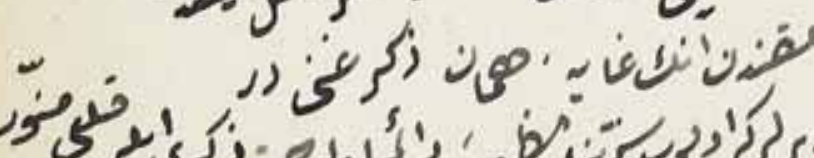

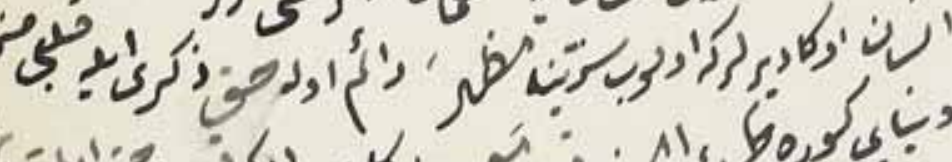

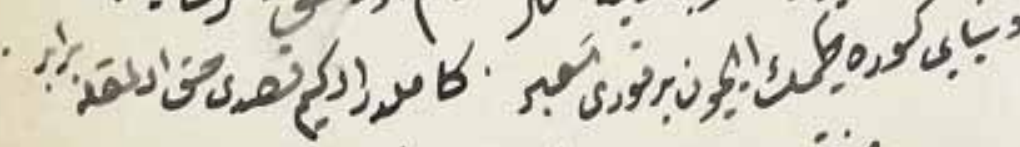

$$
\text { " }
$$

Mecmûa, AÜİF Kütüphânesi, Yazmalar Blm., nr. 38182, vr. nr. yok. 